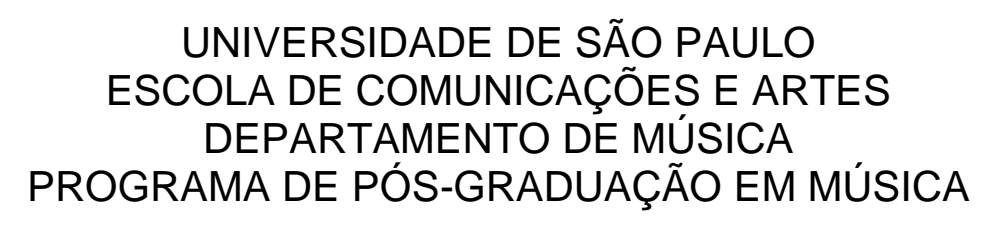

ADRIANA MORAES DOS SANTOS DIAS

PRÁTICAS DOCENTES E O ALUNO ADULTO INICIANTE DE PIANO 


\section{PRÁTICAS DOCENTES E O ALUNO ADULTO INICIANTE DE PIANO}

Dissertação apresentada ao Programa de PósGraduação em Música, da Escola de Comunicações e Artes da Universidade de São Paulo como exigência parcial para obtenção do título de Mestre em Música.

Área de Concentração:

Processos de Criação Musical.

Orientador: Prof. Dr.

Marcos Câmara de Castro.

São Paulo 
Autorizo a reprodução e divulgação total ou parcial deste trabalho, por qualquer meio convencional ou eletrônico, para fins de estudo e pesquisa, desde que citada a fonte.

FICHA CATALOGRÁFICA

Dias, Adriana Moraes dos Santos

Práticas docentes e o aluno adulto iniciante de piano / Adriana Moraes dos Santos Dias; orientador Prof. Dr. Marcos Câmara de Castro. - São Paulo, 2016.

100 p. : il.

Dissertação (Mestrado) - Universidade de São Paulo, 2016

1. Ensino de piano. 2. Adulto. 3. Aprendizagem de piano.

4. Criatividade. 5. Educação musical. 
DIAS, Adriana Moraes dos Santos

Práticas docentes e o aluno adulto iniciante de piano

Dissertação apresentada ao Programa de PósGraduação em Música, da Escola de Comunicações e Artes da Universidade de São Paulo como exigência parcial para obtenção do título de Mestre em Música.

Aprovado em:

Banca Examinadora

Prof. Dr. Instituição:

Julgamento: Assinatura:

Prof. Dr. Instituição:

Julgamento: Assinatura:

Prof. Dr. Instituição:

Julgamento: Assinatura: 
À minha amada e saudosa mãe, Marlene Moraes (in memoriam), pelos mais belos ensinamentos que guardarei por toda a vida. 


\section{AGRADECIMENTOS}

A Deus;

Ao Prof. Dr. Marcos de Câmara Castro, professor da Universidade de São Paulo, por acreditar na importância do tema aqui apresentado e pelos momentos valiosos de orientação e incentivo durante todo o percurso da pesquisa;

Aos meus pais Walter e Marlene (in memoriam), pelo apoio incondicional desde a minha iniciação ao piano;

Ao meu esposo Jesualdo Dias, por seu amor e pela carinhosa compreensão, tão necessária na minha dedicação à pesquisa;

À minha amiga irmã Gisele Haddad, professora da Universidade de Ribeirão Preto, pela amizade, apoio e por compartilhar comigo suas experiências;

Aos professores e alunos de piano da cidade de Ribeirão Preto que, gentilmente, aceitaram participar desta pesquisa;

À Profa. Dra. Fátima Monteiro Corvisier e Profa. Dra. Maria Teresa de Alencar Brito, professoras da Universidade de São Paulo, por participarem da banca e pelas significativas considerações apresentadas na qualificação;

À Profa. Dra. Andrea M. Marcaccini, professora da Universidade de Ribeirão Preto, pelas conversas acerca da pesquisa;

Ao Prof. Dr. Alberto Tsuyoshi Ikeda, professor da Universidade Estadual Paulista "Júlio de Mesquita Filho", pelas importantes contribuições metodológicas durante as aulas da disciplina "Metodologia da pesquisa em música", sendo professor convidado pela Escola de Comunicações e Artes da Universidade de São Paulo;

À minha querida amiga Cíntia e sua família, pela acolhida em sua casa;

Aos meus alunos, por me levarem à pesquisa e à reflexão;

Aos amigos e colegas de profissão que encontrei durante a caminhada do mestrado;

À minha querida família, pelos momentos de apoio e amizade;

A todos, a minha gratidão. 
Eu gostaria de fazer um desafio. A alegria de estudar música deve ser oferecida a todas as pessoas. O que eu estou realmente querendo dizer agora é a respeito de música para todas as idades - do berço à sepultura - do útero ao túmulo (HOFFMAN, 1980 apud MEDEIROS, 1998, p. 3). 


\section{RESUMO}

DIAS, A. M. S. Práticas docentes e o aluno adulto iniciante de piano. 2016. 100f. Dissertação (Mestrado) Escola de Comunicações e Artes, Universidade de São Paulo, São Paulo, 2016.

O processo de ensino e aprendizagem de piano na fase adulta apresenta diversos desafios para o professor e o aluno. Em meu percurso musical como professora de piano, com foco para o aluno adulto, questões surgiram e trouxeram-me inquietações que me levaram à pesquisa e à reflexão sobre as práticas docentes em relação ao aprendizado do aluno iniciante. Tais questões estão relacionadas aos aspectos da pessoa adulta e à aprendizagem pianística, bem como os modos de condução dos conteúdos musicais e dos tipos de materiais didáticos (métodos e tipos de repertório) utilizados pelos professores do instrumento. A partir disso, essa dissertação propõe uma reflexão sobre a prática do ensino e aprendizagem para alunos adultos iniciantes no piano em aulas particulares, em escolas livres de música e em conservatórios, na cidade de Ribeirão Preto. Como referencial teórico, destacam-se os aspectos de aquisição de habilidades pianísticas, de Kaplan (1996), e as relações de aprendizagem do aluno adulto e o estudo de piano, de Bastien (1973), Stateri (1996, 2014), Uszler (2000), Sahr (2004) e Jacobson (2006). Nesse contexto específico, aponta-se a relevância da presença de atividades criativas, através das ideias de Campos (2000). Esse estudo abarca, ainda, uma breve análise de seis materiais de iniciação ao piano, voltados para adultos. Além da revisão teórica acerca do tema, onze professores que atuam no ensino de piano para alunos adultos e cinco alunos adultos iniciantes de piano fazem parte desse estudo. As respostas dos participantes foram coletadas através de entrevistas e questionários. Elas apresentam aspectos importantes acerca do tema e apontam para a necessidade de elaboração de propostas de ensino de piano que incorporem as especificidades do público adulto. As reflexões aqui apresentadas buscam contribuir para a área que trata dos processos de ensino e aprendizagem de música e do ensino do piano.

Palavras-chave: Ensino de piano. Adulto. Aprendizagem de piano. Criatividade. Educação musical. 


\begin{abstract}
DIAS, A. M. S. Teaching practices and the adult beginner student of piano. 2016. 100f. Dissertação (Mestrado) Escola de Comunicações e Artes, Universidade de São Paulo, São Paulo, 2016.

The learning and the teaching process of piano in adulthood presents many challenges for the teacher and student. In my musical career as a piano teacher with focus on the adult learner, questions have been raised and brought me concerns that led me to research and to reflection on teaching practices regarding the beginner student. Such issues are related to aspects of adulthood and to the piano learning, as well as the ways of conducting the musical content and the types of teaching materials (methods and types of repertoire) used by instrument teacher. From this, this dissertation proposes a reflection about the practice of teaching and learning for beginners adult students in piano private lessons, music free schools and conservatories in the city of Ribeirao Preto. As a theoretical reference we highlight the Kaplan's about of acquiring pianistic skills (1996), the Bastien's learning conections of the adult learner and the piano study (1973), Stateri (1996, 2014), Uszler (2000), Sahr (2004) and Jacobson (2006). In this particular context, it points out the relevance of the presence of creative activities, through the Campos's ideas (2000). This study includes also a brief analysis of six piano beginners materials, aimed at adults. In addition to the literature review on the topic, are part of this study eleven teachers who work in piano teaching for adult students, also five piano beginners adult learners. The answers of the participants were collected through interviews and surveys. They present important aspects about the theme and point to the need for development of piano teaching proposals that incorporate the specifics of adult audience. The reflections presented here seek to contribute to the area that deals with the processes of teaching and learning music and piano teaching.
\end{abstract}

Keywords: Piano teaching. Adult. Piano learning. Criativity. Musical education. 


\section{LISTA DE QUADROS}

Quadro 1- Aspectos comparativos entre adultos e crianças no processo de aprendizagem

Quadro 2- Perfil dos alunos participantes da pesquisa 49

Quadro 3- Perfil dos professores participantes da pesquisa .49

Quadro 4- Relação professor e locais de atuação 60

Quadro 5- Motivações dos alunos descritas pelos docentes 62

Quadro 6- Relação método pianístico e aluno 69

Quadro 7- Relação método pianístico e professor .70

Quadro 8- Repertórios escolhidos pelos alunos adultos de piano 72

Quadro 9 -Elementos favoráveis e não favoráveis na aprendizagem do piano por alunos adultos 


\section{LISTA DE TABELAS}

Tabela 1- Métodos de piano para crianças e suas indicações

Tabela 2- Métodos de piano para alunos adultos e suas indicações 72 


\section{LISTA DE ABREVIATURAS E SIGLAS}

IBGE

Instituto Brasileiro de Geografia e Estatística

TCLE

Termo de Consentimento Livre e Esclarecido

ULM

Universidade Livre de Música

UNAERP

Universidade de Ribeirão Preto

UNESP

Universidade Estadual Paulista "Júlio de Mesquita Filho"

UNESCO

Organização das Nações Unidas para a Educação, a Ciência e a Cultura

USP

Universidade de São Paulo 


\section{SUMÁRIO}

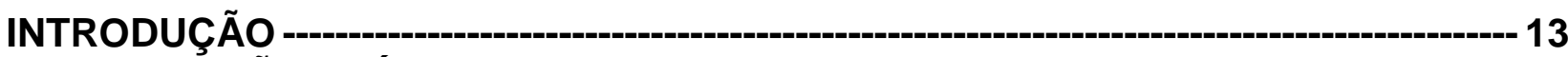

1 APRECIAÇÃO CRÍTICA DA LITERATURA -

$1.1 \mathrm{O}$ adulto --o

1.20 aluno adulto de piano -- 20

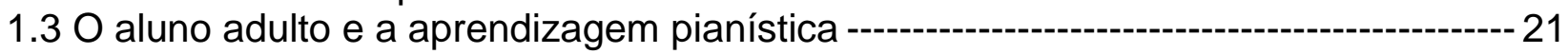

1.4 A aprendizagem de piano e criatividade --

1.5 Métodos de iniciação pianística para adultos --------------------------------- 29

1.5.1 Adult Piano Course - Book One, Preparatory (THOMPSON, 1943)---------- 31

1.5.2 The older beginner piano course - Level 1 (BASTIEN, 1977) ------------ 33

1.5.3 Tocar piano1: Iniciação para adultos (CURY; THIELE, 1997) -------------- 34

1.5.4 Toque piano hoje ...e sempre: curso de piano para adultos (BUCHER, 2009) 36

1.5.5 Adult Piano Adventures - A comprehensive piano course (FABER; FABER,

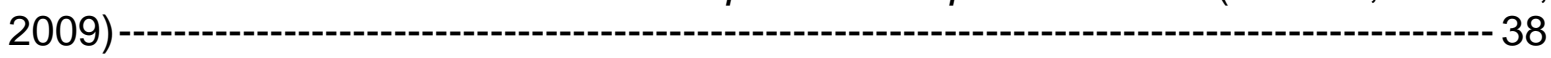

1.5.6 Upper Hands - A Method for Adults 50+ (SCHOEN, 2012) --------------- 40

1.5.7 Dos métodos--- $A M$

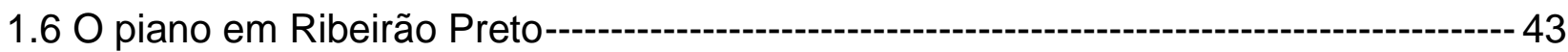

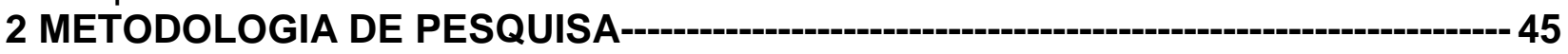

2.1 Metodologia Qualitativa---- 45

2.2 Seleção e delimitação dos sujeitos entrevistados ----------------------- 47

2.3 Os instrumentos de coleta de dados: entrevistas e questionários -------.------- 48

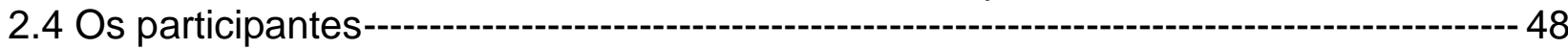

2.5 Forma de Análise --- 49

3 SOLILÓQUIOS E DIÁLOGOS NO PROCESSO DE ENSINO E APRENDIZAGEM DE

PIANO NA FASE ADULTA - 51

3.1 Trajetória Musical--- 51

3.1.1 Dos alunos ----------- 52

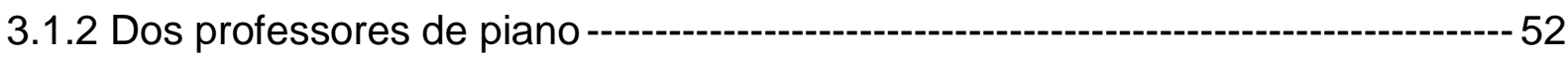

3.1.3 Atuação dos professores de piano ---.-- 59

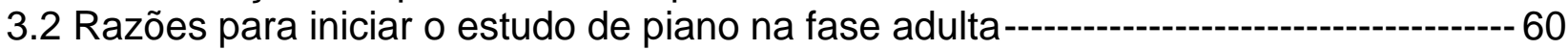

3.3 Descrição das práticas docentes para adultos iniciantes de piano ----------------- 64

3.3.1 Programa de ensino do piano para adultos ---

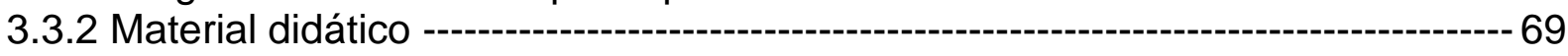

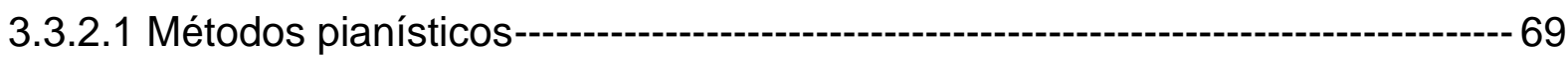

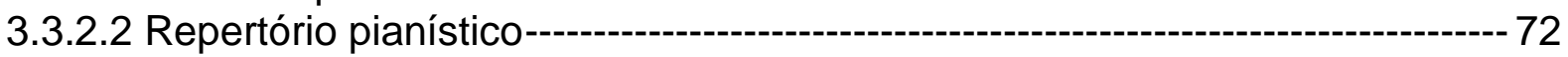

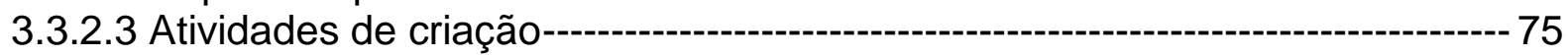

3.3.3 Modos de ensino -- 78

3.4 Experiências de adultos com a aprendizagem pianística---------------------------- 81

CONSIDERAÇÕES FINAIS - - 85

REFERÊNCIAS ---

APÊNDICES ---_- 95 


\section{INTRODUÇÃO}

Durante a minha atuação profissional, por mais de quinze anos, como professora particular de piano e em escolas de cursos livres e conservatórios de música, na cidade de Ribeirão Preto, sempre tive alunos em diferentes faixas etárias, entre eles, alunos adultos iniciantes no instrumento. Nesse percurso, uma aluna marcou-me bastante, a querida D. Luzia. Com 59 anos e recentemente aposentada pela seção de radiologia da Universidade de São Paulo, ao me procurar para ter aulas de piano, relatou-me que possuía um desejo antigo de aprender a tocar piano.

O perfil de D. Luzia juntamente com o de outros alunos adultos trouxeram-me inquietações que me instigaram à pesquisa e a reflexão acerca da iniciação pianística de adultos.

Vários autores têm estudado sobre a iniciação musical na infância, mas quando se trata do ensino e aprendizagem de música na fase adulta, principalmente no Brasil, a quantidade de trabalhos ainda é reduzida. Em virtude da diversidade de trabalhos já existentes destinados à classe infantil e poucos trabalhos brasileiros que abordem o ensino de música na fase adulta, o que confirma a importância deste estudo, esta pesquisa tem como finalidade promover uma reflexão acerca do tema, uma vez que o professor de piano que irá lecionar para o aluno adulto deve compreender as especificidades desse público alvo, de modo que as aulas possibilitem aquisições significativas através do fazer musical.

O cenário da prática de ensino e aprendizagem para alunos adultos iniciantes no piano em aulas particulares, escolas livres de música e conservatórios, na cidade de Ribeirão Preto, é o objeto de estudo dessa pesquisa. Além de professores que atuam no ensino de piano para alunos adultos, na atualidade, alunos adultos iniciantes de piano fazem parte desse estudo.

O objetivo geral, deste trabalho, é refletir sobre como se dá, na atualidade, o ensino de música através do piano para adultos iniciantes nesses diversos contextos e espaços musicais, especificamente na cidade de Ribeirão Preto. Os objetivos específicos são: fazer um levantamento de bibliografia estrangeira sobre o ensino de piano para o aluno adulto iniciante; listar materiais de ensino voltados para alunos adultos iniciantes no instrumento e responder às seguintes questões: Quais as especificidades do aluno adulto? Quais os modos de ensinar do professor de piano 
para o aluno adulto? Quais os materiais didáticos de iniciação utilizados pelos professores? Qual é a formação do docente?

Para a elaboração dessa pesquisa foi necessário, primeiramente, realizar um levantamento bibliográfico sobre a aprendizagem pianística, o ensino de piano e o ensino e aprendizagem de piano para adultos iniciantes. Recorremos então à obra do autor argentino-paraibano José Alberto Kaplan (2008), e de outros autores brasileiros como José Júlio Stateri (1996, 2014), Moema Craveiro Campos (2000), aos trabalhos de dissertação de José Francisco da Costa (2004), Aline Maria Tomanik (2011) e Artur Fabiano Albuquerque (2011), bem como os trabalhos de autores estadunidenses James Bastien (1973), Marienne Uszler et al. (2000), Denes Agay (2004), entre outros, onde é possível encontrar referências relacionadas ao estudo dessa pesquisa.

Acerca da aprendizagem pianística, José Alberto Kaplan (2008), em seu livro Teoria da Aprendizagem Pianística, apresenta que, além dos fatores de índole biológica, como a maturação do sistema nervoso, outros aspectos psicológicos são importantes para a aprendizagem do piano, tanto quanto as experiências prévias e o conhecimento das necessidades e objetivos dos alunos para com o estudo do instrumento. Dentre os aspectos psicológicos, o autor menciona a motivação, a memória e a transferência da aprendizagem.

Uma das questões a ser considerada sobre o ensino de piano possui ligação quanto aos tipos de programas de ensino adotados e utilizados por instituições e professores particulares desse instrumento. As obras de Kaplan (2008) e de José Júlio Stateri (2014), sendo este último o autor de Reflexões e práticas sobre uma filosofia da pedagogia musical, nos apresentam um posicionamento crítico sobre o assunto. Para esses autores, a efetivação de qualquer proposta de ensino requer, da parte do professor, um cuidadoso trabalho de análise, pesquisa e reflexão. Para isso, torna-se necessário conhecer os alunos quanto aos conhecimentos prévios, às aspirações e às necessidades que possuem. Assim, o ensino tem que partir da análise concreta de situações reais, considerando a intenção ou o desejo do aluno, pois "sem motivação não existiria, provavelmente, aprendizagem" (KAPLAN, 2008, p. 55). Nesse percurso, o professor deve "traçar metas realizáveis e renovar as estratégias de ensino" (STATERI, 2014, p. 21).

Outra questão a respeito do ensino de piano é o tipo de material didático utilizado nas aulas. Não necessariamente o professor usa métodos pianísticos 
impressos para ensinar. No entanto, ao escolher um determinado material didático, alguns aspectos devem ser considerados. A utilização de determinados materiais didáticos (métodos pianísticos, obras, dentre outros) não adequados para o aluno pode estar "intimamente ligada à metodologia de ensino e aos programas imperantes nas escolas e conservatórios de música" (KAPLAN, 2008, p. 59), além de poder ocasionar a falta de interesse do aluno pelo conteúdo proposto.

Stateri (1996), em sua obra Reflexões sobre o ensino do piano para adultos e adolescentes, apresenta vários aspectos próprios do aluno adulto de piano. Dentre eles, encontra-se a escolha do material a ser utilizado nas aulas de piano e a desmotivação por parte do aluno adulto quando o professor adota objetivos que não são aqueles que o aluno deseja.

Apesar da literatura pianística apresentar um amplo número de publicações, em se tratando de métodos brasileiros de iniciação ao piano para adultos, esse número ainda é reduzido. Os dados levantados por Marcello (2009) revelam que apenas dois métodos de iniciação pianística brasileiros voltados para o contexto de aula individual de piano exibem a palavra "adulto". Em contrapartida, a quantidade de métodos estadunidenses pianísticos voltados para o público adulto iniciante é expressiva. O livro The well-tempered keyboard teacher, de Marianne Uszler, Stewart Gordon e Scott McBride Smith (2000), trata do tema e apresenta uma lista significativa de métodos pianísticos de iniciação para adultos e coloca uma diferença entre os métodos de piano voltados aos alunos de cursos superiores de música, iniciantes no instrumento ou provenientes de outros cursos que não seja a música, e os métodos para outros grupos de alunos adultos.

Outro aspecto importante nesse contexto de aprendizagem do piano diz respeito às atividades de criação. Em sua obra "A educação musical e o novo Paradigma", Campos (2000) trata da criatividade e o estudo do piano. Para a autora, criar é transformar e a criatividade "presente em todo ser humano" é imprescindível para a criança e o adulto. "Se a criança o faz em função de seu crescimento, buscando sua própria realização, o adulto criativo, acrescenta informação e formação em suas atividades produtivas" (CAMPOS, 2000, p. 83-84). Considerando a importância da presença de atividades de criação no contexto de ensino e aprendizagem musical, a autora faz a seguinte pergunta: "que espaço reserva para a prática da criatividade?" (CAMPOS, 2000, p. 85). 
Sobre o ensino e aprendizagem do piano para adultos no Brasil, no contexto de aulas individuais, além da obra do professor Stateri (1996), a quantidade de trabalhos acadêmicos existente ainda é reduzida. A partir do levantamento bibliográfico que trata dessa temática, três trabalhos foram destacados. $O$ primeiro deles é a dissertação apresentada por José Francisco da Costa (2004), intitulada Aprendizagem pianística na idade adulta: sonho ou realidade? Esse trabalho apresenta questões relacionadas à aprendizagem pianística na fase adulta, inteligências múltiplas, desenvolvimento e desempenho motor, alterações fisiológicas em adultos, além da própria realidade desse público (sonho, desejo, motivação, interesse, entre outros que serão fatores preponderantes para a aprendizagem do piano nesse período da vida). O segundo trabalho chama-se Aprendizagem musical a partir da motivação: um estudo de caso com cinco alunos adultos de piano da cidade do Recife, uma dissertação de Artur Fabiano Araújo de Albuquerque (2011), que apresenta aspectos da aprendizagem musical através do piano do público adulto a partir da motivação. A terceira obra, também uma dissertação, cujo título é Um olhar sobre o ensino de piano para adultos, de Aline Maria Tomanik (2011), investiga questões relacionadas à prática do ensino de piano para adultos, por parte de professores que consolidaram sua formação pianística nos cursos de bacharelado de piano, nos quais não tiveram disciplinas pedagógicas direcionadas ao ensino desse instrumento. As habilidades pedagógicas desses professores entrevistados foram ocorrendo ao longo de suas carreiras, por meio da própria experiência em sala de aula e pela prática no instrumento. Para a autora, a formação do pianista no curso de bacharelado ainda precisa ser repensada, pois esse profissional trabalhará como professor e lidará com as diversas realidades do ensino de piano. O presente estudo incorporou do trabalho dessa autora algumas preocupações, buscando, também, outras especificidades, até mesmo complementares, acerca do tema.

Outra obra que apresenta aspectos do aluno adulto e métodos pianísticos para alunos iniciantes é o livro How to teach piano successfully, de James Bastien (1973). O autor descreve que, tradicionalmente, os alunos adultos representavam uma pequena parcela em aulas de piano. No entanto, cada vez mais esse perfil de aluno tem procurado por aulas de música, indicando que ensinar para adultos pode ser uma experiência gratificante. Eles buscam aprender a tocar esse instrumento 
pelo interesse que possuem, enquanto as crianças podem ter essas aulas apenas pelo desejo dos pais.

O livro The art of teaching piano, de organização de Denes Agay (2004), é uma obra estadunidense relevante sobre o ensino de piano para adultos iniciantes. Nele, Hadassah Sahr (2004) aponta, em seu capítulo The Adult Beginner, que o professor de piano que ensina para esse público-alvo deve ter em mente que o mesmo escolhe estudar o instrumento porque se encontra fortemente motivado. A autora acrescenta, ainda, que esses alunos possuem experiências musicais que influenciam suas atitudes quando tomam a decisão de estudar piano, mesmo essas experiências não possuindo ligações diretas à prática do instrumento. Cabe ao professor ficar atento a essas questões e incentivar atitudes favoráveis à aprendizagem do piano nessa fase da vida.

O presente trabalho se divide em três partes principais e as considerações finais. Na primeira parte, são apresentados os aspectos do adulto, da aprendizagem do adulto e da prática de ensino e aprendizagem pianística para esse público-alvo, a partir do corpo teórico que fundamenta esse estudo. Nessa parte, ainda é realizada uma breve análise de seis métodos de iniciação ao piano para adultos, sendo dois brasileiros e quatro estadunidenses.

$\mathrm{Na}$ segunda parte, é descrito os procedimentos metodológicos, como os processos de coleta de dados, a organização e a descrição, bem como a escolha pela análise de conteúdo, que foram relevantes para a condução desse estudo.

Na última parte, na análise e interpretação de dados, intitulada Solilóquios e Diálogos nos Processos de Ensino e Aprendizagem de Piano na Fase Adulta, as respostas das entrevistas dos professores e alunos adultos de piano foram reunidas e relacionadas em quatro categorias: trajetória musical, razões para iniciar o estudo de piano na fase adulta, descrição das práticas docentes para o adulto iniciante de piano e experiências de adultos na iniciação à aprendizagem pianística. Essas categorias foram construídas a partir dos objetivos da pesquisa. As várias relações dialógicas que ocorrem nos processos de ensino e aprendizagem são compreendidas, aqui, como "solilóquios e diálogos". A primeira é caracterizada por conversas dos entrevistados consigo mesmos. A segunda, dos entrevistados com suas experiências e interações nos diversos contextos e ambientes.

O trabalho se encerra com as considerações finais a respeito das práticas docentes no início do século XXI para um público adulto cada vez mais emergente. 


\section{APRECIAÇÃO CRÍTICA DA LITERATURA}

\subsection{0 adulto}

De acordo com Ferreira (1999), adulto significa "o indivíduo que atingiu o completo desenvolvimento e chegou à idade vigorosa", "que atingiu a maioridade, próprio de pessoa adulta", ou relativo ao período da vida após a adolescência. Quanto aos aspectos psicológicos, define-se que o adulto é o indivíduo que "atingiu plena maturidade, expressa em termos de adequada integração social e adequado controle das funções intelectuais e emocionais" (FERREIRA, 1999).

$\mathrm{O}$ termo adulto pode abarcar compreensões diversas. No entanto, alguns aspectos podem ser pensados na determinação de seu conceito, tais como aceitação de responsabilidade, predomínio da razão e equilíbrio emocional (LUDOJOSKI, 1972).

A idade adulta também pode ser caracterizada por fases, relacionadas às funções, obrigações ou atribuições que ocorrem nesse período da vida. Acerca disso, o psicólogo Justo (1997) apresenta algumas fases características da vida adulta, como: a "auto-realização e auto-imagem, a idade de responsabilidade máxima e a idade da liberdade". As duas primeiras fases indicam a escolha de rumo na vida, enquanto a fase da idade de responsabilidade máxima caracteriza o período em que o indivíduo assume a responsabilidade sobre si mesmo e sobre outras pessoas. $\mathrm{Na}$ fase da liberdade, o grau de responsabilidade se amplia conforme o grau da liberdade vai atingindo dimensões.

O processo de desenvolvimento do indivíduo é constante. Assim, segundo Medeiros (1998), o entendimento que se tem sobre o adulto é alguém que alcançou essa fase e traz suas experiências ao longo da vida. É aquele que se encontra em uma posição dinâmica e em desenvolvimento.

Quanto à faixa etária compreendida para o adulto, essa divergiu bastante nas pesquisas dos autores consultados. Embora fossem caracterizados como adultos, eles possuíam diferentes idades. Para Medeiros (1998), a faixa etária dos adultos participantes de seu trabalho permaneceu entre 18 e 36 anos. Para Costa (2004), essa faixa se iniciou em 34 anos e se estendeu até aos 58. Já na pesquisa de Albuquerque (2011), a fase adulta compreendeu o intervalo entre 23 a 55 anos. Tomanik (2011), por sua vez, observou o intervalo entre 30 e 70 anos para os adultos de sua pesquisa. 
Outros autores como Moura (1999) e Henrique et al. (2005) classificam a fase adulta por períodos relacionados à idade, tais como: idade adulta inicial ou idade adulta jovem (dos 22 aos 40 anos), idade adulta média (dos 40 aos 60 anos) e idade adulta tardia ou velhice (a partir de 60 anos).

Atualmente, o Estatuto da Juventude (Lei 12.852/2013) define como jovens as pessoas com idade entre 15 e 29 anos. Por outro lado, o Estatuto do Idoso (Lei $10.741 / 2003$ ) considera como idosos as pessoas com idade igual ou superior a 60 anos. Com base nesses documentos, e com essas faixas etárias bem definidas, foi considerado como adulto, para este trabalho, aquele que possui a faixa etária entre 30 e 59 anos de idade.

Outra questão acerca do adulto foi evidenciada pelo Relatório Global sobre a aprendizagem e Educação de Adultos, da Organização das Nações Unidas para a Educação, a Ciência e a Cultura - UNESCO (2010), ao apontar que cada vez mais adultos buscam desenvolver habilidades e conhecimentos diversos nos inúmeros contextos de educação, em espaços públicos ou privados. Dentre esses contextos, apontam-se os espaços de ensino e aprendizagem de música.

A respeito da educação de adultos e das práticas docentes para esse público, Schmidt1 (2013, p. 79-80), em seu artigo O futuro da educação de adulto², retrata:

\begin{abstract}
É uma tarefa interessante pensar sobre o futuro da educação de adultos. O futuro significa ser flexível [...]. Podemos olhar para o conceito de flexibilidade de várias maneiras diferentes. Ele simplesmente significa que podemos ser mais inovadores nas opções [de ensino] que oferecemos aos alunos. Flexibilidade também nos permite ser mais sensíveis às necessidades dos alunos. Como educadores de adultos, precisamos ser flexíveis em resposta ao desenvolvimento das necessidades dos alunos adultos e prontos para fornecer as oportunidades educacionais que precisam, quando necessárias.
\end{abstract}

A educação de adultos, na perspectiva de aprendizagem ao longo da vida, apresenta desafios para os profissionais e para os vários contextos e espaços onde processos de ensino e aprendizagem de adultos ocorrem, no sentido de refletir as particularidades desse público e promover práticas e ações significativas no processo de aquisição de conhecimentos.

\footnotetext{
${ }^{1}$ Steven W. Schmidt é professor doutor, livre docente e coordenador do Programa de Educação de Adulto no Ensino Superior da Universidade Carolina do Leste, no Estado da Carolina do Norte (EUA) e presidente da Associação Americana de Adultos e Educação Continuada (AAACE).

2 Título original: The Future of Adult Education.
} 


\subsection{0 aluno adulto de piano}

Adultos buscam estudar piano por razões diversas e possuem experiências várias com a música. Algumas dessas experiências são advindas de diversos meios disponíveis de informação e comunicação (rádio, TV, internet, celulares, computadores, CDs, DVDs, entre outros), de idas a concertos e em apresentações musicais, de leituras sobre música e até através de participação em corais. Mesmas essas não sendo, necessariamente, ligadas à prática do piano de forma direta, influenciam suas atitudes na escolha por esse tipo de aprendizado.

Quanto aos perfis dos adultos que procuram por aulas de piano, diversos foram identificados nos trabalhos de Bastien (1973), Stateri (1996), Uszler (2000), Costa (2004) e Sahr (2004). Dentre esses perfis estão (1) aqueles que desejam retornar às aulas depois de interromper os estudos por muitos anos, (2) aqueles que atuam em uma área diferente da música e desejam tocar um instrumento musical, (3) aqueles que possuem um desejo antigo de estudar piano e somente agora podem realizar esse desejo, (4) aqueles que querem fazer uma atividade em tempo livre, (5) os que possuem paixão pela arte, (6) os que, agora, têm tempo para realizar uma atividade de seu interesse musical e desejam aprender a tocar piano, dentre outros perfis.

O trabalho de Albuquerque (2011) indica que o objetivo principal dos alunos adultos entrevistados na cidade de Recife não se fundamenta na busca pelo desenvolvimento virtuosístico, em razão do percurso vivido por eles, de suas disponibilidades de tempo e de outros objetivos pessoais. Essa realidade também é verificada no trabalho de Tomanik (2011), que buscou investigar a prática de ensino e aprendizagem de piano para adultos iniciantes, na cidade de Belo Horizonte. De acordo com a autora, as respostas dos alunos adultos revelam que os mesmos são profissionais em outras áreas, sendo aposentados ou não, e não buscam a profissionalização no instrumento, mas sim um hobby.

Segundo as projeções e estimativas da população brasileira, realizadas pelo Instituto Brasileiro de Geografia e Estatística ${ }^{3}$ (IBGE), em 2000, a faixa etária de pessoas entre 15 a 64 anos correspondia a $64,35 \%$ da população brasileira. Em

${ }^{3}$ Disponível em: <http://www.ibge.gov.br/apps/populacao/projecao/>. Acesso em: 01 jun. 2016. 
2016, a mesma faixa etária representa 69,14\%. Para o ano de 2022, a estimativa é de $69,76 \%$. O que se verifica é a correlação direta entre a percentagem que abarca a população brasileira adulta e o interesse desse público pelo estudo relacionado à música, culminando com a crescente procura de adultos por aulas de instrumentos musicais.

A participação ativa da população adulta no estudo do piano, ou teclado eletrônico, ainda pode ser verificada em trabalhos de pesquisadores de outros países, entre eles, dos EUA (ORLOFKSY; SMITH, 1997; COOPER, 2001; JUTRAS, 2006; WRISTEN, 2006), da Coreia do Sul (ROULSTON; JUTRAS; KIM, 2015), do Reino Unido (TAYLOR, 2011; CREECH et al., 2013; PERKINS; AUFEGGER; WILLIANOM, 2014) e da Austrália (COUTTS, 2015). Esses trabalhos retratam as motivações e os benefícios do estudo desses instrumentos na fase adulta e as estratégias de ensino e aprendizagem para o aluno adulto nesse contexto específico.

\subsection{0 aluno adulto e a aprendizagem pianística}

Aprender a tocar piano é uma experiência que integra a aprendizagem de determinados saberes à prática no instrumento. Sobre a aprendizagem instrumental, Kaplan (2008, p. 12) explica que esse processo, sendo de caráter perceptivo-motor e com abundante presença de aspectos cognitivos, "é basicamente um processo psicológico", influenciado por fatores biológicos (a maturação do sistema nervoso) e cognitivos (a motivação, a memória e a transferência da aprendizagem).

O autor descreve que o indivíduo age de acordo com o processo de seleção e organização de estímulos externos e internos que chegam a ele, podendo ser auditivos, visuais, cinestésicos ou de qualquer outro tipo, recebidos através dos órgãos dos sentidos. Os processos de seleção e organização de estímulos estão ligados de modo direto ao objetivo que se pretende atingir e à experiência prévia do indivíduo. Ou seja, as experiências prévias relacionadas à idade cronológica, aos aspectos musculares e motores, aos movimentos e sua coordenação, e aos objetivos a serem atingidos (por exemplo, uma partitura a ser executada) são imprescindíveis na aquisição de habilidades motoras, sendo diferente para cada indivíduo, visto que haverá tantas compreensões de uma mesma quantidade de informações. Assim, a habilidade motora é entendida por Kaplan (2008, p. 41) como: 
A capacidade adquirida, por aprendizagem de coordenar uma série de movimentos com a finalidade de atingir objetivos prefixados com um máximo de eficiência e um mínimo de esforço, entendendo-se por esforço o gasto de energia e em tempo necessários para aprender e realizar a tarefa proposta.

Além da coordenação de vários movimentos, outro aspecto da aprendizagem do piano é a notação musical relacionada à leitura e à interpretação de uma partitura.

O processo de leitura da partitura, integrado à coordenação dos movimentos das mãos no piano, pode se tornar muito difícil para alunos que estão iniciando o aprendizado. Durante as aulas, é frequente a existência de relatos de alunos adultos iniciantes, afirmando que é necessário "pensar em muitas coisas", ou ainda, "recorrer à memória" para ler a partitura e, simultaneamente, tocar no piano. A respeito da memória como um elemento essencial na aprendizagem instrumental, Kaplan (2008, p. 63-64) descreve que diferentes tipos de memórias podem contribuir na execução e memorização de uma peça musical. Dentre eles, estão (1) a memória visual, que ajuda a fixar a imagem da partitura, (2) a memória cinestésica, que automatiza os movimentos através da repetição dos mesmos, (3) a memória auditiva, que registra na memória as sucessões sonoras, e (4) a memória racional, que ajuda a compreender a composição.

Soma-se a esses aspectos da aprendizagem instrumental, a transferência de aprendizagem, entendida como "a possibilidade de aplicar em uma nova situação conhecimentos, hábitos, métodos, etc., adquiridos em outras circunstâncias" (KAPLAN, 2008, p. 78). Desse modo, através de suas experiências e desenvolvimento gradativo no piano, os alunos poderão ler e tocar novas peças, reconhecendo e aplicando aspectos já aprendidos e conhecendo outros novos.

Diante da aprendizagem do instrumento, verifica-se a importância da motivação como um componente propulsor para iniciar e seguir com os estudos. Ao considerar a relevância dos fatores de ordem psicológica na aprendizagem, como a motivação, Kaplan (2008, p. 56), que foi pianista e atuou na docência do piano por mais de 30 anos, ressalta, ainda, que qualquer tipo de aprendizagem, seja ela motora, de compreensão de conceitos, dentre outras, somente se realiza através das atividades do aluno, "que precisa de motivos para levá-los a cabo". Quanto ao aluno adulto, a motivação, geralmente, o acompanha, pois é um perfil de aluno que 
já vem motivado para a aula. "Ele sente vontade ou necessidade, tanto que, por iniciativa própria, procura o professor" (STATERI, 1996, p. 9).

É diante dos componentes motores, cognitivos e afetivos, tão necessários à aprendizagem, que o aluno irá se deparar no estudo do piano. Tratando-se de adultos, estes se relacionam com a aprendizagem, obviamente, de modo diferente em comparação à criança. Ao conhecer os aspectos da aprendizagem desse perfil de aluno, o professor poderá nortear seus modos de ensino para esse público, de modo a torná-los mais significativos.

Alguns aspectos entre crianças e adultos, diante da aprendizagem, podem ser verificados no trabalho de Hamann e Cooper (2016), conforme é apresentado no quadro 1.

\begin{tabular}{|c|c|}
\hline Em adultos: & Em crianças: \\
\hline Mais resistentes & Menos resistentes \\
\hline Aluno define o ritmo & Professor define o ritmo \\
\hline Maior grau de atenção & Menor grau de atenção \\
\hline Traços pessoais e individuais dominantes & Aspectos de maturação a serem desenvolvidos \\
\hline Alto interesse nos aspectos teóricos & $\begin{array}{c}\text { Constrói a aprendizagem através do concreto ao } \\
\text { invés do teórico }\end{array}$ \\
\hline Menos capacidade de memorização & Alta capacidade de memorização \\
\hline Alta capacidade lógica, de racionalização e de \\
objetividade
\end{tabular}

Quadro 1 - Aspectos comparativos entre adultos e crianças no processo de aprendizagem Fonte: Hamann e Cooper (2016)

Os aspectos apresentados no quadro 1 são reiterados, e outros são descritos, por Uszler (2000). Para a autora, se por um lado, muitos dos aspectos dos adultos revelam-se vantajosos para aprender uma habilidade, outros podem trazer impedimentos, mesmo que por períodos curtos. Acerca das vantagens, tem-se que o adulto possui um tempo de concentração relativamente longo, especialmente se as atividades forem interessantes e variadas. O mesmo também é capaz de realizar estudos independentes, de ler e responder com prontidão à comunicação verbal, além de possuir desejo de contextualizar os assuntos e chegar a uma síntese. 0 adulto é ansioso para entender as relações, colocando perguntas, a fim de esclarecer seus questionamentos e desfrutar de "referências alternativas" (USZLER, 2000, p. 58-59).

Quanto às desvantagens, tem-se que o adulto busca, antecipadamente, entender, na prática, aquilo que foi apresentado a ele. Ele pode, também, insistir em cada atividade, por não confiar muito nos sentidos ou na memória. Também pode 
permitir que interesses paralelos desviem a atenção do assunto em questão, além de ser propenso a verbalizar antes de agir. A autora acrescenta, ainda, que o adulto explica e racionaliza com antecedência o que vai acontecer, podendo resistir às novas ideias ou ser menos interessados em experiências novas ou não conhecidas.

Para Sahr (2004, p. 257), os adultos podem se sentir frustrados, uma vez que são capazes de compreender os conceitos musicais muito mais rápido do que desenvolver as habilidades necessárias para a execução instrumental. E a ideia de cometer um erro pode ser perturbador para eles. Essas questões podem levá-los à inquietação e a considerarem que não são hábeis e não tocarão muito bem o instrumento. Questionamentos como "você acha que é possível eu aprender a tocar" ou "é tolice de minha parte querer ter aulas de piano", também demonstram preocupação por parte dos alunos adultos iniciantes.

Acerca das atitudes do aluno adulto diante da aprendizagem do piano, 0 professor Stateri (1996, p. 9-10) relata que o adulto tem medo de se deparar com situações constrangedoras. Por isso, é mais difícil convencê-lo a se apresentar em público, além de ter pressa em aprender, como que para "recuperar o tempo perdido". O autor aponta, ainda, que o adulto tem mania de perfeição, resultando quase sempre em autocrítica exagerada, e pode duvidar quando o professor diz que a lição já está bem preparada, sendo necessário "convencê-lo de que errar faz parte do processo de aprendizagem".

Sobre o professor que ensina para esse público-alvo, Stateri (1996) indica alguns fatores que podem desmotivá-los, como dificuldades exageradas, sequência não apropriada de problemas a serem resolvidos, materiais didáticos que desagradam o aluno (que devem ser trocados quando não contemplam os objetivos e necessidades do discente), postura do professor (forma de corrigir e de se referir aos problemas dos alunos) e objetivos que o professor determina e não são os que os alunos desejam. Desse modo, considera-se importante que o docente mantenha o equilíbrio afetivo, pois o aluno adulto também precisa de simpatia e da compreensão do mesmo. Esse tem sido um apontamento para o papel do professor, bem como o seu interesse pela busca de soluções de problemas e de questões múltiplas que possam emergir durante o processo de ensino e aprendizagem pianística.

A respeito da estrutura física dos adultos, Uszler (2000) considera que eles "se encaixam" no instrumento, já que podem alcançar o pedal e as extremidades do 
teclado, possuem altura suficiente para terem uma visão ampla do teclado, podem alcançar uma oitava com relativa facilidade, têm controle sobre os movimentos finos e utilizam a relação corpo e instrumento com harmonia, a fim de saberem buscar os recursos disponíveis em cada um.

Sobre o aspecto motor do adulto, a autora aponta que esse aluno já desenvolveu um vasto repertório de habilidades motoras, muitos dos quais podem ser aplicadas na aprendizagem de um instrumento. Destacam ainda que, além das vantagens em relação aos alunos que se encontram na fase infantil, no que diz respeito ao tamanho, força e altura, o adulto tem conhecimento da importância do tempo e da precisão no uso dos movimentos. A coordenação olho-mão já ocorreu em várias atividades, como a escrita e a manipulação de objetos.

Por outro lado, Uszler (2000) salienta que o adulto pode considerar difícil mudar padrões de gestos ou movimentos adquiridos e aprendidos de determinadas maneiras e em outras condições, pois o movimento que é flexível em determinadas situações, pode facilmente tornar-se tenso e rígido em outras circunstâncias. Essa rigidez física pode refletir mais uma tensão psicológica do que a incapacidade do corpo para realizar movimentos específicos. Além disso, a mesma autora argumenta que adultos podem não ser tolerantes com as dificuldades e com o tempo necessário para a aquisição de novas habilidades motoras relacionadas à execução instrumental, sendo necessário alcançar sucessos que sejam reconhecidos por eles mesmos para que possam prosseguir com os estudos.

Outros aspectos considerados por Uszler (2000) como não favoráveis são as tensões desnecessárias por parte de adultos iniciantes no instrumento, ao buscar atingir de imediato a perfeição dos movimentos através de práticas intensivas, a espera que a sua compreensão de "como fazer" se traduza rapidamente em ação eficiente, a não possível disposição de aceitar o fato de que a aprendizagem de novos movimentos e gestos leva tempo e prática, o cansaço físico ou a distração durante o estudo e a não aceitação de instruções, uma vez que o adulto já adquiriu movimentos precisos realizados em outros momentos.

As diversas influências internas e externas recebidas durante todo o período de vida atuam diretamente sobre o desenvolvimento físico, motor, cognitivo e emocional da pessoa. Bee e Mitchell (1984) explicam que a constituição genética 
específica e a maturação ${ }^{4}$, comum aos indivíduos (influências internas), e as experiências pelas quais os mesmos passam, desde a concepção até a morte nos diversos tipos de variações ambientais (influências externas), constituem o desenvolvimento do ser humano. De acordo com essas autoras, a interação entre as influências internas e externas estão presentes em todos os aspectos do desenvolvimento do comportamento. Em suas palavras, "não há casos que possamos imaginar em que um comportamento seja totalmente interna ou externamente determinado" (BEE; MITCHELL, 1984, p. 16). Assim, a execução de determinadas tarefas executadas pelo indivíduo está ligada aos efeitos de fatores internos, como a hereditariedade, e à maturação do indivíduo, interagidos aos estímulos de seu ambiente.

Tais aspectos também são expostos no trabalho de Costa (2004), que buscou investigar, principalmente, as questões motoras relacionadas à aprendizagem pianística na fase adulta. $\mathrm{O}$ autor retrata que o desempenho motor em adultos resulta da interação de uma série de variáveis, tais como o tipo de tarefa ${ }^{5}$, os fatores ambientais (por exemplo, um espaço propício para que essa atividade seja realizada), e os aspectos cognitivos, afetivos (motivação, autoconfiança, relação com o professor) e motores (relacionados ao tempo de vida do adulto e às possíveis alterações na realização de determinadas tarefas).

No entanto, o estudo de Costa (2004) também aponta que o desempenho motor de um indivíduo pode estar relacionado às alterações provenientes do envelhecimento para algumas tarefas, mas não para todas. Costa (2004, p. 25) explica que é necessário verificar se a tarefa requer "velocidade, precisão, flexibilidade de articulações, resistência cardiovascular ou memorização", pois é bem provável que determinadas tarefas não recarreguem excessivamente "os sistemas fisiológicos debilitados pelo envelhecimento, ou ainda, que as condições feitas a um sistema em declínio possam ser acomodadas por outros sistemas saudáveis". Contudo, se algumas funções do corpo sofrem alterações conforme o avançar da idade, em sentido decrescente, outras se intensificam em sentido crescente, como o

\footnotetext{
4 O termo maturação refere-se ao desenvolvimento de padrões de mudança e crescimento, bem como às habilidades adquiridas durante todo o tempo de vida (Idem).

5 As tarefas motoras da pessoa "se estendem de atividades diárias a habilidades especializadas, sendo que, em algumas delas, é preciso alto nível de precisão, enquanto em outras, alto grau de velocidade ou, mesmo, uma combinação de ambos" (COSTA, 2004, p. 24).
} 
senso de julgamento e de avaliação, os conhecimentos e as experiências (MEDEIROS, 1998).

Assim, as experiências do adulto com a aprendizagem pianística são delineadas pelos seus aspectos físicos, motores, cognitivos e emocionais, e com a participação de seu entorno, como os ambientes e contextos vividos, entre outros elementos que poderão ser favoráveis, ou não, a esse processo.

\subsection{A aprendizagem de piano e criatividade}

Não seria a criatividade a força geradora de respostas a estímulos absorvidos pela sensibilidade do homem, componente que o acompanha desde a infância por todo o seu desenvolvimento, dando-lhe o sentido de estar vivo? (CAMPOS, 2000, p. 84).

Apesar do termo "criatividade" ser definido de muitas maneiras, ele também pode ser caracterizado como "ideia ou invenção original, reelaboração e aperfeiçoamento de ideias já existentes" (ALENCAR, 1993, p. 15).

A respeito da criatividade e o estudo do piano, Campos (2000, p. 4) ressalta que, em virtude do ensino tradicional de piano ter como objetivo maior o de "ler música, tocar sem errar", as atividades de criação e livre expressão estão quase sempre em planos secundários ou à margem das aulas. Ressalta, ainda, que há certo sentimento de insatisfação nos estudantes de piano quando, após um longo período de estudo no instrumento, não se sentem muito preparados para tocar uma melodia "tirada de ouvido", acompanhar uma determinada canção ou, ainda, improvisar no piano.

A ausência de atividades nas aulas de piano, como "tocar de ouvido", compor ou improvisar, pode estar relacionada ao fato de que os professores podem não estarem dispostos a mudar os seus modos de ensino, estando familiarizados com um tipo de instrução que não contemple essas práticas no piano. Por outro lado, professores que incorporam tais práticas em suas aulas podem encontrar barreiras por parte de alguns alunos, como os adultos iniciantes no instrumento, uma vez que os adultos podem se sentir em situação não confortável por considerar que não possuem conhecimentos suficientes para realizar atividades que envolvam criação e composição no piano. Esses alunos podem entender que tal prática, geralmente, é restrita aos especialistas, como os compositores que se despontam com suas obras. 
Uszler (2000) retrata que, em geral, quanto mais jovem o aluno, maior a vontade de experimentar algo desconhecido. Partindo do exemplo da proposta de atividade de improvisação, a autora aponta que os mais jovens podem encarar muito bem quando Ihe pedirem para improvisar em um ambiente em que outras pessoas estão presentes. Eles podem estar dispostos a experimentar algo novo através da prática de improvisação ao invés de "verbalizar" a respeito da atividade. Contudo, o adulto que tem aprendido a lidar com a vida, baseada, primeiramente, no conhecimento, pode considerar que o aprendizado, ou a experiência por tentativa e erro, seja perda de tempo e embaraçoso. Já o idoso prefere a segurança das instruções por escrito, uma vez que tem aprendido que a memória nem sempre é confiável.

Defensora de uma proposta de utilização do piano mais criativa através da experimentação, Campos (2000, p. 3) ressalta que as atividades de improvisação, de leitura, de composição, de interpretação, bem como a relação do aluno com o instrumento, devem ser apoiadas no "prazer de fazer, de pesquisar, de conhecer, de conviver". A partir disso, então, evita-se "a eterna preparação desse aluno para só algum dia realizar alguma coisa".

Para a autora, é preciso explorar o piano, pois o conhecimento de sua estrutura e mecanismo (caixa acústica, cordas - comprimento, espessura e quantidade diferentes para cada região, martelos, pedais) trará ao aluno melhor compreensão dos recursos que o instrumento oferece, servirão de elementos que poderão ser incorporados na improvisação e poderão ser reconhecidos em uma obra musical. Além disso, considera necessário o "descondicionamento do ouvido" no próprio instrumento, pois o ouvido condicionado ao sistema temperado pode levar os alunos iniciantes a ter a impressão de sons estranhos ou erros, e a sensação de que não estão fazendo música. Instigar os alunos a experimentarem inúmeras combinações sonoras no instrumento é um caminho, pois através das possíveis relações entre o som e tempo, ideias vão ocorrendo e tomando forma.

Desenvolver atividades criativas no estudo do piano, em qualquer faixa etária e em nível de desenvolvimento no instrumento, implica em conferir a esse processo a presença de ações espontâneas, reforçando as experiências de aprendizagem aí envolvidas, que não se resumem na leitura de partitura, tão importante, mas não somente. 


\subsection{Métodos de iniciação pianística para adultos}

A palavra método, do grego méthodos, significa "um caminho pelo qual se atinge um objetivo", ou ainda, "modo de proceder, maneira de agir, meio, [...], processo ou técnica de ensino" (FERREIRA, 1999).

Compreendendo o método pianístico como um material que propõe um caminho para atingir determinado objetivo, a função de um livro-método, segundo Jacobson (2006), é fornecer uma progressão lógica para a aprendizagem dos conceitos e habilidades musicais necessárias à prática do piano. Nem sempre o professor faz uso de métodos impressos para ensinar. No entanto, a escolha de um determinado material "pode ajudar os alunos a percorrerem os estágios iniciais com relativa facilidade e, ao mesmo tempo, estabelecer uma base sólida para futuros estudos" (JACOBSON, 2006, p. 41).

Os métodos de iniciação ao piano para adulto possuem diferenças daqueles direcionados para crianças, mesmo que as orientações iniciais possam ser semelhantes. Esses métodos apresentam textos com explicações acerca do conceito a ser aprendido e as figuras não servem de adornos, como nos métodos infantis, mas demonstram conteúdos relacionados à prática do piano (SANTOS; CORVISIER, 2012).

Para Stateri (1996, p. 5) os métodos infantis não são viáveis para o adulto, não somente pela predominância dos textos e figuras, voltados ao universo infantil, mas pela dosagem de dificuldades que é inadequada. Além do mais, "os problemas anatômico-fisiológicos, que poderão aparecer com o estudo da técnica, serão, naturalmente, da mesma forma, diferentes". Ao discorrer sobre alternativas didáticas para o ensino do aluno adulto iniciante, Stateri (1996) recomenda a leitura de quatro obras, sendo duas de autores estadunidenses, como Basic Piano for Adults (ROBINSON, 1964) e Music for Piano for the Older Beginner (PACE, 1967), e duas de sua autoria: Curso do Pianista Moderno (STATERI, 1978) e Piano Moderno (STATERI, 1988). Apesar de não usar a palavra "adulto", Stateri (1996) considera que essa última obra tem um programa mais rápido e próprio para o aluno adulto, com leitura direta nas claves de Sol e Fá, melodias folclóricas e não conhecidas, dificuldades rítmicas e técnicas apresentadas de modo gradativo e harmonia clássico-romântica. 
Marcello (2009), em seu trabalho Iniciação de adultos ao piano: métodos brasileiros comercializados na cidade de São Paulo (SP), apontou a existência de apenas dois métodos brasileiros (desconhecidos pelos professores entrevistados) de iniciação ao piano que exibem em seu título a palavra "adulto": Tocar Piano 1 Iniciação para adultos (CURY; THIELE, 1997) e Toque Piano Hoje: Curso de Piano para adulto - Volume 1 (BUCHER, 2009). Esse último já apresenta os volumes II (2010) e III (2011), editados pela própria autora.

Em contrapartida, a quantidade de métodos de piano estadunidenses específicos para a fase adulta é muito superior em comparação à brasileira, sendo muitos deles mencionados por Bastien (1973, p. 70), Uszler (2000, p. 67-77) e Agay (2004, p. 263), autores estadunidenses.

Jacobson (2006, p. 61-62), ao estudar o tema, aponta que os seguintes aspectos devem ser considerados:

- O intelecto do aluno: Textos e conteúdos teóricos podem ser mais explorados, pois o adulto pode entender conceitos abstratos muito mais fácil do que a criança;

- Apresentação e formato do material: Adultos em geral (exceto alguns adultos mais velhos) têm condições de ler fontes de letras em tamanho médio. Os títulos das peças não devem ser infantilizados;

- Técnica: Alguns adultos terão a coordenação mais desenvolvida devido às habilidades desenvolvidas e à prática de atividades, tais como digitação e outras atividades físicas. Um método que exige mais técnica pode ser utilizado para esses adultos. Outros podem ter dificuldades de coordenar os movimentos necessários à execução do instrumento. Assim, o professor deve, primeiramente, analisar os movimentos de coordenação do aluno e, somente após, escolher o método que possa trabalhar esses aspectos;

- Repertório: Sempre que possível, apresentar um repertório familiar;

- Desenvolvimento de habilidades de escuta musical: Oferecer harmonização de melodias familiares e oportunidades ao aluno para que ele possa tocar "de ouvido";

- Expectativa do aluno: Alunos adultos têm expectativas e metas préestabelecidas. Muitas vezes, as expectativas dos adultos são maiores do 
que as das crianças. Apesar de variar muito de aluno para aluno, o método escolhido deve apoiar tais expectativas;

- Experiência estética: Os métodos que permitem uma experiência estética num curto período de tempo são essenciais;

- Satisfação: Os adultos, geralmente, estão dispostos a trabalhar duro por algum tempo, mas querem sentir prazer enquanto estão fazendo música. Métodos pianísticos interessantes podem oferecer experiências positivas de aprendizagem.

A escolha de materiais didáticos apropriados para o aluno é um aspecto importante na prática docente. Cada material pode conter pontos favoráveis ou desfavoráveis. No entanto, ao conhecer as abordagens de diferentes materiais didáticos, o professor poderá utilizar aquele que mais atende, de modo favorável, o perfil de seu aluno adulto. Ainda, assim, recortes dos conteúdos poderão ser realizados, atividades outras poderão ser inseridas e relacionadas, considerando as propostas de ensino que abarcam os objetivos e necessidades do aluno.

Com o intuito de conhecer os tipos de abordagens dos materiais de iniciação ao piano para alunos adultos, dois métodos pianísticos brasileiros e quatro estadunidenses foram selecionados para uma breve análise quanto à apresentação dos conteúdos, tipos de repertório e presença de atividades criativas. Os métodos pianísticos estão descritos em ordem cronológica.

\subsubsection{Adult Piano Course - Book One, Preparatory (THOMPSON, 1943)}

\section{Conteúdo}

Após o índice, o autor explica a proposta do livro. Nessa apresentação, o autor relata a importância de três aspectos presentes na música: melodia, harmonia e ritmo. Ele considera que tais aspectos devem ser utilizados com eficiência para introduzir o aluno no estudo da música, além de ressaltar a importância da prática musical em conjunto, do dedilhado, da leitura e exercícios que auxiliam essa prática, como bater palmas e solfejar as notas. $O$ autor termina o prefácio esclarecendo que o método é um livro preparatório e designado especialmente para adultos e tem por objetivo levar o aluno rapidamente, mas cuidadosamente, através de elementos necessários ao estudo do piano. Ao concluir o livro, o aluno estará preparado para iniciar o método Second Grade Book, também de sua autoria, sugere o autor. 
Em seguida, inicia-se a "Seção Introdutória". Nessa seção, o autor inicialmente mostra no teclado as posições das notas musicais Dó, Ré, Mi, Fá, Sol, Lá e $\mathrm{Si}$, as claves de Sol e Fá, as figuras musicais e suas pausas (semibreve, mínima, semínima e colcheia), a barra divisória, os compassos simples (binário, ternário e quaternário), a leitura das notas musicais a partir do Dó Central nas claves de Sol e Fá (aumentando a extensão gradativamente em ambas as mãos), os sinais de alterações (sustenido, bemol e bequadro), a ligadura, o ponto de aumento, a barra de repetição e indicações de dinâmica (crescendo, decrescendo, $f, m p$ ). A leitura das notas inicia-se na região central do piano e em ambas as claves de Sol (com as notas Dó, Ré, Mi) e Fá (Dó, Si, Lá) e, gradativamente, expandindo esse âmbito. Tais conteúdos são apresentados através de dezesseis peças preparatórias, de autoria do próprio autor, e de arranjos de melodias folclóricas estadunidenses, ou não, sempre em dueto com o professor.

Após, inicia-se a segunda parte do método, intitulada "Seção Principal". No início dessa seção, há outro texto explicativo do autor, orientando o aluno como estudar, a importância da precisão, da revisão dos estudos e peças, dedilhados e leitura. Em seguida, inicia-se os estudos (adaptações do método Hanon) e as peças (piano solo) que trabalham aspectos de articulação (staccato, legato, non legato), intensidade ( $f, m f, p, p p, m p$ ), e andamento (Largo, Andante, Andantino, Moderato, Allegretto, Allegro), tom e semitom, semicolcheia, quiáltera, fermata, linha de oitava, trinado, as escalas em várias tonalidades (Dó Maior, Sol Maior, Fá Maior, Ré Maior, Lá Maior, Mi Maior, Fá Maior, Sib Maior, Mib Maior, Láb Maior), as tríades maiores e suas inversões, arpejos e compasso binário composto. O livro termina com um glossário.

\section{Repertório}

O repertório contém peças de autoria do autor, arranjos de melodias folclóricas e tradicionais estadunidenses e de alguns países e obras de vários compositores, dentre eles Johannes Brahms, Piotr llitch Tchaikovsky e Wolfgang Amadeus Mozart.

\section{Atividades Criativas}

O objetivo principal do método é desenvolver aspectos relacionados à leitura da partitura, com iniciação nas teclas brancas e na posição de Dó Central. 
Gradativamente, o âmbito é expandido e outras tonalidades são inseridas através de peças ou estudos.

O livro não apresenta figuras com temáticas infantis, mas ilustrações que orientam o aluno quanto ao conceito a ser apreendido, levando em conta o nível de compreensão do adulto. Em língua inglesa, o método não apresenta atividades criativas. No entanto, vale ressaltar a edição desse material estadunidense, de 1943, voltado para o público adulto iniciante no instrumento. O professor poderá complementar a proposta do método inserindo outras atividades que vão além da leitura da partitura, como a prática de tocar "de ouvido", a criação e a improvisação, diferentes interpretações das peças, dentre outras.

\subsubsection{The older beginner piano course - Level 1 (BASTIEN, 1977)}

\section{Conteúdo}

O livro é dividido em 10 unidades. Na primeira unidade, após apresentar o teclado, os grupos de 2 e 3 teclas pretas e as regiões grave, médio e agudo, vários exercícios são indicados para tocar nos grupos de teclas pretas, utilizando as mãos direita e esquerda e as diferentes regiões do teclado. Em seguida, é apresentada a posição das notas no teclado (Dó a $\mathrm{Si}$ ), os números dos dedos da mão esquerda e direita, a apresentação das figuras musicais semínima, mínima e, posteriormente, a semibreve. Sem apresentar as claves e, agora, partindo das teclas brancas (em posição de pentacorde de Dó Maior, em ambas as mãos), o autor utiliza as figuras musicais e o dedilhado para indicar a duração de cada nota e a posição de ambas as mãos para a execução das peças.

$\mathrm{Na}$ segunda unidade, o autor apresenta a posição das notas nas claves de Sol e Fá (em posição de pentacorde de Dó Maior), os compassos simples binário, ternário e quaternário (tendo a semínima como unidade de tempo. Posteriormente, a mínima também aparecerá como unidade de tempo), os acordes de Dó Maior e Sol Maior com sétima na primeira inversão, a ligadura, as pausas da semibreve, mínima e semínima e o ponto de aumento. Em seguida, são apresentados os conteúdos nas unidades: dinâmicas ( $p, m p, m f, f)$, ligadura de frases, colcheia, semínima pontuada, staccato, fermata, sinais e barras de repetições, crescendo e decrescendo, ritardo, sinais de alterações (bemol, bequadro e sustenido), tom e semitom, pentacordes de Sol Maior, Fá Maior, Ré Maior, Lá Maior e Mi Maior (seus respectivos acordes I, IV e 
V) e exercícios de transposição. Nas unidades seguintes, ainda são apresentadas as escalas de Dó Maior, Sol Maior e Fá Maior, a armadura de clave de sustenidos, o compasso composto binário (6/8), a utilização do pedal direito e a formação do acorde maior e menor.

No final de cada unidade, são propostos exercícios de revisão teórica dos conteúdos trabalhados. Após a última unidade do livro, o autor apresenta um repertório de 6 peças e um capítulo de referências, onde são apresentados alguns acordes, as escalas nas tonalidades de Ré Maior, Lá Maior e Mi Maior e um Dicionário Musical.

\section{Repertório}

O repertório abarca arranjos de melodias tradicionais e folclóricas estadunidenses, de autoria do autor e do repertório erudito europeu.

\section{Atividades Criativas}

O material apresenta uma abordagem de teoria aplicada. Os conteúdos teóricos são apresentados somente quando necessários à prática dos exercícios ou das peças. O método possui uma abordagem de múltiplas tonalidades, baseada na leitura por desenho melódico (desde a pré-leitura, o autor chama a atenção para o movimento de descida, subida ou repetição da nota), posições de pentacordes, progressão de acordes e melodia acompanhada por acordes e cifras. Contém atividades de transposição a partir da unidade 5, o que demonstra a preocupação do autor em desenvolver o "ouvido". No entanto, a quantidade dessas atividades presentes no método ainda é muito reduzida. Esse material está disponível em castellano, o que o torna um material em língua acessível para o professor e aluno.

\subsubsection{Tocar piano1: Iniciação para adultos (CURY; THIELE, 1997)}

\section{Conteúdo}

Segundo Cury e Thiele (1997), o material é fruto de uma longa experiência com o ensino de piano para as mais diferentes faixas etárias. A falta de diversidade de materiais específicos para adultos e adolescentes foi uma carência observada pelas autoras. "Daí a necessidade de criar um material de iniciação para adultos que 
fosse compatível com suas possibilidades físicas e intelectuais" (CURY; THIELE, 1997, p. 5).

Para elas, a música tem um aspecto lúdico, sugere imagens, diálogos e possibilita múltiplas interpretações. Desse modo, as autoras defendem que esses aspectos devem ser explorados desde o primeiro contato do aluno com o instrumento. Com base nesse enfoque, os envolvimentos técnicos e interpretativos serão apresentados de "forma a permitir a vivência dos elementos musicais e suas várias possibilidades" (CURY; THIELE, 1997).

Após a apresentação do material, há um texto explicativo, direcionado ao professor, sobre as atividades propostas, tais como: transposição para as teclas pretas, dedilhado e dinâmica.

Em seguida, sob o título de O Método, partindo do Dó Central, são apresentadas as notas de referência em intervalos de $5^{\text {a }}$ nas Claves de Sol (Dó e Sol) e Fá (Dó e Fá), um desenho contendo os pentagramas das Claves de Sol e Fá sob o teclado (relacionando as notas nas pautas e a suas posições no teclado), as figuras rítmicas, sua subdivisão (semibreve, mínima, semínima e colcheia) e suas pausas. Os 42 exercícios são divididos em duas partes. Na primeira, do exercício 1 ao 19, a partir do âmbito determinado pelas três notas de referência (Dó, Fá na Clave de Fá e Dó, Sol na Clave de Sol), as autoras propõem exercícios de transposição para as teclas pretas, a variação de dedilhado e dinâmica. Na segunda parte, do 20 ao 42, ocorre a ampliação do âmbito das notas. A maioria dos exercícios contém a parte de acompanhamento escrita para o professor.

Os conceitos musicais apresentados, gradativamente, são: a leitura das notas nas claves de Sol e Fá, dinâmicas (forte, piano, mezzo forte, crescendo, diminuindo), o ponto de aumento, o legato, o staccato, sinais de repetição (barra de repetição e expressão $1^{\mathrm{a}}$ e $2^{\mathrm{a}}$ vez), a ligadura de valor, o tenuto, compassos simples quaternário (4/4), binário (2/2 e 2/4) e ternário (3/4), sinais de alterações (sustenido e bemol), indicação do pedal direito, rallentando e fermata.

\section{Repertório}

O livro apresenta um compêndio de 42 exercícios de dificuldades gradativas, de autoria das próprias autoras. 


\section{Atividades Criativas}

O método, inicialmente, aborda a leitura de notas por intervalos de quintas, partindo do Dó Central. Posteriormente, ocorre a ampliação do âmbito das notas. É necessário que o professor esclareça ao aluno sobre os conceitos musicais que serão trabalhados em cada exercício.

A presença de exercícios de transposição para as teclas pretas revela a preocupação das autoras em proporcionar, não somente o deslocamento dos dedos para outras teclas, mas o exercício "de ouvido", uma vez que o aluno deverá tocar meio tom acima, ou abaixo, daquilo que está escrito. Outras atividades poderão ser acrescentadas, uma vez que o material é composto apenas de exercícios.

\subsubsection{Toque piano hoje ...e sempre: curso de piano para adultos (BUCHER, 2009)}

\section{Conteúdo}

Com um CD de acompanhamento para as melodias propostas, o método é dividido em sete blocos.

O livro inicia-se com a apresentação do método pela autora. Nessa introdução, Bucher (2009, p. 5) relata que o conteúdo do método foi idealizado de um modo "que permite ao estudante e ao professor terem acesso natural e funcional às informações básicas dos fundamentos da música e do instrumento". Bucher (2009) explica, também, que mente, ouvidos, olhos e dedos atuam de forma integrada, pois "aquilo que a visão percebe em uma partitura deve ser reconhecido e assimilado pela mente para ser interpretado e ouvido de modo interno, gerando uma resposta motora, com consequente execução e avaliação auditiva".

Após essa introdução e a apresentação do índice, inicia-se o Bloco 1. Nesse primeiro bloco, é apresentado um breve histórico do piano e instruções gerais sobre como sentar perante o instrumento, a posição das mãos, os números dos dedos, os grupos de 2 e 3 teclas pretas, a semínima e mínima, o compasso, a barra divisória, a barra final e a leitura rítmica, com proposta de bater sobre uma mesa ou nas pernas. Sem apresentar a clave e a leitura de nota na pauta, inicia-se a leitura (fase de préleitura) dos exercícios e as melodias a partir dos grupos de 2 e 3 teclas pretas na mão esquerda e direita. Para a execução de cada melodia, os números dos dedos são indicados acima, ou abaixo, das figuras musicais (semínimas ou mínimas). Em 
seguida, são apresentados os nomes das notas musicais (ainda sem claves), o ponto de aumento, a barra de repetição e a semibreve.

No Bloco 2, inicia-se a leitura de notas nas claves de Sol e de Fá, em posição do pentacorde de Dó Maior, em ambas as mãos. São propostos vários exercícios gradativos de leitura nas claves, as pausas de semibreve, mínima e semínima e o compasso simples quaternário e leitura rítmica.

Nos blocos seguintes, os conteúdos trabalhados são os intervalos de $2^{a}$ a $8^{a}$, staccato, ritardo, acordes, cifras (C, F, G7) e suas inversões, ligadura, ostinato, dinâmica ( $p p, p, m f, f$, ff, crescendo e diminuendo), sinais de repetição (barras de repetição, D.C. al Fine, expressão $1^{\mathrm{a}}$ e $2^{\mathrm{a}}$ vez), acidentes (sustenido, bemol e bequadro), pedal de sustentação, colcheia, compassos simples binário e ternário, posição do pentacorde de Sol Maior e de Dó central, diferentes andamentos, semitom, tom, enarmonia, escala de Dó Maior e linhas suplementares superiores. $O$ método se encerra com o Bloco 7, finalizando com a peça Marcha em Dó Maior, de H. Berens (Op. 62, n. 5) a 4 mãos e um exercício de técnica.

\section{Repertório}

Além de peças da própria autora, o repertório de nível elementar conta com arranjos de melodias folclóricas e populares brasileiras, tradicionais estadunidenses e de outros compositores.

\section{Atividades Criativas}

O método apresenta pré-leitura nas teclas pretas e brancas, leitura por desenho melódico, intervalos melódicos e harmônicos, progressão de acordes, cifras e posições de pentacordes.

Apesar de não ser muito conhecido pelos professores de piano, é um método brasileiro de piano para adultos iniciantes significativo, pois, além de ser um dos poucos materiais brasileiros de iniciação ao piano voltado para o adulto, o repertório inclui várias melodias folclóricas e da música popular brasileira. Tal repertório familiar pode motivar o aluno ao reconhecer melodias do seu cotidiano.

O método não contempla atividades para compor ou criar, mas aspectos de leitura e interpretação da partitura. Propostas de atividades de criação poderão ser encontradas no Circulo das Quintas, material complementar da autora, mas que não foi analisado nesta pesquisa. Esse material propõe o conhecimento de pentarcordes, 
escalas, acordes, progressões de acordes, harmonização, transposição e improvisação.

Após o término desse primeiro volume, o aluno poderá prosseguir nos volumes 2 e 3 da obra Toque Piano Hoje. Além desses três volumes, a autora possui outros materiais didáticos que podem servir de complemento ao método, com os títulos Leitura à Primeira Vista, Harmonia Funcional Prática, Rearmonização e Ritmo com Ritmo, dentre outros.

\subsubsection{Adult Piano Adventures - A comprehensive piano course (FABER; FABER, 2009)}

\section{Conteúdo}

O método é dividido em 16 unidades e contém um CD para o acompanhamento das peças musicais.

No prefácio, os autores congratulam o aluno adulto pela decisão de estudar o piano e enviam a seguinte mensagem: "a alegria de fazer música não reside apenas em sua futura habilidade musical, mas também no presente processo de aprendizagem". Segundo os autores, o material foi elaborado para dar ao aluno as competências necessárias para executar uma quantidade significativa de músicas familiares.

Após o sumário, o livro inicia-se com a figura de um piano de cauda, indicando as partes do piano e uma breve explicação sobre as cordas, as teclas, os martelos e os três pedais.

A primeira unidade, intitulada Introdução para tocar, orienta, através de figuras e textos, como um adulto deve se sentar no banco do piano, a posição das mãos e o número dos dedos. A unidade propõe exercícios para trabalhar independência de dedos e como acionar o pedal direito do piano. Em seguida, é demonstrada a figura do teclado e as regiões (grave, médio e agudo), dinâmica ( $p$ e f) e propostas de exercícios para executar no teclado. Depois, apresenta a melodia (em processo de pré-leitura das notas) Amazing Grace, para ser executada em teclas pretas (grupo de 2 e 3), com acompanhamento escrito para o professor. Para a execução dessa melodia pelo estudante, os números dos dedos são indicados acima ou abaixo da letra da música, representando a mão de cima e a mão de baixo. Com a apresentação das figuras musicais (semínima, mínima, mínima pontuada e semibreve), a próxima melodia, em teclas pretas, é representada pelas 
figuras musicais com haste para cima ou para baixo (indicando mão de cima e mão de baixo) e com a indicação dos dedos.

Ainda na primeira unidade, várias melodias (em teclas brancas na posição de pentacorde de Dó Maior) são propostas. A pré-leitura ocorre através de figuras musicais, dos números de dedos e de letras (A, B, C, D, E, F, G) que são desenhadas dentro das figuras e correspondendo aos nomes das notas musicais. A unidade discorre com o estudo de intervalos sucessivos e simultâneos de segunda e terça, exercícios de transposição, a barra de compasso, a barra de repetição, atividades criativas através do uso do pedal direito e análise musical da peça (seções A, A', B, A'). A unidade termina com as seções Minuto de Técnica e Teoria Musical, com vários exercícios para dar o nome da nota correspondente à tecla assinalada, leitura rítmica a duas vozes e de improvisação nas teclas pretas com um acompanhamento escrito para o professor.

$\mathrm{Na}$ unidade 2, inicia-se a leitura nas claves de Sol e de Fá, partindo do Dó central. São apresentados os compassos simples ternário e quaternário, intervalos de segundas e várias melodias, além da indicação de diferentes intensidades e do legato, o uso do pedal direito nas peças, exercícios de transposição, percepção melódica e rítmica. Essa unidade se encerra com as seções Minuto de Técnica, explicando a linha de oitava e com exercício rítmico, e Teoria Musical, com a orientação de leitura, análise musical e exercícios para "treinar o ouvido", intitulado Ear Training.

Nas unidades posteriores, os conteúdos trabalhados são a leitura de notas, os intervalos sucessivos e simultâneos de $3^{a}, 4^{a}, 5^{\underline{a}}$ e $6^{a}$, as pausas, os sinais de repetição (D.C. al Fine, Coda, expressão $1^{\underline{a}}$ e $2^{\underline{a}}$ vez), os sinais de dinâmica, staccato, colcheia, fermata, pentacordes (Dó Maior e Sol Maior), acordes (C, Csus, F, G, Gus, G7), arpejos, passagem de dedos, diferentes andamentos, tom, semitom, sinais de alteração (sustenido, bemol, bequadro), escala de Dó Maior e Sol Maior (movimento paralelo e contrário, e os acordes I, IV e V7, em posição fundamental e inversão) e cifras. Seções com os títulos Creative, Discovery, Ear Training, Minute Technique e Music Theory estão presentes durante todo o material. O livro se encerra com um Dicionário Musical. 


\section{Repertório}

O repertório é composto por arranjos de melodias folclóricas e tradicionais estadunidenses de várias composições dos próprios autores e de compositores da música erudita europeia.

\section{Atividades Criativas}

O método apresenta uma abordagem de pré-leitura, leitura por intervalos, posições em pentacordes e de Dó central, melodia e acompanhamento por acordes, progressão de acordes e cifras. Além de práticas para o desenvolvimento da leitura musical, o método contém atividades de transposição, de improvisação, criação e de análise formal, da primeira até a última unidade.

É uma proposta de ensino muito relevante, pois agrega à leitura da escrita musical o desenvolvimento de habilidades aurais, através de propostas para exercitar "o ouvido", exercícios de transposição e atividades de improvisação e criação. No entanto, por estar escrito na língua inglesa, pode ser um empecilho para àqueles que não possuem familiaridade com a leitura no idioma em inglês.

\subsubsection{Upper Hands - A Method for Adults 50+ (SCHOEN, 2012)}

\section{Conteúdo}

O método, voltado para adultos, tem por objetivo potencializar as atividades cerebrais através de exercícios e práticas musicais no piano (SCHOEN, 2012).

Após a introdução, inicia-se o primeiro tópico com orientações quanto à postura, posição das mãos no piano e números dos dedos. Iniciando nas teclas brancas e na posição de Dó Central, o aluno começa a tocar pequenos trechos no piano, em movimento ascendente e descendente, com as notas Dó, Ré e Mi, indicadas, respectivamente, pelas letras C, D e E. Ainda nessa parte de pré-leitura, seções intituladas Brain Sharp apresentam atividades para exercitar o cérebro, como o exercício para o aluno tocar de memória um dos curtos trechos estudados.

Em seguida, exercícios semelhantes são indicados para a mão esquerda, em posição de Dó Maior, abaixo do Dó Central. Aqui, a seção Brain Sharp sugere que o aluno, de olhos fechados, toque com a mão direita as teclas correspondentes às notas Dó, Ré e Mi. Schoen (2012) explica que esse exercício utilizará o toque (sem o sentido da visão) e auxiliará o cérebro a desenvolver um "instinto" e perceber a distância entre as teclas. Posteriormente, um desenho mostra um teclado com 88 
teclas e a localização das sete notas musicais. Após esse desenho, outros exercícios são indicados para enfatizar as teclas correspodentes às notas, na seção Brain Sharp.

Os próximos conteúdos são as escalas de cinco sons (inicialmente a partir de Dó, mas no final, há um apêndice mostrando as escalas nos doze tons), ligadura, sustenido e bemol, figuras musicais (semibreve, mínima, mínima pontuada e semínima) e exercícios diversos para relembrar o conteúdo já estudado.

Na página 11, a pauta e as claves de Sol e Fá são apresentadas, seguidas pela fórmula de compasso, pela barra divisória, pela barra final e pelos sons enarmônicos no teclado. Exercícios para aprimorar a leitura das notas situadas nos espaços e linhas estão sempre presentes, somados à seção Brain Sharp, que fornece atividades para exercitar e desenvolver a memória, a leitura, a habilidade de escuta e espacialidade no teclado. Na página 20 , a autora propõe que o aluno crie uma letra para uma melodia pronta.

A seguir, várias peças (tonalidades de Dó Maior, Sol Maior, Ré Maior, Fá Maior) e exercícios trabalharão gradativamente a leitura de notas nas claves de Sol e Fá, as pausas (semínima, mínima e semibreve), as figuras de colcheias, mínimas e semínimas pontuadas, bequadro, sinais de repetição (barra de repetição, D.S. al Fine), expressão $1^{\mathrm{a}}$ e $2^{\mathrm{a}}$ vez, fermata, dinâmica ( $p p, p, m p, m f, f$ e $f f$ ), andamento (Largo, Andante e Allegro) e acordes maiores e menores.

Os conceitos musicais aprendidos são sempre revistos e reiterados, em formatos diversos, através de jogos musicais, como palavras cruzadas, dentre outros. O livro é encerrado com um apêndice, contendo os pentacordes maiores nos doze tons, formação de acordes maiores, menores e diminutos, exercícios para memorizar os acordes, exercícios de leitura, acordes (arpejados e em blocos), sempre apresentados através de figuras e desenhos explicativos. O livro ainda disponibiliza um endereço eletrônico para dicas e downloads gratuitos de partituras.

\section{Repertório}

O repertório, em nível básico, apresenta arranjos de melodias tradicionais e folclóricas estadunidenses, de compositores da música erudita europeia e da autora. 


\section{Atividades Criativas}

Esse método de piano é direcionado às pessoas com idade a partir de cinquenta anos (50+). Inicialmente, ele apresenta a fase de pré-leitura nas teclas brancas e na posição de Dó Maior, seguida pela leitura melódica nas claves de Sol e Fá, melodia acompanhada por acordes e cifras. Como trabalho de criação, a autora propõe que o aluno crie uma letra para uma melodia já existente. Esse material poderá ser complementado com outros tipos de atividades criativas.

Uma das características marcantes do método é reforçar a memória através da prática no piano e de diversas atividades (jogos mnemônicos, exercícios rítmicos e revisão dos conteúdos em modos diversos) que são propostas durante todo o material.

Com a fonte em tamanho maior comparada a outros materiais, o método se apresenta como uma opção para alunos adultos iniciantes no piano, com uma abordagem em nível elementar e reiteração dos conteúdos durante todo o método. Upper Hands - A Method for Adults 50+ já contém os volumes 2, 3 e 4.

\subsubsection{Dos métodos}

Quanto ao conteúdo dos métodos analisados, verifica-se que o método de Thompson (1943) apresenta um nível gradativo de dificuldade técnico-musical maior em relação aos métodos aqui analisados, ainda que em nível básico. O conteúdo musical é discorrido mais diretamente do que em outros métodos, que podem permanecer mais em um determinado conceito através de peças curtas ou de exercícios.

Os repertórios dos métodos analisados, em nível elementar, apresentam predominantemente uma estrutura harmônica simples, com notas de passagens favorecendo o aparecimento de curtas mudanças tonais através da progressão $\mathrm{V}-\mathrm{I}$, mas rapidamente retornando ao tom principal. Outras combinações sonoras poderão ser vivenciadas através dos exercícios de improvisação ou criação. Além de arranjos de peças do repertório erudito europeu, de compositores estadunidenses, composições próprias dos autores, melodias tradicionais e folclóricas de alguns países, temas do universo infantil ainda são encontrados em um e outro material. A presença de peças com temas infantis parece estar relacionada ao número significativo de peças musicais necessárias à elaboração do material e a recorrência, dos autores, às canções de domínio público voltadas ao público infantil, 
ou ainda, à intenção dos autores em inserir um repertório familiar. Tal aspecto pode ser favorável, ou não, para o aluno adulto, que poderá se sentir à vontade em tocar algo conhecido ou incomodado por se tratar de repertório com temáticas voltadas às crianças.

A respeito da presença de atividades criativas, o método que mais se desponta é o Adult Piano Adventures, de Faber e Faber (2009). Por abarcar, em um único material, diversos tipos de atividades musicais que se complementam (técnica, teoria, leitura, improvisação, criação musical, teoria, dentre outros), esse método se

apresenta com um número maior de páginas. É um material significativo para a aprendizagem de piano, oferecendo ao aluno momentos de leitura, interpretação, criação e improvisação, desde a iniciação ao piano.

\subsection{O piano em Ribeirão Preto}

Fundada em 1856, a cidade de Ribeirão Preto se situa a 313 quilômetros da capital, São Paulo. Nesse período, a região recebia muitos mineiros que saíam de suas terras já esgotadas para a mineração e procuravam pastagens para a criação de gado. Muitos se fixaram "próximo ao encontro de dois córregos: o Ribeirão Preto e o Retiro. Daí, formou-se o núcleo habitacional da atual cidade de Ribeirão Preto e sua comunidade" (HADDAD; FERRAZ Jr., 2013, p. 28).

A economia mineira passou a ser de roças de subsistências e de criação de gado. A cultura cafeeira chegou à região de Ribeirão entre 1860 e 1870 . Haddad e Ferraz Jr. (2013, p. 30) descrevem que:

As condições favoráveis de solo, clima e relevo, agregadas ao trabalho escravo, aumento de consumo de café, seu elevado preço no mercado internacional e o decadente cultivo no Vale do Paraíba - iniciado em 1825 fizeram crescer o plantio do café tipo Bourbon na região.

O cultivo de café foi a fonte de renda e a principal atividade econômica do Estado de São Paulo, transformando Ribeirão Preto no maior produtor de café do mundo. Essa realização deu à cidade o título de "Eldorado do Café". No entanto, em 1929, com a quebra da Bolsa de Nova York, a produção de café entrou em declínio (HADDAD; FERRAZ Jr., 2013).

Fernandes (2011) escreve que a partir das últimas décadas do século XIX, notícias sobre eventos e anúncios ligados à música passaram a circular em Ribeirão Preto, nos primeiros jornais da cidade, quase que diariamente. Os professores de 
música ofereciam, através de anúncio, aulas particulares de música, principalmente "de piano, canto, solfejo e teoria e instrumentos de cordas" (FERNANDES, 2011, p. 50). Além das aulas, anúncios de venda e manutenção de instrumentos, partituras, gramofones e discos eram muito frequentes. O que mais se destacava era 0 comércio de pianos. Ainda segundo Fernandes (2011, p. 53):

Tais anúncios eram repetidos diariamente por longos períodos que chegavam a meses, sem reformulação, ou anos, de forma alternada e com algumas modificações. Isso indica que o comércio de pianos deveria ser bastante expressivo, e esses instrumentos tinham a sua venda facilitada em diversas prestações ou clubes [...].Tantos pianos demandavam manutenção, que era realizada pelos afinadores e consertadores que passavam temporadas pela cidade, até se fixarem devido à frequência dos serviços.

A autora relata que possuir esse instrumento em casa representava status. Mesmo aqueles que não sabiam tocar poderiam ter uma "pianola" em casa para animar as reuniões e, ainda, usá-lo como um objeto de decoração na sala de estar.

Em 1915 já existia uma casa especializada em conserto e afinação de pianos e de outros instrumentos na cidade, como consta em um anúncio publicado no Jornal $A$ CIDADE, na edição de 15 de agosto de 1915, página 2, descrito por Fernandes (2011, p. 56): “Afinadores e concertadores de pianos, pianolas, autopianos, violinos, orgams, etc. - 112, Rua Duque de Caxias - Telephone 239 Ribeirão Preto. Attendem a chamados para o interior e fazendas".

Nesse cenário, destaca-se o comerciante de piano Belmácio de Pousa Godinho, que também era compositor, flautista e professor, pai da pianista e professora universitária de música, D. Dinah Pousa Godinho Mihaleff ${ }^{6}$, nascida em 1928. Desde 1919, o Sr. Belmácio atuava como comerciante de piano e partituras no estabelecimento A Musical, onde permaneceu por cerca de 60 anos à Rua General Osório (MARMIROLI, 2010). A professora, D. Dinah, ao falar sobre seu pai, relembra: "meu pai foi o maior vendedor de piano na época, as melhores recordações da minha infância foi essa vivência, ouvindo meu pai tocar sua flauta e compor no piano. Foi meu grande incentivador e modelo" (MARMIROLI, 2010, p. $52)$.

${ }^{6} \mathrm{D}$. Dinah é uma personagem importante no contexto do ensino do piano e tem atuado na formação de inúmeros instrumentistas e professores de piano em Ribeirão Preto. O trabalho "Música e Emancipação Feminina: Os relatos de Professoras de Piano em Ribeirão Preto-SP (1970-2000)", de Dalva Bueno Marmiroli, retratam acerca da vida e prática docente dessa professora. Vale salientar que vários professores de piano, participantes dessa pesquisa, relatam que tiveram aulas com a $D$. Dinah. 
A prática musical é uma atividade artística presente na história de Ribeirão Preto. As diversas formações vocais e instrumentais, como cantores, bandas, orquestra, instrumentistas, maestros, compositores e professores de música, foram e são contribuições relevantes para manter a frequência das atividades musicais nesta cidade.

Um levantamento referente à quantidade de escolas de música e de conservatórios existentes em Ribeirão Preto pode ser verificado no trabalho de Dimas Carte Araújo da Costa $^{7}$, realizado em 2010. As escolas particulares de música foram classificadas em pequenas, médias e grandes, de acordo com 0 número de alunos. Os dados apresentados apontam 32 pequenas escolas (de $10 \mathrm{a}$ 35 alunos), 25 médias escolas (de 35 a 60 alunos) e 13 grandes escolas (de 50 a 95 alunos). Os conservatórios ${ }^{8}$ na cidade somam sete. A pesquisa aponta, ainda, a existência de três espaços públicos (em que não é necessário pagamento pelas aulas de música) existentes: o Centro Cultural "Campos Elíseos", o Projeto Guri e o projeto de Percussão em escola da prefeitura. Além dos espaços não considerados como escolas de música (aulas de música ministradas por professores particulares na casa do professor ou na casa do aluno), há, na cidade, duas universidades, uma pública e outra privada, que oferecem a graduação em música (bacharel ou licenciatura), sendo a Universidade de São Paulo (USP) e a Universidade de Ribeirão Preto (UNAERP), respectivamente.

Nos diversos espaços e contextos de ensino e de aprendizagem de música em Ribeirão Preto, cidade com população estimada em $666.323^{9}$ habitantes, experiências e trajetórias musicais foram construídas e retratadas pelos sujeitos participantes dessa pesquisa.

\section{METODOLOGIA DE PESQUISA}

\subsection{Metodologia Qualitativa}

Com o propósito de investigar e compreender o cenário da prática de ensino de música para adultos iniciantes no instrumento piano na atualidade, a metodologia escolhida para essa pesquisa é a qualitativa.

\footnotetext{
7 Pesquisa feita dentro do projeto Orquestra Universitária, do DM/FFCLRP/USP, sob a orientação do professor Marcos Câmara de Castro.

8 Todos os conservatórios de música existentes na cidade são particulares.

${ }^{9}$ Disponível em: http://cod.ibge.gov.br/232AY. Acesso em: 17 Novembro 2015.
} 
A pesquisa qualitativa é definida como aquela que privilegia a análise de microprocessos através do estudo das ações sociais individuais e grupais. Ela realiza um exame intensivo dos dados, tanto em amplitude quanto em profundidade, e caracteriza-se pela heterodoxia no momento da análise (MARTINS, 2004). Além da flexibilidade quanto às técnicas de coleta de dados, Martins (2004, p. 292) afirma que:

A variedade de material obtido qualitativamente exige do pesquisador uma capacidade integrativa e analítica, que, por sua vez, depende do desenvolvimento de uma capacidade criadora e intuitiva. [...] A intuição aqui mencionada não é um dom, mas uma resultante da formação teórica e dos exercícios práticos do pesquisador.

De acordo com Brito e Leonardos (2001), os elementos que fazem parte dos processos da pesquisa qualitativa são o pesquisador, a literatura científica e o objeto/sujeito da pesquisa.

Acerca dos processos, bem como das relações estabelecidas entre esses elementos, as autoras relatam que "cada linha de pesquisa estabelecerá um diálogo específico entre cada uma dessas partes" (BRITO; LEONARDOS, 2001, p. 14). Sobre a relação pesquisador e literatura científica, as autoras enfatizam que um dos indicadores obrigatórios na descrição do trabalho de um pesquisador "é o tipo de literatura científica por ele consultado, utilizado ou citado em seus trabalhos, bem como as fontes que informam sua prática cientíica" (BRITO; LEONARDOS, 2001, p. 25). Sobre a relação pesquisador-objeto/sujeito da pesquisa, as autoras afirmam que ela diz respeito não só à maneira pela qual o pesquisador "se refere, em sua produção científica, às pessoas ou comunidades que estuda - tradução do respeito que Ihes manifesta e do estatuto que atribui ao seu papel na compreensão de suas práticas" -, mas ao elo entre o pesquisador e seu campo de pesquisa. Esse entendimento se "refere às relações das várias partes do estudo com a produção de dados/informações, que se preocupa com a ordem moral (regras, valores, prioridades, dadas às condições sociais e à ação individual) pressuposta na prática das ciências [...]" (BRITO; LEONARDOS, 2001, p. 27).

Além de revisão bibliográfica, outros aspectos constituíram a construção do trabalho de campo desse estudo, como a seleção e a delimitação do universo de sujeitos, a situação de contato, as técnicas de investigação para interrogar os participantes dessa pesquisa e a forma de análise dos dados. 


\subsection{Seleção e delimitação dos sujeitos entrevistados}

A partir dos objetivos desse estudo e do levantamento bibliográfico, foram elaboradas perguntas a serem aplicadas a dois públicos-alvo: professores que atuam na cidade de Ribeirão Preto no ensino de piano para alunos adultos iniciantes em aulas particulares, em escolas de cursos livres de música e em conservatórios, e alunos iniciantes de piano, com faixa etária entre 30 e 59 anos. As questões ${ }^{10}$ tiveram como foco aspectos da prática do ensino e da aprendizagem do piano para adultos iniciantes. $O$ convite aos professores e alunos adultos foi feito pessoalmente pela pesquisadora, por telefone ou por e-mail, de acordo com as possibilidades de acesso ao convidado.

Após o convite ser aceito pelo convidado (a), a pesquisadora contatou cada um, a fim de marcar a entrevista em um local indicado por ele (a). No entanto, a maioria escolheu responder as questões via e-mail. Assim, as respostas ${ }^{11}$ foram coletadas pessoalmente, durante a execução das entrevistas, e recebidas, também, via e-mail. Em ambas as situações, foram feitas as mesmas perguntas aos entrevistados. No contato inicial da entrevista, foram apresentados ao entrevistado dados sobre a pesquisadora, a instituição de origem e a proposta da pesquisa. Nesse momento, foi entregue o Termo de Consentimento Livre e Esclarecido (TCLE ${ }^{12}$ ), informando e esclarecendo acerca da pesquisa e sua participação. Além de assegurado o direito ao anonimato, ao acesso às gravações e às análises, o entrevistado poderia fazer as perguntas que desejasse.

As entrevistas foram registradas através de um programa de áudio, o Audacity, que permite gravar, importar e exportar diversos formatos diferentes de arquivos de áudio. Os participantes que escolheram responder às questões via email receberam as mesmas orientações descritas acima, juntamente com o TCLE.

A quantidade de sujeitos foi o resultado da "qualidade das informações obtidas em cada depoimento, da profundidade e do grau de recorrência e divergência dessas informações" (DUARTE, 2002, p. 143-144). A partir disso, a

10 Ver apêndices A e B.

11 Inicialmente, este trabalho contemplava realizar entrevistas de forma pessoal entre a pesquisadora e os entrevistados. No entanto, em virtude da maioria deles escolher a opção de envio das respostas por e-mail, as entrevistas tiveram perfil estruturado.

12 De acordo com a orientação da secretaria da PPGMUS-USP, foi necessário ter uma autorização do participante quanto à coleta de dados. A partir disso, foi elaborado o Termo de Consentimento Livre e Esclarecido (TCLE), que visa informar e esclarecer o entrevistado acerca da pesquisa, sua participação, permissão quanto à gravação da entrevista, além de assegurado o sigilo e anonimato na utilização dos dados coletados. 
amostragem de sujeitos foi composta por onze professores de piano (dez mulheres e um homem) e cinco alunos adultos iniciantes de piano (três mulheres e dois homens).

Cada professor participante dessa pesquisa foi identificado com a letra "P", sucedida de um número inteiro, por exemplo, P1. O aluno adulto foi identificado com a letra "A", sucedida de um número inteiro, por exemplo, A1. A idade de cada participante indica a idade que cada um possuía quando participaram da pesquisa.

\subsection{Os instrumentos de coleta de dados: entrevistas e questionários}

A coleta de dados ocorreu no período de junho a dezembro de 2014, através de entrevistas realizadas pessoalmente e de questionário enviado por e-mail. 0 questionário, como uma técnica de investigação, teve por objetivo "o conhecimento de opiniões, crenças, sentimentos, interesses, expectativas, situações vivenciadas etc." dos professores e alunos de piano participantes da pesquisa (GIL, 1999, p. 124).

Na execução das entrevistas, foi utilizada a entrevista de perfil estruturado, entendida como uma técnica de coleta de dados bastante adequada para obter informações das pessoas e que se "desenvolve a partir de uma relação fixa de perguntas, cuja ordem e redação permanecem invariáveis para todos os entrevistados" (GIL, 1999, p. 115-117). As entrevistas desse tipo podem assumir maior ou menor grau de estruturação em função do tipo de perguntas que aparecem nos formulários, que podem ser abertas ou fechadas. A escolha pela grande parte das questões com respostas abertas proporcionou ampla variedade de respostas, uma vez que "podem ser expressas livremente pelo respondente" (GIL, 1999, p. 118).

\subsection{Os participantes}

A pesquisa envolveu 16 participantes, sendo cinco alunos adultos iniciantes de piano e onze professores. Os quadros 2 e 3 apresentam um breve perfil pessoal e profissional de cada um dos participantes da pesquisa, sendo o primeiro voltado para a apresentação da idade, profissão, nível de escolaridade e preferência musical dos alunos. 


\begin{tabular}{|c|c|c|c|c|}
\hline Aluno(a): & Idade: & Profissão: & $\begin{array}{c}\text { Nível de } \\
\text { Escolaridade: }\end{array}$ & Preferência Musical: \\
\hline A1 & 57 anos & $\begin{array}{c}\text { Funcionária Pública da } \\
\text { Área da Saúde }\end{array}$ & Ensino Médio & MPB, samba e erudito \\
\hline A2 & 36 anos & Cabeleireira & $\begin{array}{c}\text { Superior } \\
\text { incompleto }\end{array}$ & $\begin{array}{c}\text { MPB, erudito, rock e } \\
\text { reggae. }\end{array}$ \\
\hline A3 & 51 anos & $\begin{array}{c}\text { Funcionário Público } \\
\text { Federal }\end{array}$ & Pós-graduação & $\begin{array}{c}\text { MPB, erudito, jazz e } \\
\text { bossa nova }\end{array}$ \\
\hline A4 & 44 anos & Protética & Ensino Médio & $\begin{array}{c}\text { MPB, sertaneja, } \\
\text { erudito e gospel. }\end{array}$ \\
\hline A5 & 48 anos & Eletricista & Ensino Médio & $\begin{array}{c}\text { MPB, sertaneja, rock e } \\
\text { gospel. }\end{array}$ \\
\hline
\end{tabular}

Quadro 2 - Perfil dos alunos participantes da pesquisa

Fonte: Elaboração da autora

Os dados do quadro 3 são formados pela idade e nível de escolaridade de cada um dos professores entrevistados.

\begin{tabular}{|c|c|c|}
\hline Professor & Idade & Nível de Escolaridade \\
\hline P1 & 51 anos & Bacharel em Piano (UNAERP) \\
\hline P2 & 37 anos & Musicoterapia (UNAERP) \\
\hline P3 & 55 anos & Licenciatura em Música (UNAERP) e Pedagogia \\
\hline P4 & 62 anos & Graduação em História (Faculdade Barão de Mauá) \\
\hline P5 & 40 anos & Mestre em Musicologia (UNESP), Doutoranda (USP) \\
\hline P6 & 50 anos & Bacharel em Piano e Licenciatura em Música (UNAERP) \\
\hline P7 & 33 anos & Bacharel em Piano (USP) e em Pedagogia \\
\hline P8 & 56 anos & Ensino Médio \\
\hline P9 & 28 anos & Licenciatura em Música (UNAERP) \\
\hline P10 & 40 anos & Licenciatura em Música, Piano Popular (UNAERP) \\
\hline P11 & 67 anos & Ciências Sociais \\
\hline
\end{tabular}

Quadro 3 - Perfil dos professores participantes da pesquisa

Fonte: Elaboração da autora

\subsection{Forma de Análise}

Após a coleta do material, iniciou-se a organização não estrutural das respostas enviadas por e-mail e a transcrição das entrevistas. As respostas dos participantes representam a fonte de dados utilizados na análise. Em seguida, procedeu-se a leitura desse material, a fim de colher "as impressões que o texto sugere e reunir as primeiras intuições que auxiliem na concretização de um plano de análise" (CHIZZOTTI, 2008, p. 129-130).

A análise escolhida foi a análise de conteúdo, visto que esta é uma das modalidades de interpretação de textos e parte do pressuposto, segundo Chizzotti (2008, p. 115-117), de que "um texto contém sentidos e significados, patentes ou ocultos, que podem ser apreendidos por um leitor que interpreta a mensagem contida nele por meio de técnicas sistemáticas apropriadas”. A mensagem pode ser compreendida, segundo o autor, "decompondo-se o conteúdo do documento em 
fragmentos mais simples, que revelem sutilezas contidas em um texto". Esses fragmentos podem ser palavras, termos ou frases significativas de uma mensagem. A mensagem apreendida "pode revelar a concepção do seu emissor, os seus valores, opções, preferências".

Em seguida, iniciou-se a fase de eleição das categorias. A categorização supõe a eleição das unidades de análise. As unidades de análise se referem à frequência material de cada elemento. Segundo Chizzoti (2008, p. 130-131), tais elementos podem ser "palavras, termos, trechos de frases, temas ou frases com significação", correspondentes às respostas dos participantes desse estudo. As unidades de análise foram reunidas e relacionadas em torno de categorias, "que confere unidade a um agrupamento de palavras ou a um campo de conhecimento, em função do qual o conteúdo é classificado, quantificado, ordenado ou qualificado" (CHIZZOTI, 2008, p. 117). Assim, foram eleitas quatro categorias: trajetória musical, razões para iniciar o estudo de piano na fase adulta, descrição da prática docente para o adulto iniciante de piano e experiências do aluno adulto com a aprendizagem do piano.

A última fase, a análise dos dados, tem relação com os objetivos da pesquisa e pressupõe, com base nos dados observáveis, que o pesquisador pode "fundamentar inferências que permitam afirmações consistentes, descobertas das realidades e interpretações fidedignas" (CHIZZOTI, 2008, p. 131). Essa fase, além de operar com conceitos e constructos do referencial teórico, trata de "produzir resultados e explicações cujo grau de abrangência e generalização depende do tipo de ponte que possa construir entre o microuniverso investigado e universos sociais mais amplos" (DUARTE, 2002, p. 152). 


\section{SOLILÓQUIOS E DIÁLOGOS NO PROCESSO DE ENSINO E APRENDIZAGEM DE PIANO NA FASE ADULTA ${ }^{13}$}

\subsection{Trajetória Musical}

As experiências e conhecimentos musicais ocorrem em contextos educativos diversos, que podem ser classificados como formais, não formais ou informais. Esses termos caracterizam modalidades onde os processos de educação e de aprendizagem transcorrem. Libâneo (2004) organiza esses termos em duas modalidades:

- A educação não intencional, também chamada de informal, que atua de modo disperso, difuso, não planejado ou não sistemático;

- A educação intencional, que se estende em educação não formal e formal e assume formas intencionais e sistemáticas.

Segundo o autor, a modalidade formal está relacionada à "educação estruturada, organizada, planejada intencionalmente, sistemática", como a educação escolar, mas não exclusivamente. Outros tipos de educação intencional podem abarcar a educação formal, como a educação de adultos, a educação profissional, dentre outros, "desde que nelas estejam presentes a intencionalidade, a sistematicidade e as condições previamente preparadas, atributos que caracterizam um trabalho pedagógico-didático", mesmo que realizadas fora do limite escolar propriamente dito. Assim, compreende-se que "onde há ensino (escolar ou não) há educação formal” (LIBÂNEO, 2004, p. 88).

A modalidade não formal "são aquelas atividades com caráter de intencionalidade, porém com baixo grau de estruturação e sistematização, implicando certamente relações pedagógicas, mas não formalizadas", como os trabalhos comunitários, as atividades de animação cultural e os equipamentos urbanos culturais de lazer (LIBÂNEO, 2004, p. 89).

Já a modalidade informal, segundo o autor, indica a "educação que resulta do 'clima' em que os indivíduos vivem, envolvendo tudo o que do ambiente e das

${ }^{13}$ Do latim soliloquium (solus - sozinho, e loqui - falar), a palavra solilóquio indica a fala de alguém consigo próprio (HOUAISS, 2010). Utilizado como um recurso dramático ou literário, no solilóquio, em oposição ao monólogo, o personagem retrata os seus pensamentos de forma coerente, sem se dirigir especificamente a alguém. Assim, compreende-se que esse termo é o mais adequado para retratar os aspectos de ordem subjetiva e interna dos entrevistados, como as razões, os desejos, as concepções e as ideias acerca da música e de seu estudo na fase adulta. Os diálogos, aqui, são compreendidos pelas relações, ações e interações com os contextos e ambientes vividos pelos professores e alunos adultos entrevistados. 
relações socioculturais e políticas impregnam a vida individual e grupal", sendo, portanto, de caráter não intencional. Isso porque essas relações educativas são "contraídas, independentemente da consciência das finalidades que se pretendem" (LIBÂNEO, 2004, p. 90).

As respostas dos participantes a respeito de suas formações e trajetórias musicais, em específico no instrumento piano, perpassam pelas modalidades informal, não formal e formal, através das várias experiências musicais vivenciadas em seus ambientes. Essas experiências são observadas de diversas maneiras: na prática do instrumento, antes mesmo do aluno receber orientação de um professor, através de aulas particulares de piano na casa do docente, em escolas de música e em tantos outros cursos de formação na área (cursos técnicos, superiores, pósgraduações, entre outros).

\subsubsection{Dos alunos}

A1 teve o primeiro contato com o piano quando era criança, mas sua irmã já tocava o instrumento. Entretanto, somente em 2012 começou a estudá-lo. $\mathrm{Na}$ família, a irmã e a filha tocam piano. Suas aulas de piano acontecem na escola de música. Há dois anos A1 tem aulas com sua atual professora.

A2 começou a dedilhar o teclado da mãe e a tocá-lo "de ouvido" aos 17 anos, quando ocorreu seu primeiro contato prático com o instrumento. Ela iniciou suas aulas particulares de piano na casa de sua professora, em 2012.

A3 começou a estudar piano em 2012, quando ganhou o instrumento de um amigo. Desde agosto de 2014 tem aulas de piano em uma escola de curso livre de música. Além das aulas de piano, participa das aulas em grupo de teoria musical, oferecidas pela mesma escola.

A4 iniciou os estudos de piano em 2010 e seu primeiro contato com o instrumento foi em 2008. Desde 2012, tem aulas em uma escola de música. Desde criança, sempre gostou do piano. No entanto, somente na fase adulta conseguiu realizar esse desejo.

A5 iniciou os estudos de piano em fevereiro de 2014, quando começou a ter aulas no conservatório de música. Além das aulas de piano, participa de um coral.

\subsubsection{Dos professores de piano}

Acerca da formação pianística, os professores relatam a sua trajetória musical. Sobre o seu percurso, P2 descreve: 
Comecei a estudar piano aos sete anos com uma professora particular. $\mathrm{Na}$ época, você fazia aula com alguém que te indicava. Depois de algum tempo ela abriu uma escola de música e eu continuei estudando lá. Posteriormente, fiz três anos de curso técnico no conservatório de música e, depois, a faculdade de musicoterapia (PROFESSOR 2).

No relato apresentado por P7, a mesma descreve que já iniciou o curso por diversas vezes durante o seu percurso instrumental:

Comecei a estudar piano aos seis anos de idade e, como meus pais se mudavam constantemente de cidade, eu fiz o "início" do curso por várias vezes, pois a cada novo professor uma maneira diferente de ensinar piano era introduzida. Posteriormente, fiz conservatório e me formei no curso técnico. $\mathrm{Na}$ faculdade, no curso de bacharel em piano, o professor Fernando Corvisier foi um divisor de águas em minha formação pianística e, também, pedagógica, bem como a professora Fátima (PROFESSORA 7).

Ao descrever sobre sua trajetória, P3 relembra que iniciou os estudos aos oito anos de idade, sendo Maria Ignês Damasceno sua professora de piano, principal responsável pelo seu gosto musical, e a professora Laís Leal pela contribuição pedagógica. Após o conservatório, fez licenciatura em Música. Participou de diversos cursos e oficinas, nas quais frequentou com grandes pianistas como Almeida Prado, Gilberto Tinetti, Amilton Godoy, Cesar Camargo Mariano e outros.

Já P1 teve iniciação ao piano em sua própria casa, com sua mãe, que também dava aulas de piano:

Iniciei com minha mãe aos quatros anos e. aos seis, comecei o curso de musicalização. Depois, fiz o conservatório, o curso de aperfeiçoamento na UNAERP e a graduação em instrumento nessa mesma instituição. Tive professores inesquecíveis como a minha mãe Meire Genaro de Sicco, Marinha Pileggi, Aparecida Emboaba, Gilda Montans, Dinah Godinho Mihaleff, Miguel Angel Scebba e Rafael dos Santos (PROFESSORA 1).

Com diversas pessoas da família ligadas à prática musical na igreja, P4 começou os estudos de piano com a idade de 6 anos com uma professora particular. Morando em Amparo (SP), terminou o curso técnico em um conservatório de música em Campinas, em 1980, e foi aluna da professora Olga Legro Turato. Conta que a diretora do conservatório era Olga Bisardo Normanha, sogra de José Eduardo Martins, irmão de João Carlos Martins.

Com seis anos de idade, P6 iniciou os estudos de piano através de aulas particulares. Fez o conservatório de música e a graduação em piano na UNAERP. Nesse período, foi aluna de piano da professora Dinah Pousa Godinho Mihaleff, juntamente com Miguel Angel Scebba, professor argentino e pianista. Mais tarde, fez 
um curso em Campinas com os professores José Gramani e Jorge Cisneiros. Ao retornar para Ribeirão Preto, cursou licenciatura em Música na mesma instituição, sendo formada em dois cursos de graduação: bacharel em piano e licenciatura em música.

Também com seis anos de idade, P8 iniciou seus estudos e terminou o curso técnico no Conservatório Musical de Mirassol, em 1976. Sua formação contempla vários cursos, como o de piano popular, com a professora Laís Leal, e o curso de teclado, com diversas professoras, entre elas Glória Machado e Clarissa Simões.

Com 13 anos de idade, P9 começou a fazer aulas de teclado em uma escola de curso livre de música, com a professora Carla Alirya Marques Assis. Ela considera essa professora uma presença marcante e significativa durante todo o seu percurso de formação instrumental.

Aos seis anos, P11 iniciou os estudos de piano no conservatório Carlos Gomes, na qual permaneceu até o nono ano, quando concluiu o curso técnico. Posteriormente, fez um curso de aperfeiçoamento de piano e de musicalização para crianças, com duração de dois anos, na UNAERP. Acerca de sua formação, a professora relata que fez vários cursos, com professores e compositores de outras cidades, como Magdalena Tagliaferro, Eudoxia de Barros e outros. Segundo ela, esses professores foram "importantíssimos naquela época. Todo ano, a cada três meses, havia masterclasses".

Comparando a idade padrão para o ensino de piano, geralmente aos seis ou sete anos, P10 relata que "começou tarde", aos doze anos de idade, com uma professora particular. Posteriormente, fez o curso técnico no conservatório, a graduação em piano popular e licenciatura em música pela UNAERP. Sobre os professores que foram significativos em sua formação, descreve:

[...] tive aulas de jazz com professores particulares de piano, como Mário Férez, Toninho Diniz, João Viviane, Murilo Barbosa e Mário César Pereira. E com a Regina Padovan, em piano erudito, no conservatório Heitor VillaLobos, e com Jaime Barbosa, em piano popular, na UNAERP (PROFESSORA 10).

Com nove anos, P5 começou o estudo do piano com uma professora particular. Aos doze, foi para conservatório e fez o curso básico e técnico. Dez anos após a conclusão do curso técnico, foi estudar piano popular na antiga escola "ULM" (Universidade Livre de Música - posteriormente Centro de Estudos Musicais Tom Jobim, em São Paulo). Vários professores fizeram parte de sua formação pianística 
e musical, como as professoras de piano Denise Borges de Lima Gasparotti, Laís Leal, Regina Célia Carmona e Maria Zeí Biaggioni, e o professor Júlio César de Figueiredo. Esses três últimos eram professores da antiga ULM.

Analisando as respostas dos professores entrevistados, verifica-se que a maioria deles possui formação superior na área de música. Dos onze professores entrevistados:

- Três possuem licenciatura em música (P3, P9, P10) e P10 possui graduação, também, em piano popular;

- Dois possuem bacharelado no instrumento (P1 e P7);

- Um possui graduação em Musicoterapia (P2);

- Um possui dois cursos superiores em música: bacharelado em piano e licenciatura em música (P6);

- Quatro tiveram a formação musical e pianística em aulas particulares de piano e no conservatório (P4, P5, P8 e P11), sendo que P5 possui pós-graduação em Música (Mestrado em Musicologia pela UNESP e doutoranda em Musicologia pela USP).

Outro aspecto a ser considerado, mencionado pela maioria dos professores participantes da pesquisa, é a aula particular de piano, citada como parte integrante da formação desses docentes. Tomanik (2011), ao estudar a trajetória de quatro professores de piano na cidade de Belo Horizonte, afirma que todos eles disseram iniciar seus estudos com professores particulares de piano.

Tal aspecto intensifica a importância do papel do professor particular de piano, ainda tão vigente, na formação de quem busca pelo estudo de um instrumento musical. Camp (1975 14 apud BOZZETO, 2004, p. 12), na década de 70, ressaltou que "se o ensino particular desaparecesse, não apenas faculdades e universidades seriam as únicas a sofrerem com esta perda, mas coros, igrejas, editoras e também fabricantes de piano".

Além da formação específica no instrumento, os caminhos da experiência com a docência foram indicados pelos professores entrevistados.

Para P1, que começou a dar aulas aos 15 anos de idade no conservatório Carlos Gomes, onde estudava, o curso de Educação Musical e o conhecimento das

${ }^{14}$ CAMP, Sandra Lee. The status of the private piano teacher in music education in select Southern central states. 1975. Ph. D. Dissertation (Music Education) - Indiana University, Indiana, 1975. 
propostas de pedagogos, como Edgar Willems, Carl Orff, Émile Jaques-Dalcroze, Violeta Gainza e Zoltán Kodály, somados a outros cursos sobre Pedagogia Musical, foram importantes para a sua formação docente.

Para P2, a própria prática, seguida pelos cursos e a graduação, fizeram parte de sua formação pedagógica:

No conservatório eles não preparam muito para a parte pedagógica, apesar
de que o curso técnico tem que habilitar o profissional. Minha parte
pedagógica foi na raça mesmo, comecei a substituir professores. Então
comecei a fazer cursos, viajei e comecei a pesquisar, com isso fui
conhecendo mais a parte pedagógica. Na musicoterapia também aprendi
muito na questão da psicologia do desenvolvimento, aprendi sobre o
desenvolvimento humano, porque é necessário ter essa noção também da
parte pedagógica. E na graduação em Pedagogia, você estuda sobre as leis
que tem no país, a questão da educação da psicologia, a forma de você
planejar a sua aula, a metodologia. Acho muito importante a pessoa ter
essa noção (PROFESSOR 2, grifo nosso).

A prática docente ao piano, de P5, se deu, inicialmente, pelo conhecimento que recebeu de sua professora:

\begin{abstract}
Minha formação pedagógica foi nenhuma a princípio. Depois de formada no conservatório, dava aulas espelhada na forma como minha professora fazia. Depois, com o tempo, tive cursos de metodologia Suzuki para piano, dentre outros cursos de reciclagem de professores, todos pagos por conta própria. [...] Acredito que meu trabalho pedagógico, esse que aplico com meus alunos, seja resultado dessa formação que tive, me espelhando em meus professores, e muita criatividade, pois cada aluno, ou sala de aula, tem um perfil, com características próprias. Então, tenho que me adaptar ao meio em que estou (PROFESSORA 5).
\end{abstract}

De acordo com P6, seus conhecimentos pedagógicos iniciaram com as atividades docentes, quando tinha 16 anos e ainda cursava o último ano do ensino técnico de piano, em 1981. "Era uma coisa bem caseira. Comecei a dar aula de maneira informal, depois que minha vizinha perguntou se eu poderia ensinar sua filha a tocar piano, pois ela queria aprender. Comecei assim". No entanto, ela salienta que, mesmo depois da graduação em piano, buscou vários cursos:

Todos os cursos que apareciam eu ia atrás. Aqui em Ribeirão, na região, eu ia a São Paulo, frequentava as oficinas de músicas. Buscando melhorar, porque eu já sabia que o meu caminho seria a parte pedagógica, pois o que mais me atraia era a educação musical. Eu me realizava e achava que eu tinha uma vocação para esse campo ai. Então, eu buscava muitos cursos, oficinas e palestras (PROFESSORA 6). 
O curso superior em Pedagogia e a participação em vários cursos foram fatores fundamentais na formação de P3, P4, P7 e P10:

Os professores, a faculdade de Pedagogia, vários cursos de iniciação pianística e a musicalização foram importantes em minha formação. No entanto, na maior parte, busquei dentro de mim, durante minha trajetória de docente musical, sempre procurando novos meios de envolver o aluno nessa arte maravilhosa (PROFESSORA 3).

Paralelo ao curso de piano no conservatório, fiz o curso de magistério, na década de 70. Minha prática docente foi direcionada pelos conhecimentos aprendidos no curso de magistério quanto aos aspectos pedagógicos, no sentido, também, de orientar os alunos como pesquisar, uma vez que não existia a tecnologia que existe hoje. Eram livros. Não eram apostilas, nem xerox, já que era proibido fazer cópias (PROFESSORA 4).

Após terminar o conservatório, comecei a lecionar piano, pois no curso técnico havia tido algumas aulas de pedagogia do piano. Mas, por trabalhar, também, com musicalização e, apesar de ter feito vários pequenos cursos ligados a esse assunto, senti a necessidade de cursar Pedagogia. Foi um curso que me acrescentou bastante e me deu uma ótima base pedagógica (PROFESSORA 7).

Fiz magistério na instituição Moura Lacerda, um ano de Pedagogia na mesma faculdade, curso de extensão pedagógica musical no conservatório Heitor Villa Lobos e licenciatura em música na UNAERP (PROFESSORA 10).

A presença dessa disciplina durante o curso de piano no conservatório também foi ressaltada por P8 e P11. "A pedagogia no conservatório e a constante atualização no decorrer dos anos foram importantes para a minha formação pedagógica", declarou P8. Para P11:

A pedagogia incluída era de acordo com a grade curricular do conservatório. Naquele tempo, a gente tinha [...] pedagogia nos cursos técnicos. Eles tiraram a pedagogia, eliminando-a da grade curricular, ficando diferente. Após um tempo de formada, continuei dando aula no Conservatório Carlos Gomes e tínhamos muitos cursos com professores e compositores de fora. $\mathrm{E}$, então, eu tive muita bagagem com esses workshops. A diretora fazia muito, trabalhava bastante nisso.

Experiências de prática docente também podem ocorrer quando um aluno mais adiantado no piano atua como auxiliar de seu professor para os demais alunos aprendizes. Segundo Bastien (1973, p. 21), ao trabalharem com um professor experiente, seja observando ou trabalhando como assistentes, os alunos "terão uma visão real sobre as situações de ensino e a oportunidade de descobrirem se realmente gostam de ensinar". Essa situação é verificada nos relatos de P4, P5 e P9. 
Antes de concluir o conservatório, era assistente da professora. Eu ia até a casa dela para dar aulas para seus alunos pequenos. Quando terminei o conservatório, já tinha a experiência de ensinar para crianças. Foi um período de formação muito importante. Depois de formada, dei aula em Amparo, indo às casas de alguns alunos que eram da professora, na qual ela havia passado para mim. Foi um período muito interessante, pois eu atuava como assistente também (PROFESSORA 4).

Com 13 anos de idade, P5 iniciou suas atividades como professora de piano, ajudando sua professora que tinha muitos alunos. Essa mesma trajetória foi descrita por P9:

\begin{abstract}
Minha professora me deixava dar aula na escola, de modo experimental, para os iniciantes. Ela, sem dúvida, foi a principal contribuição em minha formação musical. Eu fiz curso extra com ela também, de musicalização infantil, porque na faculdade tínhamos esse embasamento, mas eu incrementava fazendo outros cursos com ela. Ela me passou bastante coisa para eu poder fazer com as crianças (PROFESSORA 9).
\end{abstract}

A formação para a docência desses professores, técnicos, licenciados ou bacharéis, se iniciou quando começaram a ministrar aulas, ainda quando eram discentes no instrumento, tendo seus professores como exemplos. A formação foi acontecendo durante todo o percurso de atuação e através de diversos cursos dos quais participaram.

Acerca da iniciação à prática docente, os professores entrevistados no trabalho de Tomanik (2011, p. 25-27) relataram que "os professores que tiveram foram importantes como referências pedagógicas, além da troca de experiências e observações de aulas dos colegas atuantes na área". Assim, os professores demonstraram "a sua longa prática pedagógica precoce", o que intensifica a ideia de que, "pondo a mão na massa", a formação para a prática do ensino foi ocorrendo.

A experiência com a prática docente em curso de formação instrumental pode ser verificada no trabalho Aprender através do ensino: investigando o que alunos do conservatório aprendem a partir do ensino para adultos mais velhos iniciantes ${ }^{15}$, de Perkins, Aufegger e Williamon (2014). Através do projeto Rhythm for Life, da Royal College of Music, no Reino Unido, os alunos do conservatório deram aulas de piano e violão em grupo, durante 10 semanas, para alunos iniciantes, da comunidade, com a idade entre 46 e 90 anos. Perkins, Aufegger e Williamon (2014, p. 2) defendem que "construir e manter uma carreira musical requer o contato com vários campos

15 Título original: Learning through teaching: Exploring what conservatoire students learn from teaching beginner older adults. 
que vão além das fronteiras tradicionais da carreira", ou seja, de atuar apenas como instrumentista. Segundo os autores, os conservatórios estão cada vez mais reconhecendo a necessidade de dotar os alunos com habilidades, conhecimentos e atitudes que serão exigidos ao longo da carreira dos músicos, como o trabalho em diversos contextos educativos. Esse tipo de experiência, por exemplo, pode oferecer um espaço para estudantes de música que estejam em processo de formação instrumental a se envolverem em processos de ensino e aprendizagem que os encorajam a ampliar as suas possibilidades profissionais, bem como trabalhar a iniciação ao instrumento com pessoas em diferentes faixas etárias, como os adultos e idosos.

A busca e a participação em diversos cursos de formação na área, de igual modo, são retratadas pelos professores participantes dessa pesquisa. A necessidade constante de pesquisas por parte dos professores é intensificada por Stateri (2014), onde o professor de música que não possui essa postura estará prejudicando não somente a sua carreira, mas os seus alunos também. Em suas palavras, Stateri (2014, p. 19) diz:

\footnotetext{
É importante lembrar que, com a criação dos cursos superiores em música, principalmente com os de pós-graduação [...], a pesquisa tornou-se ainda mais necessária, levando os profissionais a aderirem a essa prática, inclusive aqueles mais antigos, de formação mais tradicional.
}

Essa questão remete a um dos desafios da carreira docente, como a necessidade de se ter em mente que o caminho da docência é construído por constantes eventos e não termina com o curso na faculdade. Afinal, "para entender o mundo que hoje se desponta, é bom ter claro o seguinte: a educação não termina no último dia do ensino profissional ou do curso superior - nem nunca" (RIBEIRO, 2014). A busca por conhecimentos vários, durante toda a vida, não é uma particularidade dos que atuam na docência. Essa realidade abrange todos aqueles que procuram aprender saberes diversos, segundo as suas necessidades e objetivos específicos, numa perspectiva de aprender por toda a vida, tais como os alunos adultos iniciantes de piano na atualidade.

\subsubsection{Atuação dos professores de piano}

O tempo de atuação dos professores varia de 14 a 48 anos. Algo comum verificado nas respostas é que esses docentes não atuam somente como 
professores de piano em aulas individuais, mas em outras aulas de música, tais como teoria e percepção musical, história da música brasileira, teclado, flauta doce, coral (infantil, adulto e de terceira idade), técnica vocal, musicalização infantil, violão e orquestra infantil e juvenil.

Entre os locais de atuação mencionados, destaque para as escolas de música, com sete respondentes que confirmaram usar esse local para ministrarem o ensino. Em segundo lugar, entre os locais de atuação mais indicados pelos professores, ficou a própria casa deles. Os conservatórios ocuparam a terceira posição. As respostas podem indicar mais de um local de trabalho, como demonstrado no quadro 4 abaixo:

\begin{tabular}{|c|c|}
\hline Local de atuação: & Professor: \\
\hline Escola de música & P2, P5, P6, P7, P8, P9, P10 \\
\hline Em casa & P1, P4, P7, P8, P9, P11 \\
\hline Conservatório & P1, P3, P4, P6, P8, P10 \\
\hline Educação Básica & P2, P3, P6 \\
\hline Ensino Superior & P5 \\
\hline
\end{tabular}

Quadro 4 - Relação professor e locais de atuação

Fonte: Elaboração da autora

Atuar como docente em diferentes modalidades de educação e aprendizagem e para faixas etárias diversificadas implica em compreender os vários aspectos de aprendizagem do público-alvo, tais como a faixa etária, as experiências, as necessidades e os objetivos para com a aprendizagem.

\subsection{Razões para iniciar o estudo de piano na fase adulta}

A escolha por aprender a tocar um instrumento é instigada por fatores motivacionais intrínsecos e/ou extrínsecos (HENTSCHKE et. al, 2009; ARAÚJO, 2015, TOMANIK, 2011). As motivações provenientes de fatores extrínsecos são caracterizadas pelos estímulos dos ambientes e contextos vividos, os fatores internos, ou intrínsecos, pelas "necessidades, aptidões e interesses" pessoais (ALBUQUERQUE, 2011, p. 22).

Alunos adultos possuem razões pessoais e esperam atingir determinados objetivos ao buscar pelo estudo do instrumento nessa fase da vida. Ao conhecer os motivos de seus alunos, o professor poderá elaborar a sua proposta de ensino, 
considerando as suas necessidades e particularidades. À vista disso, essa categoria ${ }^{16}$ busca conhecer tais questões a partir das respostas dos entrevistados.

A motivação para estudar, indicada por A1, está relacionada ao seu desenvolvimento pessoal. Sua expectativa para com o estudo de piano é a de interagir mais com as pessoas através da música.

As aulas de piano são realizadas por A2 com foco na realização pessoal. Quanto às suas expectativas, é a de "levar a música para outras pessoas", como indica:

Eu pretendo, quando começar a tocar mesmo, como diz a minha professora: "demora, mas um dia eu chego lá", é levar a música para as pessoas mais necessitadas. Tenho uma amiga que me chamou para desenvolver um trabalho social com pessoas deficientes. E eu gostaria de atingir a alma das pessoas, como a música me atinge, e poder levar isso. Se eu conseguir, quero levar um instrumento e tocar um pouquinho para eles nesses espaços, ou em qualquer lugar, seja na família mesmo (ALUNA 2).

Para A3, a sua motivação é "estar bem para realizar coisas que the tragam prazer". Ele não pretende abandonar o estudo e justifica: "primeiro, porque é um hobby e serve como terapia e, segundo, porque o prazer de sentir a música sendo explorada ou reproduzida por mim é indescrítivel".

Com o desejo de fazer aulas de piano desde criança, A4 revela que somente na fase adulta teve essa oportunidade. Suas expectativas estão em tocar para si mesma e, "talvez, na igreja".

Ao assistir uma cantata de Natal em uma igreja evangélica, A5 sentiu-se motivado a tocar. Ele conta que a partir desse momento teve vontade de estudar música e tocar um instrumento. Em suas palavras, "a música é uma motivação para o meu estudo".

Dos alunos entrevistados nesta pesquisa, os objetivos de A5 para com o estudo do piano se destaca em relação aos outros. Em suas palavras, ele diz:

Quero ser maestro. Quero ensinar música, tocar junto, cantar e reger um grupo. Quero tocar em uma banda. Quero formar uma banda com a minha

16 Vários estudos apresentam diversas teorias para entender a motivação e suas relações na aprendizagem musical (HENTSCHKE et. al, 2009; ALBUQUERQUE, 2011; TOMANIK, 2011; ARAÚJO, 2015). Entre essas teorias estão a Teoria da Autodeterminação, a Teoria da Expectativa-Valor, a Teoria do Fluxo e a Teoria da Autoeficácia e Autoregulação. No entanto, não é o objetivo principal do presente estudo apresentar as teorias sobre a motivação, mas apontar os aspectos motivacionais, provenientes de fatores internos e externos, e sua interação, como aspectos relevantes para a apreensão de conhecimentos técnico-musicais na aprendizagem do piano por parte de alunos adultos iniciantes. 
família, cada um no seu instrumento. Através do piano, por ser um instrumento mais completo, teria acesso a outros instrumentos. Nunca é tarde para começar.

Os professores entrevistados revelam as motivações que seus alunos apresentam quando iniciam o estudo do piano. Dentre elas, é possível identificar algumas comuns, até mesmo ligada à recomendação médica, como apresentadas no quadro 5:

\begin{tabular}{|c|c|}
\hline Docente: & Motivações dos alunos apontadas pelos docentes: \\
\hline P1 & $\begin{array}{l}\text { - Realização de um sonho antigo; } \\
\text { - Desejo de tocar para amigos; } \\
\text { - } \text { Desejo em saber ler a partitura, pois participa de coral na igreja; } \\
\text { - Para espairecer; }\end{array}$ \\
\hline P2 & $\begin{array}{l}\text { Para relaxar, por prazer; } \\
\text { - } \quad \text { Desejo em tocar na igreja. }\end{array}$ \\
\hline P3 & - Gosto pessoal. \\
\hline P4 & $\begin{array}{l}\text { - Estabilidade no trabalho, permitindo a realização do curso (antes, a } \\
\text { dedicação à faculdade ou ao trabalho, ou a falta de condições financeiras, } \\
\text { impediam a realização do curso). }\end{array}$ \\
\hline P5 & $\begin{array}{l}\text { - Por indicação médica; } \\
\text { - Tocar na igreja. } \\
\text { - Gosto pessoal. }\end{array}$ \\
\hline P6 & - Realização de um sonho antigo. \\
\hline P7 & - $\quad$ Por prazer. \\
\hline P8 & - Gosto pessoal. \\
\hline P9 & $\begin{array}{l}\text { - Para relaxar; } \\
\text { - Por prazer; } \\
\text { - Realização de um sonho antigo; } \\
\text { - Para agradar a si mesmo. } \\
\end{array}$ \\
\hline P10 & $\begin{array}{l}\text { - } \quad \text { Gosto pessoal; } \\
\text { - } \quad \text { Realização de um sonho antigo. }\end{array}$ \\
\hline P11 & $\begin{array}{l}\text { - Desejo em aprender a tocar; } \\
\text { - } \quad \text { Desejo em aprender a tocar em casa. }\end{array}$ \\
\hline
\end{tabular}

Quadro 5 - Motivações dos alunos descritas pelos docentes

Fonte: Elaboração da autora

Acerca do que os alunos adultos esperam com o estudo do piano, P5 destaca que "eles sabem que não serão o pianista do teatro municipal e, uma vez que conseguem tocar qualquer música que os agradem, ficam felizes".

Já P3 conta que os alunos "chegam achando que já vão tocar" e, por isso, consideram que o professor deve ir ao encontro das expectativas de seus alunos. Sua postura é deixar o aluno "explorar o piano, descobrir os sons, tocar músicas que conhece, pois a maioria entra no estudo do piano na intenção de tocar as músicas que gosta". 
Segundo P4 e P11, respectivamente, "as expectativas dos alunos são muito fortes, se emocionando, às vezes, quando conseguem tocar uma peça inteira", ou "querem muito tocar, tocar em casa, mas não têm tempo para se dedicarem ao estudo fora das aulas de piano". Para P8, "geralmente, os alunos possuem poucas expectativas no início do estudo, pois não acreditam que vão conseguir de fato. No decorrer do curso, isso vai se contradizendo. Eles vão adquirindo confiança, disciplina, prazer e alegria contagiante". Sobre o apoio do professor quando o ânimo diminui, $\mathrm{P} 10$ relata:

Os alunos acham sempre que a aprendizagem do instrumento será rápida, mas com o tempo e as dificuldades da parte motora, se cobram muito. Tenho que estar sempre dialogando com eles, mostrando que essas dificuldades são naturais. Digo que eu mesma já passei por isso. Estou sempre mostrando suas melhoras e conquistas, sempre elogiando muito cada uma delas. Isso faz com que se sintam muito felizes!

As respostas dos entrevistados a respeito das motivações para iniciar o estudo de piano indicam entusiasmos provenientes da interação entre os fatores motivacionais de ordem intrínseca, como a realização e o desenvolvimento pessoal, o prazer, dentre outros, e extrínseca, relacionados ao seu ambiente, como os objetivos de ensinar música ou tocar em uma banda, para a família ou para outras pessoas. Assim, verifica-se que as razões para iniciar as atividades musicais, aqui através do piano, apresentam um conjunto de relações entre o aluno, a prática musical através do instrumento e o seu ambiente ou contexto vivido. No entanto, as respostas apresentam momentos de ausência de ânimos no decorrer desse processo. Não só o desânimo pode ocorrer, em virtude do aluno considerar que tocar piano não é uma atividade tão fácil de ser realizada, mas outros desafios próprios da prática docente, como a escolha de materiais didáticos ou o modo como é apresentado os conteúdos.

Tais desafios se apresentam como fatores que promovem desânimos. Além disso, as particularidades da realidade adulta, como as responsabilidades e as preocupações, podem afetar o processo de aprendizagem.

Nesse percurso, é importante a compreensão e o incentivo por parte do professor, pois o modo como o docente conduz as situações adversas em sala de aula pode levar o aluno a prosseguir, ou não, com o seu estudo de piano. 


\subsection{Descrição das práticas docentes para adultos iniciantes de piano}

Quem ensina? Como vai ensinar? Quais os objetivos do ensino? Quais os métodos que vai utilizar para fazer com que o aluno aprenda? Você tem que ter essas estratégias, para dar um ensino de qualidade. Não é apenas chegar e dizer eu vou dar aula hoje; tudo tem que ser pensado (PROFESSOR 2).

Das diversas questões que fazem parte da prática docente, estão os conteúdos e as maneiras de ensinar. Penna (2012) retrata que "o ensinar" consiste em uma atividade bastante complexa, sendo necessário dar uma forma (como e o modo de ensinar) ao conteúdo que se ensina (o que ensinar). Esses dois aspectos requerem do professor o mesmo cuidado, "pois o mero conhecimento do conteúdo é tão inútil pedagogicamente quanto habilidades (para ensinar) sem conteúdo" (PENNA, 2012, p. 14). Assim, a seleção e a organização dos conteúdos devem estar de acordo "com a capacidade cognitiva e interesses dos alunos". A motivação é outro aspecto a ser considerado na prática docente. Segundo a autora, o professor deve planejar atividades que favoreçam a motivação dos alunos e, ao mesmo tempo, permitam o desenvolvimento de suas competências.

A fim de conhecer o conteúdo das propostas de ensino e os modos de ensinar para alunos adultos iniciantes, esta seção retrata sobre os programas de ensino, a escolha dos materiais didáticos, os tipos de repertórios e os modos de ensino e aprendizagem daqueles que vivem essa realidade: o professor e o aluno de piano, em especial os participantes dessa pesquisa.

\subsubsection{Programa de ensino do piano para adultos}

[...] é sempre necessário pensar no fator das diferenças individuais, pois cada aluno apresenta condições mentais, físicas, sociais e afetivas de forma e graus diferentes. É preciso saber respeitar essas diferenças e conhecer 0 que as motivam (STATERI, 2014, p. 25).

As propostas de ensino de piano devem considerar as particularidades do público-alvo, seus objetivos, suas necessidades e os saberes necessários para a prática no instrumento. A partir disso, o professor poderá "prever as atividades necessárias projetadas para que os objetivos sejam alcançados, o que implica em tomada de decisões envolvendo aqueles que participam e os recursos materiais necessários" (STATERI, 2014, p. 69). 
A respeito das propostas de ensino, as respostas dos alunos adultos participantes dessa pesquisa mostraram realidades semelhantes, onde seus perfis e objetivos foram considerados pelo docente:
"O professor analisa as minhas dificuldades e objetivos e monta um plano segundo esses critérios" (ALUNA 1);
"Todos os estudos são definidos pela professora, mas posso levar algumas músicas que gosto para tirar nas aulas de piano" (ALUNA 2);
"A princípio, exposta a minha pretensão, a professora me propôs um método para atingir esse fim e eu aceitei" (ALUNO 3);
"Os estudos são definidos de acordo com a necessidade do aluno e visando o estudo geral do piano" (ALUNA 4);
"O programa apresentado pelo professor é aberto à mudanças" (ALUNO 5).

Para P1, existe uma lista de métodos que deve ser seguida para alunos que estudam em conservatórios, mesmo para os que estão no curso livre. No entanto, sobre o programa seguido em casa, a mesma relata que esse método:

[...] acaba sendo diferenciado um pouquinho. Quanto aos métodos, a gente usa os mesmos. Às vezes é assim. Você fica mais livre para trabalhar em casa. Em casa, você atua como professor particular, ficando mais livre para trabalhar. No conservatório, sempre tem que cumprir aquilo que está escrito ali (PROFESSORA 1).

Já P4 adota para seus alunos particulares em casa o mesmo programa de ensino proposto no conservatório. O conteúdo compreende pentacordes, escalas, acordes, arpejos (em todas as tonalidades), métodos pianísticos e peças de diversos compositores e enfatiza que, no conservatório, os coordenadores são flexíveis. Para P4, "tem aluno que tem bastante dificuldade de tocar um Bach [...], então, eu posso trocar por outro compositor do período barroco na qual seja mais fácil, menos complicado que Bach".

$\mathrm{Na}$ opinião de $\mathrm{P} 3$, o programa de ensino de piano em aulas particulares, em escolas de cursos livres de música e em conservatório são diferentes. Para alunos adultos, no conservatório onde trabalha:

"Os métodos [impresssos] são os mesmos aplicados com as crianças. A meu ver, não importa a idade, pois, no início, todos são crianças em relação ao aprendizado. Na escolha do repertório das peças, os diferencio de acordo com a vivência musical de cada um" (PROFESSORA 3). 
Para P5, a diferença entre o programa do conservatório e o aplicado em cursos livre está na flexibilidade. No conservatório, "precisamos cumprir o conteúdo programático imposto para a formação". Já em cursos livres de música, "o conteúdo é definido de forma personalizada quanto ao repertório, buscando estudo das escalas e de peças de técnica".

Atuando em uma escola de música, P2 diz que não existe um programa definido, mas gosta de "trabalhar passo a passo". O conteúdo a ser trabalhado envolve escalas, tríades, arpejos, materiais didáticos (métodos pianísticos e peças avulsas), conteúdo similar ao do conservatório em que trabalha a Professora 4.

Citando alguns parâmetros, P6 considera que as propostas para o ensino de piano devem:

Ter a parte técnica, a parte de sensibilidade, de interpretação e uma parte teórica que ele [o aluno] tem que decodificar. Ele precisa entender aquele código novo, aquela linguagem. Tento seguir este três parâmetros: a técnica, a decodificação da linguagem e a interpretação. Eu vínculo isso naquilo que o aluno veio buscar (PROFESSORA 6).

Ainda para P6, é preciso considerar "o que eles [os alunos] trazem também. Por mais simples que seja a música, sempre tem alguma coisa para você trabalhar, seja uma divisão de compasso, alguma coisa acha-se ali para trabalhar". E acrescenta: "vou aonde ele gosta. Eu nunca digo NÃO. Não sou fechada, mas tenho que mostrar tudo para ele, inclusive o mundo da música erudita, que também é muito encoberto". A partir dessa visão de ensino que considera importante, a professora conseguiu liberdade nos conservatórios e nas escolas onde trabalha:

\footnotetext{
No ambiente em que trabalho há muitos anos, a gente vai conversando e as pessoas vão confiando. Os meus superiores, as pessoas a quem eu devo uma resposta, me dão liberdade. Eu não preciso ser diferente em outro lugar (PROFESSORA 6).
}

Se P6 possui liberdade para trabalhar com os seus alunos em conservatórios e/ou escolas, para P7, "nas escolas [de música] existem certa pressão quanto a resultados que, talvez, não exista na aula particular". Acerca das propostas de ensino, P7 considera “importante já 'tocar' desde a primeira aula. Então, apresento o piano, a leitura relativa e, nas próximas aulas, as claves, notas, figuras musicais, sistema e assim por diante" (P7).

Para P8, o programa de ensino deve respeitar as necessidades, potencialidades e gosto musical dos alunos. Ela considera que, atualmente, não 
existem diferenças entre o programa desenvolvido em aulas particulares, em escolas de música e/ou conservatórios.

Segundo P9, em nenhum dos lugares em que trabalha tem um programa imposto. Ela declara que o programa não é definido pela escola e sim pelo professor:

“[...] não temos um programa montado. Temos livros disponíveis, porém nós fazemos [o programa]. Sigo mais ou menos o que me foi passado na faculdade pela maneira de ensinar, mas eu não tenho um programa diário. Eu mesmo que faço... Eu o divido em três períodos: o Básico, o Intermediário e o Avançado [...] Tenho os exercícios e os repertórios que o aluno precisa (PROFESSORA 9).

Para P10, o programa, basicamente, contempla técnica, leitura, teoria e recreativos. No entanto, considera que há diferença nos programas, dos espaços em que atua ou atuou: "já trabalhei em escolas em que os professores eram obrigados a utilizar os métodos que a dona da escola queria". Segundo a professora entrevistada, "isso não leva em consideração a individualidade de cada aluno e limita muito o aprendizado. Dificulta muito".

Por outro lado, "existem, também, conservatórios que investem muito em material didático. Em minha realidade, tenho muito mais acesso a materiais no conservatório do que na escola livre".

Com experiência no ensino de piano em conservatório, P11, atualmente, leciona em casa. O programa que segue é "normal, igual a um programa comum". Nesse sentido, P11 explica:

Você dá um exercício de técnica, ensina as escalas [...], primeiro de mãos separadas, depois, você vai juntando as escalas: primeiro uma escala, depois, duas escalas, depois, três escalas... Você entende né? E aí você vai seguir os exercícios de um livro, ou de dois ou de três livros. Depois, você pode pegar o programa de um livro que é mais interessante que o do outro. Você pode ir misturando. Você não precisa dar o livro do número um até o último. Você precisa ir pesquisando para saber o que é mais funcional para aquele aluno $[\ldots]$.

Atenta à questão da singularidade dos alunos, a professora continua, enfatizando que:

Você precisa saber o que é melhor para aquele aluno. Você não pode seguir um programa exatamente igual para todos. Você precisa variar. Se você der para todos [...] as mesmas coisas, de repente, um livro é bom para um e, para outro, pode ser muito chato (PROFESSORA 11). 
De acordo com as respostas, quanto aos programas de ensino nos conservatórios de música, não há um consenso entre os professores entrevistados. Para alguns, se o programa apresenta flexibilidade, para outros, há uma cobrança para que ele seja seguido. Já nas escolas de música (de cursos livres), em sua maioria, não há um conteúdo definido, ficando a responsabilidade para o professor. Nesse caso, o professor poderá elaborá-lo de acordo com a especificidade e objetivo do aluno, o que ocorre, também, na casa do professor, onde há mais abertura quanto às propostas de ensino para os alunos.

Outro indicativo apresentado nas respostas aponta que o modelo de programa de ensino conservatorial, contendo uma lista de estudos, métodos ou peças para determinado nível, pode ser transferido para outros espaços e contextos de ensino e aprendizagem, mesmo quando não há obrigação de segui-lo, como nas escolas de cursos livres de música ou em aulas particulares de piano. Essa realidade pode estar relacionada à replicação do tipo de programa de ensino pelos quais os professores tiveram durante a sua formação no instrumento (GLASER; FONTERRADA, 2006; TOMANIK, 2011).

Por outro lado, as respostas ainda indicaram que professores direcionam 0 conteúdo musical conforme surgem as situações e necessidades durante as aulas.

A respeito das mudanças que vão ocorrendo no campo do ensino de piano, Bastien (1973), na década de 70, ressaltou que o professor deveria repensar as suas propostas e práticas de ensino, concentrando-se nas necessidades e objetivos dos alunos do tempo presente e não do passado.

Na busca por atender diferentes objetivos, Stateri (2014, p. 74) aponta que os programas dos cursos de instrumento, adotados pelos conservatórios ou pelas escolas de música, têm sido modificados. Tais mudanças ocorrem em decorrência de "reformas oficiais, de aspirações diferentes por parte da clientela e, de objetivos que não têm nada a ver com a formação de profissionais". Acerca disso, o autor relata:

Atualmente, para atender às aspirações dos novos alunos, as escolas de música precisam diversificar ainda mais, oferecendo cursos de música popular, jazz, música sacra, de lazer para a terceira idade, para bebês, etc, [...] e aos interesses de alunos que buscam música erudita sem ter em vista uma carreira de concertista (STATERI, 2014, p. 74). 
Não é uma tarefa fácil desenvolver propostas de ensino que contemplam as necessidades e objetivos de alunos adultos iniciantes e, ao mesmo tempo, oferecer um ambiente favorável às experiências pessoais e musicais.

Nesse sentido, elaborar um programa de ensino de piano direcionado a esse público, cada vez mais crescente, ainda se apresenta como um dos principais desafios, tanto para professores de piano quanto para os diversos contextos e espaços de ensino de música.

\subsubsection{Material didático}

O material didático é um recurso para a prática de ensino e aprendizagem do piano. Quando significativa para o aluno, serve de elemento favorável para a motivação. Com o intuito de conhecer os tipos de materiais didáticos escolhidos pelos professores e utilizados pelos alunos adultos iniciantes entrevistados, esse item retrata os métodos pianísticos, os repertórios e as atividades realizadas nas aulas de piano no contexto de aula individual.

\subsubsection{Métodos pianísticos}

O quadro 6 apresenta os métodos pianísticos indicados pelos alunos entrevistados, na qual um aluno pode indicar mais de um método.

\begin{tabular}{|c|c|}
\hline Métodos pianísticos indicados: & Alunos: \\
\hline Edna-Mae Burnam - A dozen a day & A1, A2, A4 \\
\hline Apostila da Escola & A1, A4 \\
\hline Hanon - O pianista virtuoso - 60 exercícios & A1, A3 \\
\hline Alfred's Basic Piano Library & A4 \\
\hline Alice G. Botelho - Meu piano é divertido Vol. I & A2 \\
\hline Czerny - 60 Pequenos Estudos - Coletânea Vol. 1 & A3 \\
\hline F. Beyer - Escola Preparatória & A1 \\
\hline Leila Fletcher - Piano Course & A5 \\
\hline Mário Mascarenhas - Duas mãozinhas no teclado & A2 \\
\hline Michael Aaron - Curso para piano &
\end{tabular}

Quadro 6 - Relação método pianístico e aluno

Fonte: Elaboração da autora

O quadro 7, por sua vez, apresenta os métodos pianísticos indicados pelos professores entrevistados, onde um professor pode indicar mais de um método. 


\begin{tabular}{|c|c|}
\hline Métodos pianísticos indicados: & Professores: \\
\hline Edna-Mae Burnam - A dozen a day & P1, P2, P3, P4, P6, P8, P9, P11 \\
\hline Alice G. Botelho - Meu piano é divertido Vol. I & P1, P3, P4, P8, P9, P10 \\
\hline Leila Fletcher - Piano Course & P3, P5, P7, P8, P9, P10 \\
\hline James Bastien - Curso de piano para principiantes adultos* & $\mathrm{P} 1, \mathrm{P} 2, \mathrm{P} 7$ \\
\hline John Thompson - Modern course for the piano & $\mathrm{P} 6, \mathrm{P} 11, \mathrm{P} 10$ \\
\hline Hanon - O pianista virtuoso - 60 exercícios & P4, P9 \\
\hline James Bastien - Piano Basics & P5, P10 \\
\hline $\begin{array}{c}\text { Lynn Freeman Olson, Louise Bianchi e Marvin Blickenstaff - } \\
\text { Piano Discoveries }\end{array}$ & $\mathrm{P} 10, \mathrm{P} 11$ \\
\hline Michael Aaron - Piano Course & $\mathrm{P} 4, \mathrm{P} 11$ \\
\hline Alfred - Adult Piano Course* & $\mathrm{P} 1$ \\
\hline Alfred - Basic Piano (criança) & P8 \\
\hline Czerny - 60 Pequenos Estudos - Coletânea Vol. 1 & $\mathrm{P} 4$ \\
\hline $\begin{array}{c}\text { Frances Clark, Louise Goss e Sam Holland - The music Tree: A } \\
\text { Plan for Musical Growth at the Piano }\end{array}$ & P1 \\
\hline George Bull - 25 Pequenos Estudos - Op. 90 - 1ํㅡol. & P7 \\
\hline Hal Leonard - Adult Piano Method $-1^{*}$ & $\mathrm{P} 7$ \\
\hline Leila Fletcher - Piano Course for Adult ${ }^{\star}$ & $\mathrm{P} 1$ \\
\hline Maria de Lourdes J. Gonçalves - Musicalização & P10 \\
\hline Mário Mascarenhas - Duas mãozinhas no teclado & P9 \\
\hline Mário Mascarenhas - O tesouro do pequeno pianista & P9 \\
\hline Melody Bober - Grand Solos for piano - Vol. 1 & P8 \\
\hline Michael Aaron - Piano Course for Adult - Book One* & $\mathrm{P} 1$ \\
\hline Violenta Gainza - Método para piano & P4 \\
\hline
\end{tabular}

Quadro 7 - Relação método pianístico e professor

Fonte: Elaboração da autora

Nota: $O$ sinal asterisco $\left(^{*}\right)$ indica os métodos de piano específicos para o aluno adulto.

A respeito dos métodos impressos utilizados, o professor justifica a sua escolha por não utilizar métodos específicos para o público adulto:

$\mathrm{Na}$ visão de P2, a dificuldade em encontrar um método que lhe agrade e o número reduzido de alunos adultos foram os fatores decisivos. "Para adultos não encontrei um que gosto. Tenho muito pouco, não utilizo muito" (P2).

Já P8 relata que, no início do curso, utiliza métodos para crianças, "o que deixa as aulas divertidas pelos desenhos" e por ser mais fácil de executar:

Não utilizo [métodos de iniciação ao piano para adultos]. Com a experiência, percebi que os métodos para adultos [Leila Fletcher Adult, John Thompson's], não dão bons resultados, são difíceis para iniciantes e 0 aluno, muitas vezes, acaba desistindo. Isso me frustrava bastante porque o aluno adulto chega com muitas expectativas, com vontade de aprender a ler a partitura, ter seus próprios livros (PROFESSORA 8). 
A ausência de métodos voltados para adultos também é observada nas aulas ministradas por P4 que diz: "Eu não uso nenhum método específico para adulto. Eu uso, praticamente, os mesmos para crianças, no nível deles, [...]. Eu não gosto muito de pular etapas dos métodos".

Da mesma forma observa P3: "Não uso método de piano voltado para adultos, somente diferencio nas peças". A professora 7 faz "um mix de métodos", pois não acredita em nenhum método impresso que seja totalmente eficiente.

No sentindo de suprir determinadas lacunas nos métodos, as professoras $6 \mathrm{e}$ 10 criam materiais didáticos. Acerca disso, P6 explica que não possui um método específico para adulto. "Não tenho um método específico que utilizo para adulto. Como eu já dou aulas há muito tempo, há muitas coisas nos métodos que eu acho que se eu criar na hora será muito melhor para o meu aluno". Justificando sua posição, P10 argumenta:

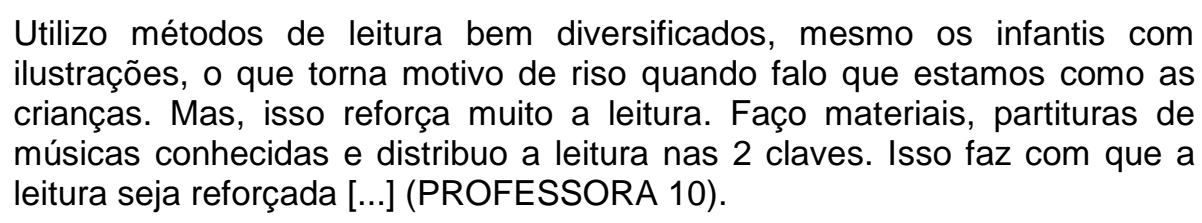

De acordo com as respostas, alguns professores criam materiais didáticos próprios, outros adotam métodos de iniciação (brasileiros e estadunidenses) voltados ao público infantil. A tabela 1 apresenta os métodos infantis com mais indicação entre os alunos e professores entrevistados.

Tabela 1 - Métodos de piano para crianças e suas indicações

\begin{tabular}{cc}
\hline Métodos: & Indicações: \\
\hline A dozen a day, de Edna-Mae Burnam & 11 \\
Piano Course 1, de Leila Fletcher & 7 \\
Meu piano é Divertido (V. I), de Alice G. Botelho & 7 \\
\hline
\end{tabular}

Fonte: Elaboração da autora

A tabela 2 ordena os métodos mais indicados dentre os estrangeiros para 0 aluno adulto. 
Tabela 2 - Métodos de piano para alunos adultos e suas indicações

\begin{tabular}{cc}
\hline Métodos: & Indicações: \\
\hline Curso de piano para principiantes adultos, de James Bastien & 3 \\
Adult Piano Course, de Alfred & 1 \\
Adult Piano Method (Book 1), de Hal Leonard & 1 \\
Piano Course for Adult, de Leila Fletcher & 1 \\
Piano Course for Adult (Book One), de Michael Aaron & 1 \\
\hline
\end{tabular}

Fonte: Elaboração da autora

Diante dos indicativos apontados, o que se constata é que os métodos infantis são os mais utilizados para adultos iniciantes, por parte dos professores e alunos adultos de piano entrevistados. Essa realidade pode estar relacionada a vários fatores, dentre os quais se destacam a segurança do docente em replicar métodos utilizados há muito tempo, a não disposição para pesquisar outras e novas abordagens, o que resulta no não conhecimento de outros tipos de propostas e, ainda, a quase inexistência de material brasileiro de iniciação pianística para adultos iniciantes. Ao adotar um método de iniciação pianística infantil, o professor deve ter em mente que tais materiais apresentam e discorrem o conteúdo musical, levando em conta o desenvolvimento da criança. Na ausência de materiais específicos para o adulto, um dos caminhos é a criação de material didático que poderá ser elaborado de acordo com o desenvolvimento do aluno no instrumento.

Das inúmeras tarefas da prática docente, a escolha por um determinado material didático é apenas um dos aspectos desse processo, pois junto à eleição desses materiais, é preciso atentar para os modos de ensino, uma vez que "a responsabilidade é, também, do professor, pois cabe a ele saber ensinar e passar" (PROFESSORA 1).

\subsubsection{Repertório pianístico}

Quanto ao tipo de repertório realizado nas aulas de piano, as respostas dos alunos entrevistados contemplam diversos deles, como demonstrados no quadro 8 :

\begin{tabular}{|c|c|}
\hline Tipo de Repertório: & Alunos: \\
\hline "Música popular brasileira, samba e música clássica." & A1 \\
\hline "Trechinhos de jazz, música clássica e pop internacional.” & A2 \\
\hline Pop internacional, temas de filmes, música popular brasileira. & A3 \\
\hline Sertanejo, música popular brasileira e gospel. & A4 \\
\hline "Erudita." & A5 \\
\hline
\end{tabular}

Quadro 8 - Repertórios escolhidos pelos alunos adultos de piano

Fonte: Elaboração da autora 
Acerca da escolha e dos tipos de repertório, os professores entrevistados relatam suas práticas no dia a dia. A P1 relata que a escolha do repertório é feita juntamente com o aluno. Além dos métodos impressos, costuma dar peças avulsas que incluem melodias conhecidas do folclore brasileiro e "erudita". Ela utiliza um livro estadunidense intitulado "Favorite Classical", que contém melodias "eruditas conhecidas". Geralmente, faz arranjos simples para que o aluno possa tocar uma determinada música que deseja.

Do mesmo modo, P2 trabalha melodias folclóricas conhecidas e do repertório popular brasileiro. Quando o aluno ainda não sabe ler a partitura, o ajuda a executar por processo de imitação. Quanto à escolha de repertório, além de sugerir algumas peças, os alunos adultos trazem ou indicam outras músicas que queiram tocar.

O repertório utilizado por P3 é trabalhado "de acordo com o gosto musical de cada aluno e para trabalhar técnicas específicas". Inicialmente, vai ao encontro do "mundo musical do aluno". Posteriormente, abre "o leque para outros conhecimentos musicais", diversificando na escolha de compositores e estilos musicais.

De acordo com P4, a escolha de repertório é feita a partir de uma seleção de seu acervo particular de partituras. "Eu tenho muitas partituras. Então, faço uma seleção de quais peças dá para ele [o aluno] tocar, dentro do estrangeiro e nacional". Após apresentar as opções, o aluno escolhe a peça que tocará. Além disso, "há a opção de tocar música a 4 mãos".

Também considerando o gosto musical do aluno, P5 relata que a escolha do repertório é feita de acordo com o gosto do aluno e por ela, "analisando o nível em que o aluno está e adequando o arranjo da música que o aluno quer". Além disso, ela aponta a ausência de "livros de piano com repertório que sejam destinados a esse público, sem temas infantis ou desenhos".

Com muito tempo de atuação na docência, P6 explica que é melhor escrever para os alunos: "eu escrevo no caderno deles e não registro para mim. Depois eu perco [essas anotações]". Acrescenta, ainda, que não fica presa aos métodos tradicionais e nem nos estadunidenses, pois nem sempre trazem uma melodia conhecida. Ela considera que o professor tem que "ser bem aberto" para trabalhar diferentes tipos de repertório.

Com uma abordagem diversificada, P7 indica que trabalha com "um pouco de tudo: melodias folclóricas, brasileiras e eruditas". Quanto à escolha do repertório, ela 
é feita de acordo com "o universo do aluno e visando o aprendizado de determinados assuntos".

Para P8, o repertório é feito com "músicas de preferência do aluno", apresentando "peças dos livros, arranjos de músicas populares e novos arranjos que sejam solicitados pelo discente".

Considerando o gosto do aluno, P9 relata que o repertório é feito de acordo com "a vontade e com o gosto da pessoa e com aquilo que é necessário" para aprender a tocar. O repertório contempla "temas folclóricos, temas conhecidos e músicas facilitadas".

Ao trabalhar com diversas músicas fáceis e conhecidas do repertório de música brasileira e não brasileira, P10 descreve que, ao escolher tal tipo de música, intercala o que considera "bom" para a aprendizagem do aluno, com o repertório que os alunos gostam. Além disso, em suas palavras, "se não tenho alguma música, procuro fazer uma partitura facilitada para que eles possam tocar".

Já P11 aponta que a seleção é feita entre o professor e o aluno. A docente considera que o aluno iniciante "não pode tocar músicas muito difíceis. Ele precisa tocar no nível dele para se sentir feliz e realizado". Ou seja, o professor "precisa dar aquilo que o aluno irá tocar, não tão fácil, mas que seja a medida dele, aquilo que ele conseguir fazer até aquele momento. Então, ele se sentirá realizado e terá facilidade para tocar".

De acordo com as respostas dos entrevistados, os tipos de repertórios mais trabalhados nas aulas de piano para adultos são a "música clássica" ou "erudita" (os entrevistados utilizaram ambas as classificações para indicar a música erudita europeia), a folclórica e música popular brasileira. A escolha do repertório é realizada juntamente com o aluno, que pode ocorrer em duas situações: (1) o aluno traz ou sugestiona alguma peça que queira tocar e, em segunda, (2) o professor leva as opções e o aluno escolhe uma das peças apresentadas pelo docente.

Apesar do repertório pianístico ser extenso, nem sempre estão acessíveis peças em níveis de execução para o aluno adulto iniciante. Em relação ao repertório brasileiro, a quantidade de peças voltadas para esse perfil de aluno é quase inexistente. Em sua maioria, o repertório pianístico no nível elementar é voltado para crianças, com temas e títulos infantis.

No sentido de suprir essa lacuna, Campos (2014) compôs "13 pequenas peças brasileiras: coletânea para o iniciante de piano". De acordo com a autora, 
essas composições foram escritas para seus alunos iniciantes e com a "única intenção de usar a riqueza da música brasileira para motivá-los”. Além disso, oferece ritmos que já estão nos seus "ouvidos" e dá aos alunos ocasião para desenvolver a leitura de alguns padrões rítmicos que fazem parte das raízes brasileiras. Alguns dos títulos da coletânea são: "Baião Mulato", "Sertaneja", "Nova Bossa", "Cantoria nas Teclas", "Seresta”, "Rock Brasileiro”, dentre outros (CAMPOS, 2014, p. 7-8).

A criação de repertório com obras em níveis de execução para iniciantes adultos é uma das possibilidades de expansão. Outra possibilidade é conhecer "as riquezas melódicas de culturas não ocidentais e músicas de tradição oral que pode se transformar através da escrita e conhecer uma segunda via dentro de um contexto cultural" (CASTRO, 2013, p. 50). Junto a essas possibilidades, estão os arranjos musicais que proporcionam diversidade no repertório musical para piano, especialmente para os alunos iniciantes. Através de arranjos, os alunos poderão tocar uma música que conhece e aprecia, sendo um fator motivador para o aluno adulto iniciante. Além disso, as práticas de tirar músicas "de ouvido" e criar e compor são atividades que podem ser incorporadas ao repertório musical.

\subsubsection{Atividades de criação}

"A música criativa atende a qualquer idade, pois $\mathrm{o}$ ato de explorar criativamente segue a regra fundamental de se fazer música ouvindo" (PAYNTER; ASTON, 1985).

Quanto às atividades de criação, os alunos entrevistados relatam que não realizam esse tipo de atividade em suas aulas de piano.

Para A3, o pouco tempo de aprendizado ainda é um fator que limita a execução dessas atividades. "Sou iniciante, com apenas dois meses de aprendizado". Segundo A2 e A5, antes de estudarem piano, já tocavam "de ouvido". E A2 ressalta que tem facilidade em tirar música "de ouvido", mas com o estudo do piano, essa prática foi deixada de lado. Sobre isso, explica:

Eu "bato" em uma tecla e vem a música inteira em minha cabeça. Um dia na aula, eu toquei um pequeno trecho e a professora disse: é o trecho da Carmem de Bizet. Mas, o meu sonho era ler partitura e, por isso, eu tento não tirar mais nada de ouvido. Eu quero fazer o certo para eu aprender a fazer a nota certa (ALUNA 2, grifo nosso).

Na visão de A2, fazer o "certo" no piano é saber ler a partitura. A valorização de um aspecto (a leitura da partitra) em detrimento de outro (tocar de ouvido) parece 
se relacionar à experiência da aluna em "tirar" música "de ouvido" sem a presença do professor, como consta seu relato, no item "Trajetória Musical". No entanto, Campos (2000) defende que as práticas "tocar de ouvido" e leitura da partitura são relevantes e devem coexistir nos contextos de ensino e aprendizagem musical.

Propondo uma prática musical que não delimita fronteiras entre os aspectos sensorial (o ouvido) e racional (a leitura), Campos (2000, p. 157) ressalta que tais aspectos são importantes para a prática no piano, pois "se essas duas maneiras de praticar música forem introduzidas sob o sentido de complementariedade entre si, sendo, assim, valorizadas pelo professor, o aluno obterá naturalidade e liberdade".

Sobre as atividades de criação, as respostas dos professores entrevistados sugerem que essas atividades fazem parte do processo de ensino:

\footnotetext{
"Faço os alunos criarem" (PROFESSORA1);

"Trabalho muito pouco. O que eu ensino mais é leitura" (PROFESSOR 2);

"Proponho improvisação e composição escrita" (PROFESSORA 5);

"Dentro da escala, eu peço para ele [o aluno] criar outras combinações sem ser a sequência" (PROFESSORA 6);

"Sim, sempre de improvisação com teclas pretas, brancas, determinadas notas e figuras dadas" (PROFESSORA 7).
}

Para P3, as atividades de criação acontecem na medida em que ela propõe exercícios para que os alunos possam criar, dentro de uma harmonia préestabelecida, ou a "criação total do aluno, onde ele cria um tema, coloca a harmonia e escreve sua própria partitura". De acordo com P8, as atividades de criação ocorrem nas "variações das peças, introduzindo acordes, leitura de cifras, mudança de mão para as claves, pequenos improvisos em determinados compassos, dentre outros". Segundo P11:

Já fiz isso. Às vezes, coloco um acompanhamento, com dois ou três acordes, e o aluno cria alguma melodia na mão direita [...]. Acho muito importante porque $o$ aluno se sente muito feliz, ainda mais se ele fizer uma coisa simples que você cria em cima. Ele se sente um compositor, mais do que o "Beethoven" (PROFESSORA 11).

Já P4 relata: "peço para o aluno acrescentar aspectos relacionados à dinâmica, fraseado [...]. Eles criam ou fazem um acabamento das peças que estão tocando". 
Outro aspecto apontado é a dificuldade, por parte do adulto, diante das atividades de improvisar e criar.

Para P9 e P10, as crianças são mais abertas para esse tipo de atividade. Por essa razão, quase não trabalham essa prática com adultos. A respeito disso, P9 justifica:

Com o adulto eu tento fazer, mas muitos estão travados em aprender aquilo [...]. Ele tem dificuldade de criação e acha que não está bonito. Ele não dá abertura para isso. Mas, eu trabalho, não com todos, mas com aquele que dá abertura, com aquele que tem vontade.

A questão levantada pelas professoras 9 e 10 pode estar associada ao fato de que o adulto tem sua compreensão do que seria uma "obra musical" a partir de suas referências e concepções musicais. Esse entendimento pode levá-lo a considerar que não está preparado para criar ou compor, como apresenta a resposta do aluno 3.

Outro aspecto a ser considerado é que o adulto, geralmente, prefere não se expor ou participar de experiências que possam deixá-lo inseguro. Contudo, o modo como o professor apresenta e orienta esse processo é relevante, pois através de atividades criativas no piano o aluno poderá perceber o seu potencial criativo e compreender os diversos aspectos da prática musical.

Verifica-se, ainda, que os professores entrevistados trabalham com diferentes tipos de atividades criativas em suas aulas de piano. Por outro lado, as respostas dos alunos entrevistados, dos quais três são alunos de professores participantes dessa pesquisa, demonstram que a leitura e a interpretação da partitura são os aspectos mais trabalhados em suas aulas. Alguns, ainda, relatam a experiência com a prática de tocar "de ouvido", que foi deixada de lado ao iniciar o estudo do instrumento com o professor.

Apesar dos adultos, em geral, serem mais resistentes a uma nova aprendizagem, o envolvimento criativo com a música poderá ser alargado através de incentivo por parte do professor. Para isso, é necessário que professor e aluno estejam dispostos a incorporarem essas atividades em suas experiências de ensino e de aprendizagem de piano. 


\subsubsection{Modos de ensino}

Aquele conceito em que o professor é detentor de todo o conhecimento já caiu em desuso. Hoje, o novo paradigma educacional é considerar o aluno como parte constante da criação do seu conhecimento. Ambos constroem juntos. Não é somente o professor que está ali ensinando. É a criação de ambos os lados (PROFESSOR 2).

A respeito de como o seu professor de piano apresenta o conteúdo musical, os alunos participantes relatam que:

"O conteúdo é passado de forma gradativa e seguindo o meu desenvolvimento diante de atividades passadas" (ALUNA 1);

Ela [a professora] explica e fala sobre o que iremos trabalhar para eu entender. Ela também toca, algumas vezes, para eu ouvir, principalmente na questão de tempo e quando não estou fazendo corretamente. Eu sinto um pouco de dificuldade no tempo e ela toca para mim. E como o meu "ouvido" funciona bem, eu escuto e toco (ALUNA 2);

"A cada aula é proposto um estudo de um exercício. Na aula seguinte, todos os exercícios anteriores são revisados, com acréscimo daquele proposto na aula anterior" (ALUNO 3);

"A aula é dividida em partes, pois nem sempre fazemos os exercícios, os métodos e repertórios em todas as aulas. Às vezes dividimos a aula só em técnica, ou só livro de estudo, ou mesclamos repertório e técnica e assim por diante..." (ALUNA 4);

"A professora acompanha, tocando junto, com exercícios a 4 mãos. Ela explica o exercício, falando ou tocando" (ALUNO 5).

Por outro lado, as respostas dos professores entrevistados indicam como se

dão as suas ações docentes em aulas individuais para adultos iniciantes.

Além de trabalhar o aspecto teórico, P1 trabalha a "alfabetização musical" na iniciação ao piano. Acerca disso, descreve:

A gente tem o caderno de teoria, onde eu passo para o aluno toda a parte teórica desde o início. Na prática, eu trabalho com o método Divertimentos, de Laura Longo, por frases, com pentacordes, ou mesmo criando melodias para eles repetirem. Gosto de fazer isso para que eles possam tocar alguma coisinha, para terem o conhecimento de teclas pretas e brancas e tocarem nelas (PROFESSORA 1).

Além da prática no piano, P5 utiliza um caderno de música para explicar os conceitos teóricos musicais, "como é realizado com as crianças, mas com linguagem mais adulta, buscando um repertório mais folclórico ou que não seja tão infantil”. 
O aspecto da "linguagem mais adulta" também é apontado por P2: "[...] para o adulto, você fala em uma linguagem mais específica. Você já diz "essas são as 7 notas musicais".

Segundo P3, os modos de ensino para adulto estão na "forma de falar, na colocação das palavras e no tipo de repertório". No entanto, faz uso do mesmo livrométodo de piano para crianças e adultos, pois considera que "o adulto é uma criança no início do seu estudo". Além da leitura da partitura, a professora trabalha "a percepção auditiva do aluno".

As estratégias de ensino de P4 dependem muito de cada aluno. Sobre seus modos de ensinar para adultos, ela explica:

Começo pela pauta e pelas claves, mas não conto estorinhas como faço com as crianças. Em duas aulas eles já sabem a leitura das primeiras notas nas linhas e espaços, a função das claves, os valores das figuras, os nomes e pausas. Sabendo isso, ele vai ler qualquer partitura que tenha as claves de Sol e Fá.

Através do processo de imitação e, posteriormente, a leitura de partitura, P6 gosta de tocar a 4 mãos com os alunos e trabalhar melodias que os mesmos gostariam de tocar. Ela ressalta, ainda, que as "coisas vão mudando, passando rápido", refletindo na questão de que os alunos também "esperam uma resposta rápida", sendo necessária a atenção do professor para o perfil de alunos que anseiam pela prática no instrumento.

Nesse ponto, P7 considera a dificuldade do aluno adulto em colocar em prática aquilo que entende. A docente aborda "conceitos contextualizados à realidade de cada um, mas com vivência corporal de pulso e ritmo". Embora perceba "que enquanto os adultos entendem rapidamente, é muito mais difícil para eles colocarem em prática".

Quanto à prática de ensino de P8, essa inclui a apresentação de um mesmo conteúdo, mas de maneiras diferentes. Além de utilizar métodos infantis, considerados mais fáceis de serem executados, a docente não percebe muita diferença entre alunos adultos e de outras faixas etárias, mas "sim de indivíduos". Desse modo, ela apresenta o mesmo conteúdo, mas de formas diferentes.

Sem livros no início, P9 trabalha "uma leitura bem básica, passando no caderno alguma coisa". Primeiramente, ela trabalha o conhecimento do instrumento. Em seguida, a "questão motora, dos dedos e de postura do corpo". Ainda no 
primeiro mês, trabalha "acordes, arpejos e repertório, tudo em folhas soltas". Após isso, "introduz os livros para os iniciantes", juntamente com as atividades teóricas realizadas no caderno de música.

Na condução das aulas, P10 sempre toca junto, aplica exercícios de leitura e, "dependendo da dificuldade" do aluno, cria acompanhamentos, a fim de tornar a aula mais interessante. A professora prefere utilizar o autoacompanhamento do teclado, com ritmos, como bolero, samba e rock lento, fazendo uso de métodos de leitura bem diversificados, mesmo os infantis com ilustrações. Ela cria materiais, faz arranjos de músicas conhecidas e distribui a leitura nas claves de Sol e de Fá. Segundo ela, "isso faz com que a leitura seja reforçada".

$\mathrm{Na}$ concepção de P11, mesmo utilizando, simultaneamente, materiais didáticos infantis e adultos, "você fala no nível para adultos", pois "a linguagem precisa ser mais no nível deles". Ela ressalta que o aluno tem expectativa de tocar imediatamente, colocando a seguinte questão logo na primeira aula: Será que eu vou demorar muito pra tocar? Posto isso, "a parte teórica" é ensinada na primeira aula, já introduzindo o aluno para "a parte prática", para tocar a quatro mãos no piano. Para P11, "é uma maneira do aluno já tocar sentindo-se empolgado com o estudo do piano". Na iniciação, a docente explica "o som com os símbolos que ainda não são as notas musicais", sempre tocando, até chegar à leitura das notas da partitura.

O que mais se destaca nas respostas dos professores entrevistados é que o ensino para adultos deve ser em "linguagem mais adulta". No entanto, alguns modos de ensino para eles parecem partir das experiências dos próprios professores com crianças iniciantes no instrumento. Adultos são mais do que crianças crescidas. Constantemente, eles apresentam aspectos relevantes para a sua aprendizagem, que podem servir de direcionamento para as ações docentes.

A ideia de "falar com o adulto de forma adulta" envolve compreender as especificidades da realidade desse público, considerando a sua relação com a aprendizagem, suas experiências pessoais e musicais através das várias ações da prática docente, como a elaboração das propostas de ensino, da aplicação prática dos conceitos teóricos musicais, a escolha de materiais didáticos, dentre outros. 


\subsection{Experiências de adultos com a aprendizagem pianística}

A aprendizagem do adulto deve ser direcionada para o seu objetivo e deve ser construída em cima de desafios (MEDEIROS, 1998, p. 85).

Após os alunos apresentarem seus motivos e as razões pelas quais desejam estudar piano, eles serão orientados pelos modos de ensinar do professor. Nesse processo, experiências ocorrem, conhecimentos são adquiridos e caminhos percorridos, como apontam as respostas dos participantes desse estudo.

O quadro 9 relaciona as respostas dos alunos adultos entrevistados, em aspectos favoráveis e não favoráveis ao processo de aprendizagem do piano na fase adulta:

\begin{tabular}{|c|c|c|}
\hline \multirow{2}{*}{ Aluno: } & \multicolumn{2}{|c|}{ Experiências com a aprendizagem pianística } \\
\cline { 2 - 3 } & Elementos favoráveis: & Elementos não favoráveis: \\
\hline A1 & Compreensão dos conceitos teóricos. & $\begin{array}{c}\text { Rítmica, habilidade motora e } \\
\text { concentração ao estudo. }\end{array}$ \\
\hline A3 & $\begin{array}{c}\text { Gosto pela prática de tocar. } \\
\text { organização do tempo de estudo e a } \\
\text { vontade de aprender. }\end{array}$ & $\begin{array}{c}\text { Ânimo para exercitar e a busca por } \\
\text { resultado. }\end{array}$ \\
\hline A4 & Compreensão da teoria musical. & $\begin{array}{c}\text { Repertório apropriado e tempo para } \\
\text { estudar. }\end{array}$ \\
\hline A5 & Muita vontade de estudar. & $\begin{array}{c}\text { Tempo dedicado ao estudo e a } \\
\text { leitura da partitura. }\end{array}$ \\
\hline
\end{tabular}

Quadro 9 - Elementos favoráveis e não favoráveis na aprendizagem do piano por alunos adultos

Fonte: Elaboração da autora

Nesse contexto, A5 acrescenta que a sua dificuldade em ler a partitura está relacionada, principalmente, com sua prática anterior: a de "tocar de ouvido". Segundo ele, "os vícios atrapalham muito porque eu sei tocar do meu jeito. E eu tocava somente com a mão direita. Agora, é mais díficil com a mão esquerda. Ler a partitura é um exercício complicado".

Alguns dos aspectos apresentados pelos alunos adultos são recorrentes e outros são indicados nas respostas dos professores.

Nesse sentido, P1 considera que os adultos "são mais tensos para a execução pianística e têm dificuldade para memorizar". Para ajudar na memorização, a docente trabalha com frases musicais, utilizando, tanto para crianças quanto para adultos, o método Divertimentos, de Laura Long. 
Já P2 acredita que tais aspectos dependem da motivação de cada um. Para esse professor, os problemas emocionais podem prejudicar a forma de tocar 0 instrumento, pois se um aluno é "muito travado", seu desempenho não será o mesmo. A impaciência também é apontada pelo professor. "O adulto começa o curso e já quer sair tocando. Ele não tem aquela paciência de tocar uma musica mais simples, de começar lá da iniciação. Às vezes, ele acaba se frustrando e desistindo". Além disso, P2 ressalta que o adulto tem pouco tempo para estudar fora do período das aulas.

Essa característica é mencionada por P3, que relata que os adultos "nem sempre têm paciência por serem um pouco imediatistas".

Segundo P4, "com o adulto, você vai mais direto ao ponto, sem muito rodeio, pois ele já tem uma capacidade de entendimento mais apurada e madura que a da criança, principalmente as menores. Ele [o adulto] tem dificuldade de ler a partitura e aplicá-la com agilidade". Dentre as facilidades indicadas estão a responsabilidade e a vontade de tocar. Por isso, estudam mais e são mais autênticos por dizer, na aula, que "essa semana estudou muito pouco e, portanto, a aula não irá fluir". A dificuldade em ler a partitura também é indicada por P10:

[...] na questão da leitura, fica quase a mesma coisa: procuro reforçar muito a leitura musical com crianças e adultos, utilizando métodos bem variados e em grande quantidade. Acho que dá um ótimo resultado em ambos os casos.

Ao traçar um comparativo entre adultos e crianças, P5 considera que ambos possuem aspectos diferentes. Os adultos são "muito resistentes e questionadores em comparação às crianças". Às facilidades do aluno adulto estão relacionadas ao agendamento e pagamento das aulas, à decisão e motivação. "A criança pode ir por vontade dos pais, os adultos não".

Para $\mathrm{P} 10$, os adultos demoram mais pra adquirir as habilidades necessárias para a prática do piano. "No geral, eles têm menos facilidades, mas existem sempre as exceções".

Descrevendo sobre as dificuldades encontradas nos alunos adultos, P6 coloca a percepção rítmica e a coordenação motora como duas delas. No sentido de auxiliar a superar essas dificuldades, além de criar exercícios fora do piano, com as mãos direita e esquerda e com dedos separados, ela trabalha a imitação. "O aluno 
adulto não tem a leitura [da partitura] ainda, mas, geralmente, ele consegue realizar a atividade se me ver tocar. Então, eu trabalho bastante com a imitação".

De acordo com P9, a compreensão teórica do adulto é um aspecto favorável na aprendizagem do piano. No entanto, as principais dificuldades encontradas por ele são os aspectos motores e o tempo de estudo. Na visão da docente,

\begin{abstract}
[...] a habilidade motora é difícil, mas a compreensão teórica é maior. Eles têm essa dificuldade "do executar". Às vezes, eles se cobram muito, pensam muito para realizar. Para a criança, basta você explicar que ela vai e faz ali. $\mathrm{O}$ adulto fica querendo ter o entendimento para, depois, executar a ação. Então, ele é um pouco mais travado que a criança. Na observação de fazer o perfeito, muitas vezes, não se deixa abrir a mente. Acho que o pior para o adulto é que ele tem a compreensão da teoria, entende as coisas, mas não tem tempo para estudar [...] (PROFESSOR 9).
\end{abstract}

Segundo P7, o aluno adulto de piano tem dificuldades relacionadas à tensão física. Já a linguagem pode ser mais direta e objetiva, "bem como os conceitos podem ser apresentados de maneira mais racional".

Para P11, os adultos entendem com muita rapidez "a parte teórica musical", mas encontra dificuldades na "parte prática", como a agilidade com as mãos e a coordenação motora. Esse docente considera que "eles [os adultos] não possuem a coordenação de ler e tocar rapidinho ao mesmo tempo. Eles têm muita dificuldade".

Apesar de não especificar quais as dificuldades desses alunos adultos, P8 considera que eles possuem "dificuldades muito semelhantes [comparado aos alunos de outras faixas etárias], superadas pela prática e estímulos do professor". Quanto aos elementos favoráveis, ela considera que os adultos que já estão aposentados "têm mais tempo para os estudos e se esforçam bastante".

As respostas dos entrevistados apresentam, como aspecto mais favorável da aprendizagem de piano na fase adulta, a compreensão teórica dos conceitos musicais, seguida pela motivação, relacionada, principalmente, à vontade de tocar piano. Dos elementos não favoráveis, ou considerados difíceis, os mais destacados são a falta de paciência e a disponibilidade de tempo para estudar, a leitura da partitura e a coordenação motora. A leitura musical é uma das habilidades necessárias à execução pianística, mas pode se tornar um processo difícil, pois é preciso compreender as informações que estão na partitura. Ela ainda pode ser uma 
dificuldade intensificada para os alunos que já tocavam "de ouvido" antes de iniciar o estudo do piano, como indicam as respostas de $\mathrm{A} 2$ e $\mathrm{A} 5^{17}$.

Segundo Campos (2000, p. 157), "ler música pode ser uma prisão para os que aprenderam a fazê-la apenas de ouvido". Da mesma forma, o processo inverso também pode ser díficil, pois "tocar de ouvido pode parecer impossível para quem só tocou piano lendo". É necessário trabalhar a leitura da partitura atento ao som produzido. Embora essa postura pareça ser tão óbvia no estudo de um instrumento, na prática, esse processo parece estar mais vinculado à notação musical e à preocupação de tocar na tecla correspondente do que à escuta do som.

Quanto às respostas "pouca paciência" e "falta de tempo para estudar", mencionadas pelos participantes, as mesmas podem ser reflexos do estilo de vida agitado e corrido que os adultos levam no dia a dia.

Diante da realidade do presente século, ou seja, dos resultados dos avanços das tecnologias da informação e da comunicação, das interações efetuadas de modo tão rápido com os usuários e da correria e agitação dos centros urbanos que impactam a vida pessoal e profissional do adulto, a paciência para aprender a tocar piano e a disponibilidade e o ânimo para estudar fora dos horários das aulas se tornam em elementos a serem superados por esse público que busca por esse conhecimento.

Nesse percurso de prática musical amadora, não apenas a compreensão teórica do adulto se apresenta como o aspecto mais vantajoso e relevante, indicado pelos participantes desse estudo, mas experiências vão ocorrendo e a relação "sentir e fazer música" se torna essencial, pois "o prazer de sentir a música [...] é indescrítivel" (ALUNO 3, grifo nosso).

Assim:

Quando você é criança, você faz porque seu pai ou sua mãe quer. Nessa fase, a gente faz porque gosta, gosta da música, gosta de sentir. Fazer música é uma sensação que só quem faz sente. É muito bom e acho que esse é o ponto positivo (ALUNA 2, grifo nosso).

17 Ver as respostas de A2 e A5 no item 3.3.2.3 Atividades de Criação. 


\section{CONSIDERAÇÕES FINAIS}

Empenhemo-nos em atender às necessidades emergentes da sociedade através de visões ampliadas da educação que reconhecem e cultivam o desenvolvimento musical ao longo da vida (MYERS, 1992, p. 5).

A realidade dos alunos adultos iniciantes que procuram pelo estudo do piano apresenta desafios para o aluno, para a prática docente e para os diversos contextos e espaços de ensino de música que atuam com esse público específico.

Os modos de ensino do professor de piano, evidentemente, são frutos de sua formação musical e instrumental, provenientes dos diversos cursos na área e de suas experiências com a docência ao longo de sua trajetória musical.

Os professores entrevistados neste estudo não trabalham apenas com alunos adultos, mas com alunos de outras faixas etárias e em diversos contextos e espaços formais e não formais de ensino de música. Os locais de atuação mais indicados por esses professores foram, primeiramente, a escola de música, seguido pela casa do professor. Depois, vieram o conservatório de música, a educação básica e o ensino superior, este último local com apenas uma indicação. Tais constatações apontam para a necessidade de elaboração de propostas de ensino de música, considerando os vários aspectos de aprendizagem em diferentes fases da vida.

$\mathrm{Na}$ fase adulta, os adultos apresentam aspectos característicos de aprendizagem. O adulto, geralmente, é firme em suas ideias e concepções e possui grande capacidade de abstração e racionalização. Além de objetivos e interesses pessoais, ele pode indicar caminhos significativos de aprendizagem para si mesmo. Nesse processo, destaca-se a importância do professor que atua para esses alunos. Através dos relatos do aluno adulto acerca de sua relação com a aprendizagem, o professor poderá refletir sobre as suas ações em sala de aula.

O desejo de aprender a tocar piano e as experiências pessoais e musicais adquiridas ao longo da trajetória de vida de cada um são elementos favoráveis à decisão do adulto em ter aulas de piano. Ao procurar por aulas, eles estão motivados e apresentam diversas razões para iniciar o estudo do instrumento. As respostas dos cinco alunos adultos entrevistados neste trabalho indicam que essa decisão diz respeito não apenas à realização de um desejo antigo, mas de experiência pessoal, de prazer e satisfação, dentre outros. Constatou-se ainda, por parte desse público, o desejo de interagir com seus ambientes através da prática 
musical. O que se apresenta é o fazer musical como um elemento motivacional significativo para esses alunos. Assim, adultos buscam realizar atividades musicais porque se sentem bem quando as realizam. Aqui, questões relacionadas ao significado da música surgem e se tornam relevantes para serem discutidas em futuros estudos, uma vez que esse não foi objetivo do presente trabalho.

A procura de aulas de piano por parte de adultos, por outro lado, abre um caminho para a entrada de outras questões passíveis de serem analisadas. Dentre essas questões estão os programas de ensino de piano oferecidos para esse público, na atualidade, bem como os tipos de materiais didáticos utilizados pelos docentes em atividades realizadas nas aulas.

Nesse estudo, a maioria das respostas dos professores e dos alunos adultos indica que a prática de ensino de piano para esse segundo público, mesmo em cursos livres de música, em aulas particulares ou na casa do professor, é quase sempre orientada pelo modelo de ensino utilizado pelos conservatórios de música para o estudo progressivo do piano.

De acordo com as respostas obtidas, o programa de ensino abarca estudos, técnicas, recreativos e repertórios. A escolha do repertório, geralmente, contempla as preferências musicais do aluno adulto. Nesse contexto, verifica-se, ainda, a escassez de materiais didáticos nacionais de iniciação ao piano para o aluno adulto e a necessidade de publicações específicas. $\mathrm{Na}$ falta de materiais didáticos para adultos, os professores de piano recorrem aos métodos impressos voltados para a fase infantil.

Muitos dos materiais para adultos iniciantes estão disponíveis em publicações estrangeiras e podem abarcar a leitura e a interpretação de partitura, teoria, técnica, repertório e atividades de criação e improvisação no piano. Alguns desses materiais foram analisados neste trabalho, como o Adult Piano Course (1943), de John Thompson, The older beginner piano course (1977), de James Bastien, Adult Piano Adventures (2009), de Nancy e Randall Faber, e o Upper Hands - A Method for Adults 50+ (2012), de Gaili Schoen. Tais materiais são importantes fontes de abordagens de conteúdos musicais para quem atua no ensino de piano para adultos iniciantes.

Junto à escolha e à utilização dos materiais didáticos (métodos e repertórios) para adultos iniciantes de piano, outro aspecto evidenciado nesse estudo possui 
relação com a presença de atividades não ligadas diretamente à leitura da partitura, como criar, improvisar ou tocar "de ouvido" no instrumento.

As respostas dos professores indicam que eles propõem atividades criativas para seus alunos adultos. Em contrapartida, os alunos entrevistados relatam a ausência dessa prática em suas aulas. A dificuldade de trabalhar com atividades de improvisação e criação em aulas de piano para alunos iniciantes é destacada, resultando quase sempre na concepção de falta de mestria por parte deles, ou ainda, a ideia de que essa prática é restrita aos profissionais da área. Esse tipo de atividade, por sua vez, pode se apresentar como uma tarefa difícil para quem está iniciando. No entanto, as experiências do docente com essa prática e o modo criativo de como as atividades serão abordadas nas aulas poderão levar o aluno adulto a vivenciar momentos tão inerentes ao fazer musical.

A presença de atividades de criação, improvisação ou tocar alguma música "de ouvido" nas aulas de piano, para esse perfil de aluno, pode ocorrer à medida que as propostas de ensino, dos professores e dos espaços de ensino de música, reconheçam a importância dessa prática nos processos de ensino e aprendizagem do piano.

A respeito dos modos de ensino dos professores de piano para o aluno adulto, as respostas dos professores entrevistados indicam que o ensino para adultos deve partir de uma "linguagem adulta". Contudo, algumas ações ainda parecem estar vinculadas a uma prática docente voltada para a iniciação de crianças no instrumento. Nesse contexto, torna-se relevante que as propostas de ensino de piano para adultos sejam repensadas. Ministrar aulas para esse público implica em compreender as suas razões para com o estudo do piano e em apresentar os conteúdos próprios da aprendizagem e da prática desse instrumento, considerando os modos de apreensão de conhecimentos, experiências e particularidades de quem se encontra nesse momento da vida.

Diante do processo de aprendizagem pianística, dificuldades relacionadas à coordenação motora, à leitura da partitura, à memorização, aos materiais didáticos utilizados em aula e à falta de tempo para estudar são alguns dos desafios a serem vencidos por eles. Contudo, as motivações, a vontade de aprender e as experiências significativas com o fazer musical, podem se transformar em elementos favoráveis à aprendizagem do piano nessa fase da vida. Assim, fazer música se torna essencial para esses alunos. 
A prática musical de adultos iniciantes se caracteriza como uma prática amadora significativa, visto que, através dela, as pessoas estão fazendo música. Além da perspectiva de aprendizagem por toda a vida, essa prática contempla experiências pessoais, musicais e sociais. Logo, verifica-se, a existência da interação entre os elementos internos e externos, tão atuantes nos processos de ensino e aprendizagem de música, caracterizada aqui pelos solilóquios e diálogos dos participantes.

É notória, portanto, a crescente procura de adultos por aulas de piano. Esta pesquisa buscou compreender como ocorre o ensino de música através do piano para adultos iniciantes em aulas particulares, em escolas livres de música e em conservatórios, na cidade de Ribeirão Preto. Apesar das constatações observadas, se faz necessário que outros trabalhos surjam e busquem refletir sobre as propostas deste ensino e sobre as particularidades deste público.

É certo que muitas questões ainda precisam ser estudadas sobre essa temática, como a implementação e o oferecimento de cursos de piano para adultos iniciantes, a prática de tocar "de ouvido", de improvisação e suas implicações na relação com a música grafada, a prática musical e a qualidade de vida de adultos, dentre tantos outros assuntos pertinentes ao tema. Tais reflexões são importantes para a área que trata dos processos de ensino e aprendizagem de música e do ensino do piano para alunos adultos. 


\section{REFERÊNCIAS}

AGAY, D. The art of teaching piano. USA: Yorktown Music Press, 2004.

ALBUQUERQUE, A. F. A. de. Aprendizagem musical a partir da motivação: um estudo de caso com cinco alunos adultos de piano da cidade do Recife. 2011.

Dissertação (Mestrado em Música) - Universidade Federal da Paraíba, Recife, 2011.

ALENCAR, E. M. L. S. Criatividade. Brasília: UnB, 1993.

ARAÚJO, R. C. Motivação para prática e aprendizagem da música. In: ARAÚJO, R. C.; RAMOS, D. (Org.). Estudos sobre motivação e emoção em cognição musical. Curitiba: Editora UFPR, 2015. cap. 2, p. 45-58.

BASTIEN, J. How to teach piano successfully. USA: General Words and Music Co., 1973.

. The older beginner piano course. USA: A. Kjos Music Company, 1977.

BEE, H. L; MITCHELL, S. K. A pessoa em desenvolvimento. São Paulo: Harper \& Row do Brasil, 1984.

BOZZETO, A. Ensino particular de música: práticas e trajetórias de professores de piano. Porto Alegre: UFRGS/FUNDARTE, 2004.

BRASIL. Lei no 10.741 , de $1^{\circ}$ de outubro de 2003. Dispõe sobre o Estatuto do Idoso. Disponível em: <http://www.planalto.gov.br/ccivil_03/leis/2003/l10.741.htm>. Acesso em: 30 ago. 2014.

. Lei oㅜ 12.852, de 5 de agosto de 2013. Institui o Estatuto da Juventude e dispõe sobre os direitos dos jovens, os princípios e diretrizes das políticas públicas de juventude e o Sistema Nacional de Juventude - SINAJUVE. Disponível em: <http://www.planalto.gov.br/ccivil_03/_Ato2011-2014/2013/Lei/L12852.htm>. Acesso em: 30 ago. 2014.

BRITO, A. X.; LEONARDOS, A. C. A identidade das pesquisas qualitativas: construção de um quadro analítico. Cadernos de Pesquisa, n. 113, p. 7-38, jul., 2001.

BUCHER, $\mathrm{H}$. Toque piano hoje ...e sempre: curso de piano para adulto - Volume 1. Vitória: Gráfica A1, 2009.

CAMP, S. L. The status of the private piano teacher in music education in select Southern central states. 1975. Ph. D. Dissertation (Music Education) - Indiana University, Indiana, 1975.

CAMPOS, M. C. A educação musical e o novo paradigma. Rio de Janeiro: Enelivros, 2000. 
13 pequenas peças brasileiras: coletânea para o iniciante de piano.

Brasília: Verbis Editora, 2014.

CASTRO, M. C. Educação-campo maior de aplicação da pesquisa em música. In: SIMPÓSIO DE ESTÉTICA E FILOSOFIA DA MÚSICA, 1., 2013, Porto Alegre. Anais... Porto Alegre: UFRGS, 2013. p. 44-53. Disponível em: <http://www.ufrgs.br/esteticaefilosofiadamusica/AnaisSEFiM_2013UFRGS.pdf>. Acesso em: 14 maio 2014.

CHIZZOTTI, A. Pesquisa em Ciências Humanas e Sociais. 9. ed. São Paulo: Cortez, 2008.

COOPER, T. L. Adults' perceptions of piano study: achievements and experiences. Journal of Research in Music Education, v. 49, n. 2, p. 156-168, 2001. Disponível em: <http://jrm.sagepub.com.ez67.periodicos.capes.gov.br/content/49/2/156>. Acesso em: 12 maio 2015.

COSTA, J. F. Aprendizagem pianística na idade adulta: sonho ou realidade? 2004. Dissertação (Mestrado em Música) - Instituto de Artes, Universidade Estadual de Campinas, Campinas, 2004.

COUTTS, L. "I Should be Able to Play Already!" Promoting Self-Direction in Adult Piano Students through Transformational Learning Strategies. In: ANNUAL ADULT EDUCATION RESEARCH CONFERENCE, 56., 2015, Kansas. Proceedings...

Kansas: Kansas State University, 2015. p. 144-149. Disponível em:

<https://conferences.k-state.edu/adult-education/files/2015/02/AERC-

Proceedings_2015-oawrnt.pdf>. Acesso em: 10 maio 2015.

CREECH, A. et al. The power of music in the lives of older adults. Research Studies in Music Education, v. 35, n. 1, p. 87-10, 2013. Disponível em:

$<$ http://rsm.sagepub.com.ez67.periodicos.capes.gov.br/content/35/1/87>. Acesso em: 12 maio 2015.

CURY, V. H; THIELE, M. Tocar Piano 1 - Iniciação para adultos. São Paulo: Editora Musa, 1997.

DUARTE, R. Pesquisa qualitativa: reflexões sobre o trabalho de campo. Cadernos de Pesquisa, n. 115, p. 139-154, mar. 2002.

FABER, N.; FABER, R. Adult Piano Adventures - a comprehensive piano course. 2nd ed. USA: Faber Piano Adventures, 2009.

FERNANDES, T. M. A música em Ribeirão Preto - manifestações do começo do século XX. Ribeirão Preto: Fundação Instituto do Livro, 2011.

FERREIRA, A. B. H. Dicionário Eletrônico Aurélio Século XXI. Rio de Janeiro: Editora Nova Fronteira e Lexikon Informática, 1999. Versão 3.0. 1 CD-ROM.

GIL, A. C. Métodos e técnicas de pesquisa social. 5. ed. São Paulo: Atlas, 1999. 
GLASER, S.; FONTERRADA, M. Ensaio a respeito do ensino centrado no aluno: uma possibilidade de aplicação no ensino do piano. Revista da ABEM, n. 15, p. 1-9, set. 2006.

HADDAD, G. L.; FERRAZ, Jr. Jubileu de Brilhante: os 75 anos da Associação Musical de Ribeirão Preto. Ribeirão Preto: Editora Coruja, 2013.

HAMANN, D. L.; COOPER, S. C. Professional Knowledge: Teaching Music to Adult Leaners. In: Becoming a music teacher: from student to practitioner. USA: Oxford University Press, 2016. module. 31.

HENRIQUE, F. A. et al. Ontogenia: do nascimento à velhice. Revista de Psicofisiologia, 2005. Disponível em:

<www.icb.ufmg.br/lpf/revista/revista2/volume2_ontogenia.htm>. Acesso em: 14 mar. 2012.

HENTSCHKE, L. et al. Motivação para aprender música em espaços escolares e não escolares. Educação Temática Digital, Campinas, v. 10, p. 85-104, out. 2009. Número especial.

HOUAISS, A.; VILLAR, M. S. Minidicionário Houaiss da Língua Portuguesa. 4. ed. rev. e aumentada. Rio de Janeiro: Objetiva, 2010.

INSTITUTO Brasileiro de Geografia e Estatística. Disponível em: <http://www.ibge.gov.br/apps/populacao/projecao/>. Acesso em: 01 jun. 2016.

JACOBSON, J. M. Professional Piano Teaching: a comprehensive piano pedagogy textbook for teaching elementary-level students. Van Nuys: Alfred Publishing Co., 2006.

JUSTO, H. Você também é Diferente. Petrópolis: Editora Vozes Ltda, 1997

JUTRAS, P. J. The benefits of adult piano study as self-reported by selected adult piano studes. Journal of Research in Music Education, v. 54, n. 2, p. 97-110, 2006. Disponível em: <http://jrm.sagepub.com/content/54/2/97>. Acesso em: 08 jun. 2014.

KAPLAN, J. A. Teoria da aprendizagem pianística: uma abordagem psicológica. 3. ed. Porto Alegre: Movimento, 2008.

LIBÂNEO, J. Pedagogia e pedagogos, para quê? 7. ed. São Paulo: Cortez, 2004.

LUDOJOSKI, R. L. Andragogia o Educacion del Adulto. Buenos Aires: Editora Guadalupe, 1972.

MARCELLO, R. L. Iniciação de adultos ao piano: métodos brasileiros comercializados na cidade de São Paulo (SP). 2009. Trabalho de Conclusão de Curso (Licenciatura em Educação Musical) - Universidade Estadual Paulista "Júlio de Mesquita Filho", São Paulo, 2009. 
MARMIROLI, D. B. Música e emancipação feminina: os relatos de professoras de piano em Ribeirão Preto-SP (1970-2000). 2010. Trabalho de Conclusão de Curso (Graduação em História) - Centro Universitário Barão de Mauá, Ribeirão Preto, 2010.

MARTINS, H. H. T. S. Metodologia qualitativa de pesquisa. Educação e Pesquisa, São Paulo, v. 30, n. 2, p. 289-300, maio/ago. 2004.

MEDEIROS, F. G. T. O adulto fazendo música: uma nova abordagem na educação musical de adultos. Dissertação (Mestrado em Música) - Conservatório Brasileiro de Música, Rio de Janeiro, 1998.

MOURA, R. M. A vida adulta: uma visão dinâmica. Revista Inovação, 1999.

Disponível em: <http://rmoura.tripod.com/vidaadult.htm>. Acesso em: 14 mar. 2012.

MYERS, D. E. Teaching learners of all ages. Music Educators Journal. v. 79, n. 4, p. 23-26, dec. 1992.

ORGANIZAÇÃO DAS NAÇÕES UNIDAS PARA A EDUCAÇÃO, A CIÊNCIA E A CULTURA. Relatório Global sobre Aprendizagem e Educação de Adultos. Brasília: UNESCO, 2010.

Disponível em: <http://unesdoc.unesco.org/images/0018/001886/188644por.pdf>. Acesso em: 29 jul. 2015.

ORLOFKSY, D. D.; SMITH, R. Strategies for Adult Keyboard Learners. Music Educators Journal, v. 83, n. 4, p. 22-26, 1997. Disponível em:

<http://web.a.ebscohost.com.ez67. periodicos.capes.gov.br/ehost/detail/detail?sid=29 4b3aa8-319b-4bdf-b0c3-

d0208c8dea8d\%40sessionmgr4001\&vid=0\&hid $=4104 \&$ bdata $=J \mathrm{~m} \times \mathrm{hbmc} 9 \mathrm{cHQtYnImc}$ 210ZT1laG9zdC1saXZI\#\#db=afh\&AN=9701161766>. Acesso em: 15 maio 2015.

PACE, R. Music for Piano for the Older Beginner. New York: Lee Roberts Music Publications, Inc., 1967.

PAYNTER, J.; ASTON, P. Sound and Silence. 6th ed. Cambridge University, 1985.

PENNA, M. A função dos métodos e o papel do professor: em questão, "como" ensinar música. In: MATEIRO, T.; ILARI, B. (Org.). Pedagogias em Educação Musical. Curitiba: InterSaberes, 2012.

PERKINS, R.; AUFEGGER, L.; WILLIANOM, A. Learning through teaching: exploring what conservatoire students learn from teaching beginner older adults. International Journal of Music Education, v. 33, n. 1, p. 80-90, 2014. Disponível em: <http://ijm.sagepub.com/content/early/2014/05/12/0255761414531544>. Acesso em: 9 maio 2015.

RIBEIRO, R. J. Os principais ministérios: cultura. Valor Econômico, 01 dez. 2014. Disponível em: <http://www.valor.com.br/politica/3798846/os-principais-ministerioscultura>. Acesso: 29 mar. 2015. 
ROBINSON, H. Basic Piano for Adults. Belmont: Wadswoth Publishing Company, 1964.

ROULSTON, K.; JUTRAS, P.; KIM, S. J. Adult perspectives of learning musical instruments. International Journal of Music Education, p. 1-11, 2015. Disponível em:

<http://ijm.sagepub.com.ez67.periodicos.capes.gov.br/content/early/2015/05/02/0255 761415584291.full.pdf+html>. Acesso em: 14 maio 2015.

SAHR, H. The Adult Beginner. In: AGAY, D. The art of teaching piano. USA: Yorktown Music Press, 2004. p. 253-263.

SANTOS, A. M.; CORVISIER, F. M. Iniciação ao piano na fase adulta. In: CONGRESSO DA ASSOCIAÇÃO NACIONAL DE PESQUISA E PÓS-GRADUAÇÃO EM MÚSICA, 22., 2012, João Pessoa. Anais... João Pessoa: ANPPOM, 2012, p. 1131-1137. Disponível em: <http://www.anppom.com.br/anais/anaiscongresso_anppom_2012/Anais_ANPPOM_ 2012.pdf>. Acesso em: 20 out. 2014.

SCHMIDT, S. W. The Future of Adult Education. Adult Learning, v. 24, n. 2, p. 7981, abr. 2013. Disponível em:

$<$ http://alx.sagepub.com.ez67.periodicos.capes.gov.br/content/24/2/79 >. Acesso em: 8 set. 2014.

SCHOEN, G. Upper Hands - a method for adults 50+. USA: Upper Hands Productions, 2012.

STATERI, J. Curso do Pianista Moderno. São Paulo: Redijo, 1978.

Piano Moderno. São Paulo: Casa Vivaldi, 1988.

Reflexões sobre o ensino do piano para adultos e adolescentes.

Osasco: Fundação Instituto Tecnológico de Osasco (FITO), 1996.

. Reflexões e práticas sobre uma filosofia da pedagogia musical.

Indaiatuba: Edição Didática Independente, 2014.

TAYLOR, A. Older amateur keyboard players learning for self-fulfilment. Psychology of Music, v. 39, n. 3, p. 345-363, jul. 2011. Disponível em:

$<$ http://pom.sagepub.com.ez67.periodicos.capes.gov.br/content/39/3/345>. Acesso em: 12 maio 2015.

THOMPSON, J. Adult Piano Course. USA: The Willis Music Co., 1943.

TOMANIK, A. M. Um olhar sobre o ensino de piano para adultos. 2011.

Dissertação (Mestrado em Música) - Universidade Federal de Minas Gerais, Belo Horizonte, 2011. Disponível em:

$<$ http://www.bibliotecadigital.ufmg.br/dspace/bitstream/handle/1843/AAGS-

8U4H6S/disserta_o__aline_maria_tomanik.pdf?sequence=1 >. Acesso em: 30 jul. 2014. 
USZLER, M., GORDON, S.; SMITH, S. M. The well-tempered keyboard teacher. 2nd ed. USA: Schimer Books, 2000.

USZLER M. The adult student. In : USZLER, M.; GORDON, S.; SMITH, S. M. The well-tempered keyboard teacher. 2nd ed. USA: Schimer Books, 2000. cap. 3, p. 55-77.

WRISTEN, B. Demographics and motivation of adult group piano students. Music Education Research, v. 8, n. 3, p. 387-406, 2006. Disponível em: <http://web.a.ebscohost.com.ez67.periodicos.capes.gov.br/ehost/detail/detail?sid=e2 2cb3a5-f0c9-43a6-b745-

08b3d043b23b\%40sessionmgr4002\&vid=0\&hid $=4104 \&$ bdata $=J \mathrm{~m} \times \mathrm{hbmc} 9 \mathrm{cHQtYnImc}$ 210ZT1laG9zdC1saXZl\#\#db=afh\&AN=22493902>. Acesso em: 12 maio 2015. 


\section{APÊNDICES}

\section{APÊNDICE A - Questões: Aluno Adulto}

\section{Nome:}

- Idade:

- Sexo:
( ) Masculino
( ) Feminino

- Exerce alguma profissão?
( ) Sim
( ) Não
( ) Aposentado

Se sim, qual é a sua profissão?

- Qual é o seu nível de escolaridade?

Ensino Fundamental

Ensino Médio ( ) completo ( ) incompleto

Superior

( ) completo

( ) incompleto

Pós-Graduação

( ) completo

( ) incompleto

- Que tipo de música você gosta?

\section{I - Trajetória Musical}

- Quando foi o seu primeiro contato com o piano?

- Tem alguém na família que toca algum instrumento?
( ) Sim
( ) Não

Se sim, especifique o instrumento:

- Há quanto tempo você tem aulas de piano como um aluno adulto?

- Em qual espaço ocorrem suas aulas de piano?

( ) Casa do Professor ( ) Escola de Música ( ) Conservatório de Música ( ) Outros - Especifique:

- Você tem aulas de piano:
( ) em grupo
( ) individual

- Além da aula de piano, você tem outras aulas de música, por exemplo: teoria, coral, prática de conjunto?
( ) Sim
( ) Não

Se sim, especifique: 


\section{II - Razões para iniciar o estudo de piano na fase adulta}

- Qual a sua principal motivação para iniciar uma atividade musical nesta fase da vida?

- Quais suas expectativas com a aprendizagem de um instrumento na fase adulta?

\section{III - Descrição das Práticas Docentes para o Aluno Adulto Iniciante de Piano}

- Como é definido o programa (métodos, peças, etc.) do seu curso de piano?

- Cite os tipos de materiais (métodos/livros, partituras) que você usa em suas aulas.

- Há algum método que você estuda que contém no título a palavra "adulto"? (Método de piano específico para o aluno adulto)

( ) Sim ( ) Não

Se sim, especifique:

- Que tipo de repertório você estuda nas aulas?

- Quais atividades você realiza nas aulas de piano? (Ex.: exercícios, métodos, peças avulsas)

- Você tem atividades de criação musical em sua aula de piano? (Ex.: improvisar, criar música, etc)

( ) Sim ( ) Não

Se sim, especifique:

- Você toca música de "ouvido" (tocar uma música que você ouviu, sem ler a partitura)?

- Como o professor de piano apresenta os conteúdos em aula?

\section{IV - Experiências de Adultos na Iniciação Pianística}

- Quais são os elementos favoravéis que encontra na aprendizagem do piano na fase adulta?

- Quais são as dificuldades que encontra na aprendizagem do piano na fase adulta? 


\section{APÊNDICE B - Questões: Professores}

Nome:

Idade:

Nível de Escolaridade:

\section{I - Trajetória Musical}

- Descreva o percurso de sua formação pianística e da prática docente (desde a iniciação ao piano até a formação profissional).

- Desde quando você atua na prática docente no contexto do ensino de piano?

- Em qual espaço e contexto (aulas particulares, escola de música, conservatório) você atua como professor de piano para alunos adultos iniciantes?

- Qual é a faixa etária de seus alunos?

- Quais outras atividades musicais que você realiza como professor?

\section{II - Razões para iniciar o estudo de piano na fase adulta}

- Quais são as motivações de seus alunos adultos quanto ao estudo do piano nessa fase da vida?

- Quais são as expectativas que seus alunos adultos apresentam quanto à aprendizagem do piano nessa fase da vida?

\section{III - Descrição das Práticas Docentes para o Aluno Adulto Iniciante de Piano}

- Como é definido o programa (conteúdo) do curso de piano para o aluno adulto?

- Você considera que há diferenças entre o programa de ensino desenvolvido em aulas particulares, escolas de música e/ou conservatório? Aponte as diferenças.

- Quais os materiais didáticos (métodos, livros, partituras) que você utiliza com adultos iniciantes?

- Utiliza métodos específicos para adultos? Quais?

- Que tipo de repertório é realizado em sala de aula?

- Como é feita a escolha do repertório?

- Você desenvolve atividades de criação musical nas aulas? Se sim, especifique a (s) atividade (s).

- Como são os seus modos de ensinar para alunos adultos iniciantes? 


\section{IV - Experiências de Adultos na Iniciação Pianística}

- Quais aspectos mais favoráveis da aprendizagem pianística para adultos iniciantes?

- Quais são as dificuldades da aprendizagem pianística para adultos iniciantes? 


\section{APÊNDICE C - Termo de Consentimento Livre e Esclarecido}

As informações a seguir descreverão o papel que você terá como participante. O pesquisador responsável responderá a quaisquer dúvidas que você possa ter sobre este termo de consentimento e sobre o estudo. Por favor, leia-o cuidadosamente:

Este estudo é um projeto de pesquisa de mestrado que estamos realizando junto ao Programa de Pós-Graduação em Música pela Escola de Comunicação e Artes da USP/SP sob a orientação do Prof. Dr. Marcos Câmara de Castro, professor do Departamento de Música da FFCLRP.

Esta pesquisa tem por objetivo promover um estudo acerca dos processos de ensino e aprendizagem de música na fase adulta na atualidade, analisando os modos de ensino de professores que atuam no ensino de piano e para adultos iniciantes com a idade entre 30 a 59 anos, em aulas particulares, escolas de cursos livres de música e conservatórios de Ribeirão Preto. A partir dos objetivos desse estudo, serão convidados a participar dessa pesquisa professores e alunos adultos de piano.

O ensino de música para adultos vem ganhando cada vez mais espaço. Vários autores têm estudado sobre a iniciação musical na infância, no entanto, quando se trata sobre a aprendizagem musical na fase adulta, principalmente no Brasil, a quantidade de trabalhos ainda é reduzida. Como resultado, espera-se que este trabalho contribua para o desenvolvimento de propostas significativas de ensino para adultos iniciantes no piano, favoreça a reflexão da prática docente e ainda forneça elementos de interesse àqueles que desejam atuar no ensino de música para adultos.

Caso aceite participar deste estudo, você participará de uma entrevista semiestruturada que será gravada e transcrita posteriormente pela pesquisadora.

Sua participação será voluntária e não implicará em nenhum ônus ou remuneração. Serão obedecidos os referenciais básicos de pesquisa em seres humanos, conforme preconiza a resolução 466/12 do Conselho Nacional de Saúde.

Caso deseje participar desta pesquisa, não haverá nenhum risco ou dano a você.

Todas as informações obtidas em relação a este estudo permanecerão em sigilo, assegurando proteção da sua imagem e respeitando valores morais, culturais, 
religiosos, sociais e éticos. Como condição da sua participação na pesquisa, você permitirá à pesquisadora a coleta de informações necessárias para o estudo. Os resultados desta pesquisa poderão ser apresentados em congressos, publicações, porém, a sua identidade não será divulgada nestas apresentações, nem serão utilizadas quaisquer imagens ou informações que permitam a sua identificação.

Em caso de dúvidas sobre o estudo, você poderá receber mais esclarecimentos com a pesquisadora pelo telefone: (16) 9 9211-9349 ou ainda por email: adriana.moraes.santos@usp.br.

A qualquer momento, você poderá se retirar desta pesquisa.

Após estes esclarecimentos, caso aceite participar desta pesquisa, solicitamos que assine este documento impresso em duas vias, sendo uma via para o entrevistado e a outra para a pesquisadora.

Ribeirão Preto, de de

Assinatura:

Telefone:

E-mail: 